\title{
Fluorine-Containing Diazines in Medicinal Chemistry and Agrochemistry
}

\author{
Dmitriy M. Volochnyuk, Oleksandr O. Grygorenko, and Alina O. Gorlova
}

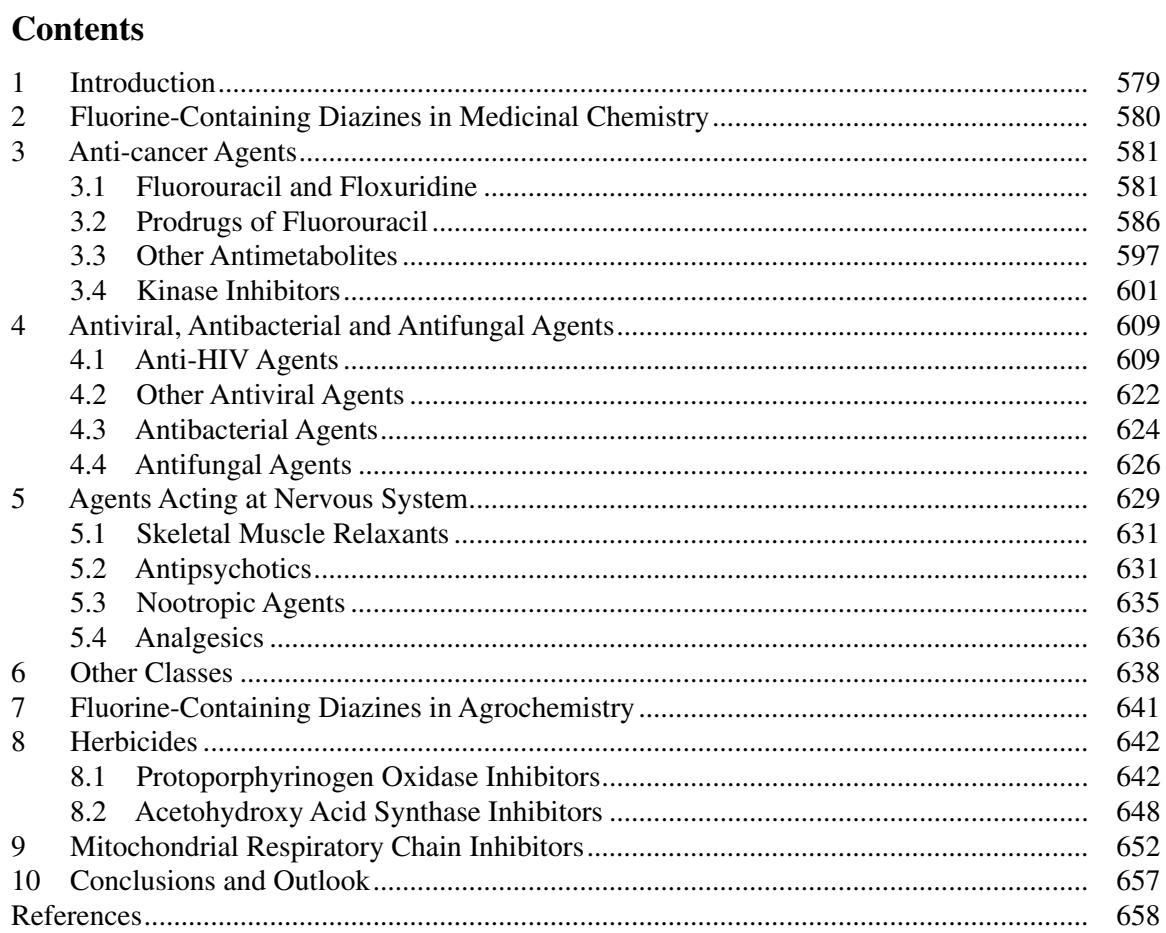

D.M. Volochnyuk $(\varangle) \bullet$ A.O. Gorlova

Biologically Active Compound Department, Institute of Organic

Chemistry, National Academy of Sciences of Ukraine,

Murmanska Street 5, Kyiv 02660, Ukraine

e-mail: d.volochnyuk@gmail.com

O.O. Grygorenko

Department of Chemistry, National Taras Shevchenko University of Kyiv,

Volodymyrska Street, 64, Kyiv 01601, Ukraine 


\begin{abstract}
The combination of a fluorine atom and a diazine ring, which both possess unique structural and chemical features, can generate new relevant building blocks for the discovery of efficient fluorinated biologically active agents. Herein we give a comprehensive review on the biological activity and synthesis of fluorine containing, pyrimidine, pyrazine and pyridazine derivatives with relevance to medicinal and agrochemistry.
\end{abstract}

Keywords Pyrimidine $\bullet$ Pyrazine $\bullet$ Pyridazine $\bullet$ Fluorine $\bullet$ Bioactive compounds $\bullet$ Medicinal chemistry $\bullet$ Agrochemistry

\title{
Abbreviations
}

$\begin{array}{ll}\text { AHAS } & \text { acetohydroxy acid synthase } \\ \text { ATP } & \text { adenosine triphosphate } \\ \text { B }_{2}(\text { Pin })_{2} & \text { Bis(pinacolato)diboron } \\ \text { BCR } & \text { B-cell receptor } \\ \text { Boc } & \text { tert-butoxycarbonyl } \\ \text { BOP } & \text { benzotriazol-1-yloxy-tris(dimethylamino)-phosphonium } \\ & \text { hexafluorophosphate } \\ \text { Bu } & \text { Butyl } \\ \text { CDK } & \text { cyclin-dependent kinase } \\ \text { CDMT } & \text { 2-chloro-4,6-dimethoxy-1,3,5-triazine } \\ \text { CLL } & \text { chronic lymphocytic leukemia } \\ \text { CNS } & \text { central nervous system } \\ \text { CSA } & \text { camphorsulfonic acid } \\ \text { CyJohnPhos } & \text { 2-(dicylohexyl-phosphino)biphenyl } \\ \text { DAST } & \text { diethylaminosulfur trifluoride } \\ \text { Dba } & \text { Dibenzylideneacetone } \\ \text { DHFU } & \text { Dihydrofluorouracil } \\ \text { DIC } & \text { diisopropyl carbodiimide } \\ \text { DIBAL } & \text { diisobutylaluminium hydride } \\ \text { DIPEA } & \text { ethyl diisopropyl amine } \\ \text { DMF } & \text { Dimethylformamide } \\ \text { DMSO } & \text { dimethyl sulfoxide } \\ \text { DNA } & \text { deoxyribonucleic acid } \\ \text { dppe } & \text { bis(diphenylphosphino)ethane } \\ \text { Dppf } & \text { 1,1'-bis(diphenylphosphino)pherocene } \\ \text { DPP-4 } & \text { dipeptidyl peptidase } \\ \text { dTMP } & \text { deoxythymidine monophosphate } \\ \text { dUMP } & \text { deoxyuridine monophosphate } \\ \text { EPA } & \text { environmental protection agency } \\ \text { FDA } & \text { Food and Drug Administration } \\ \text { FdUDP } & \text { fluorodeoxyuridine diphosphate } \\ & \end{array}$




$\begin{array}{ll}\text { FdUMP } & \text { fluorodeoxyuridine monophosphate } \\ \text { FdUTP } & \text { fluorodeoxyuridine triphosphate } \\ \text { FMDV } & \text { foot-and-mouth disease virus } \\ \text { FUDP } & \text { fluorouridine diphosphate } \\ \text { FUDR } & \text { Floxuridine } \\ \text { FUMP } & \text { fluorouridine monophosphate } \\ \text { FUR } & \text { Fluorouridine } \\ \text { FUTP } & \text { fluorouridine triphosphate } \\ \text { EDC } & \text { 1-ethyl-3-(3-dimethylaminopropyl)carbodiimide } \\ \text { GIP } & \text { gastric inhibitory peptide } \\ \text { GLP-1 } & \text { glucagon-like peptide-1 } \\ \text { HIV } & \text { Human immunodeficiency virus } \\ \text { HOBT } & \text { Hydroxybenzotriazole } \\ \text { HPLC } & \text { high-performance liquid chromatography } \\ \text { JAK } & \text { Janus kinase } \\ \text { JAK-STAT } & \text { Janus kinase - signal transducer and activator of transcription } \\ \text { L-DOPA } & \text { L-3,4-dihydroxyphenylalanine } \\ \text { Me } & \text { Methyl } \\ \text { NADH } & \text { Nicotinamide adenine dinucleotide } \\ \text { NMM } & \text { N-methylmorpholine } \\ \text { PDC } & \text { pyridinium dichromate } \\ \text { Ph } & \text { Phenyl } \\ \text { py } & \text { Pyridine } \\ \text { RNA } & \text { ribonucleic acid } \\ \text { (S,S)-Et-DuPhos } & 1,2 \text {-bis[(2S,5S)-2,5-diethylphospholano]benzene } \\ \text { TBAF } & \text { tetra-n-butylammonium fluoride } \\ \text { TBDPS } & \text { tert-butyl diphenyl silyl } \\ \text { TFA } & \text { trifluoroacetic acid } \\ \text { TMSNCO } & \text { Trimethylsilylisocyanate } \\ \text { TMSO } & \text { Tetramethylenesulfoxide } \\ \text { TMSOTf } & \text { trimethylsilyl trifluoromethanesulfonate } \\ \text { WNV } & \text { West Nile virus } \\ \text { XantPhos } & \text { 4,5-bis(diphenylphosphino)-9,9-dimethylxanthene } \\ \text { YFV } & \text { yellow fever virus } \\ & \end{array}$

\section{Introduction}

Diazines are aromatic six-membered heterocycles that contain two $\mathrm{sp}^{2}$-hybridized nitrogen atoms in the ring. The three diazine isomers are pyridazine (1,2-diazine), pyrimidine (1,3-diazine) and pyrazine (1,4-diazine). The most important naturally occurring diazines are the pyrimidine bases uracil, thymine, and cytosine, which comprise the fundamental nucleoside building blocks in deoxyribonucleic acid (DNA) and ribonucleic acid (RNA). Pyrazines occur frequently as 
constituents in foodstuffs and are responsible for their flavor and strong aroma. Although being present in very small amounts, they are highly odiferous and can be detected at extremely low concentrations. Unlike other heterocycles found in many important natural products, pyridazines were discovered only after 1970, and relatively few pyridazines have thus far been isolated from natural sources. As synthetic compounds, all diazines constitute an important pharmacophoric moiety present in many drugs acting on various pharmacological targets as well as agrochemicals.

Inspite of organofluorine compounds are almost absent as natural products, $\sim 25 \%$ of drugs in the pharmaceutical pipeline and $\sim 15 \%$ of agrochemicals contain at least one fluorine atom. One of the earliest synthetic fluorinated drugs is the antineoplastic agent 5-fluorouracil, derivative of pyrimidine, an antimetabolite first synthesised in 1957. Since the advent of 5-fluorouracil, fluorine substitution is commonly used in contemporary medicinal and agrochemistry to improve metabolic stability, bioavailability and protein-ligand interactions. In this review only compound bearing fluoro or fluoroalkyl substituent in diazine ring are discussed. Among fluorine containing diazines now 12 drugs and 10 agrochemicals are presented on the market. This review provides an information about fluorinated diazines as drugs or agrochemicals and their mode of action as well as synthesis. The review is divided in two parts. First part dedicated to the medicinal and synthetic chemistry of fluorinated diazines that have reached at least clinical development phase. The second one dedicated to the biological role and the chemistry of the marketed agrochemicals based on fluorinated diazines.

\section{Fluorine-Containing Diazines in Medicinal Chemistry}

It is widely accepted that compounds containing fluorine atoms have a remarkable record in medicinal chemistry and play a continuing role in providing lead compounds for potential therapeutic applications. The reasons for that have been discussed extensively in a number of books and reviews [1, 2]. In this view, fluorine-containing diazines are not the exception; they have attracted attention of medicinal chemists since 1950s when Fluorouracil (1) was introduces as anti-cancer drug. Analysis of MDDR (MDL Drug Data Report) data retrieved 1,150 hits derived from fluorine-containing diazines [3]. Nearly a third part of them is represented by anti-cancer agents (Fig. 1); other important classes (more than 100 examples) include compounds with antiviral (mainly anti-HIV) and antiarthritic activity.

According to MDDR, 106 compounds containing a fluorinated diazine moiety have entered pre-clinical studies, 40 of them have reached clinical phase, and 12 of these have become drug substances (Fig. 2). In the following sections, fluorinecontaining diazine derivatives that have reached at least clinical development phase will be discussed, focusing on their aspects related to medicinal and synthetic organic chemistry. 


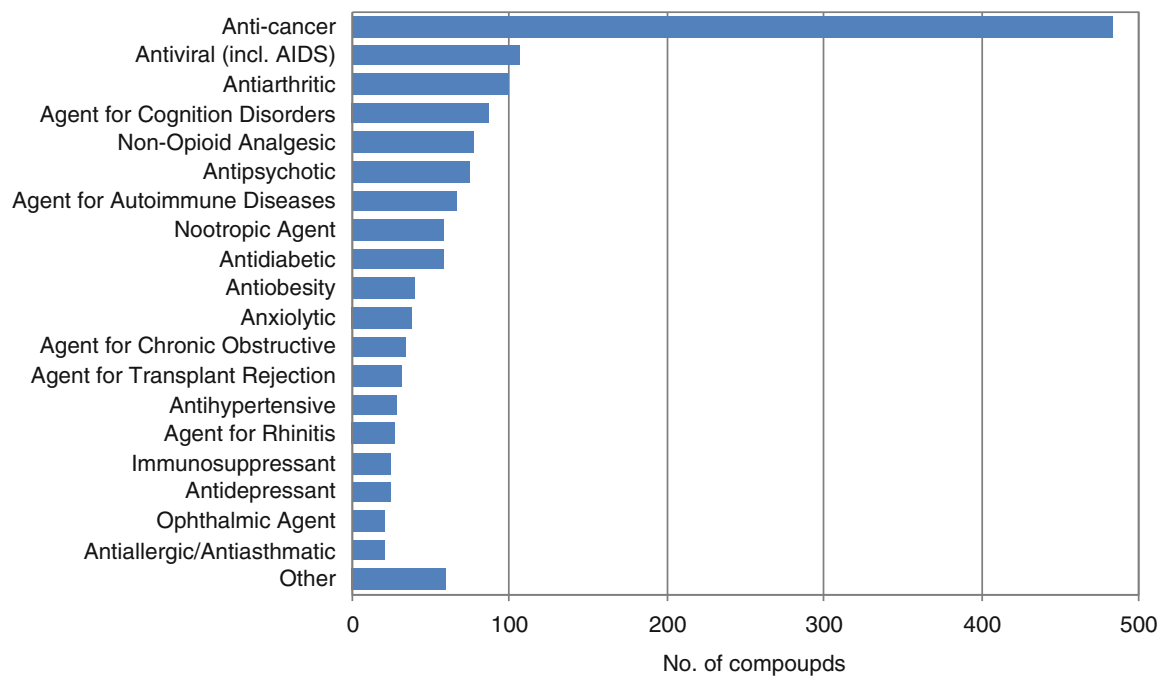

Fig. 1 Distribution of biological activity for fluorine-containing diazines in MDDR

\section{Anti-cancer Agents}

\subsection{Fluorouracil and Floxuridine}

The use of fluorinated diazines as anti-cancer agents is the major field of their application in medicinal chemistry. The first representative of this class, Fluorouracil (1) was developed by Charles Heidelberger and co-workers in 1957 [4]. It was approved by U.S. FDA [5] in 1962 as antineoplastic agent in the treatment of advanced colorectal cancer. Fluorouracil represents a class of rationally designed anticancer agents which act as antimetabolites. The observation that rat hepatomas utilized radiolabeled uracil more avidly than normal tissues [6] implied that the enzymatic pathways for utilization of uracil or its close analogs differed between malignant and normal cells - a feature which might provide a target for antimetabolite chemotherapy. A minimal modification of uracil by introducing a single fluorine atom allowed for implementation of cellular uptake and metabolic activation of $\mathbf{1}$ via the same transport processes and enzymes involved in the case of uracil. However, in the case of essential biological targets, remarkable differences are observed due to unique properties of the fluorine atoms, which result in inhibition of the metabolic and signal pathways involved. Although all the details of the mechanism by which Fluorouracil gives its biological effect are not elucidated, a remarkable progress has been made over the past half a century in elucidating its cellular and clinical pharmacology $[7,8]$. 
<smiles>O=c1[nH]cc(F)c(=O)[nH]1</smiles>

Fluorouracil (1)<smiles>CCCCCCNC(=O)n1cc(F)c(=O)[nH]c1=O</smiles>

Carmofur (2)<smiles>O=c1[nH]c(=O)n(C2CCCO2)cc1F</smiles>

Tegafur (3)<smiles>O=c1[nH]c(=O)n([C@H]2C[C@H](O)C(CO)O2)cc1F</smiles>

Floxuridine (4)<smiles>CC1O[C@@H](n2cc(F)c(=O)[nH]c2=O)[C@H](O)[C@@H]1O</smiles>

Doxifluridine (5)<smiles>CCCCCOC(=O)Nc1nc(=O)n([C@@H]2O[C@H](C)[C@@H](O)[C@H]2O)cc1F</smiles>

Capecitabine (6)

\section{Other drugs}<smiles>O=c1[nH]c(=O)n(C2C[C@@H](O)C(CO)O2)cc1C(F)(F)F</smiles>

Trifluridine (7) Antiviral<smiles>Nc1nc(=O)n([C@H]2CS[C@@H](CO)O2)cc1F</smiles>

Emtricitabine (8) Anti-HIV<smiles>Cc1ccccc1-n1c(CF)nc2ccc(N)cc2c1=O</smiles>

Afloqualone (11)

Skeletal muscle relaxant<smiles>Nc1nc(=O)[nH]cc1F</smiles>

Flucytosine (9) Antifungal<smiles>CC(c1ncncc1F)[C@H](O)Cn1cncn1</smiles>

Voriconazole (10) Antifungal<smiles>N[C@@H](CC(=O)N1CCc2c(nc(C(F)(F)F)nc2C(F)(F)F)C1)CN1CC(F)(F)CCC1=O</smiles>

Fig. 2 Drug substances derived from fluorine-containing diazines

The key steps in Fluorouracil metabolism are shown in Scheme 1. Up to $80 \%$ of $\mathbf{1}$ administered as injection is transformed to dihydrofluorouracil (DHFU, 13) by dihydropyrimidine dihydrogenase (mostly in liver tissues). However, this metabolite is not involved into antineoplastic activity; instead, 13 itself and its further metabolites are responsible for most of the toxic effects of $\mathbf{1}$. The main mechanism of activation of Fluorouracil is conversion to fluorouridine monophosphate (FUMP, 14), either directly by orotate phosphoribosyltransferase, or via fluorouridine (FUR, 15) through the sequential action of uridine phosphorylase and uridine kinase. 14 is then phosphorylated to give fluorouridine diphosphate (FUDP, 16), which can be either phosphorylated again to the active metabolite fluorouridine triphosphate (FUTP, 19), or reduced to fluorodeoxyuridine diphosphate (FdUDP, 18) by ribonucleotide reductase. In turn, $\mathbf{1 8}$ can either be dephosphorylated or phosphorylated to generate 
the active metabolites fluorodeoxyuridine monophosphate (FdUMP, 19) and fluorodeoxyuridine triphosphate (FdUTP, 19), respectively.

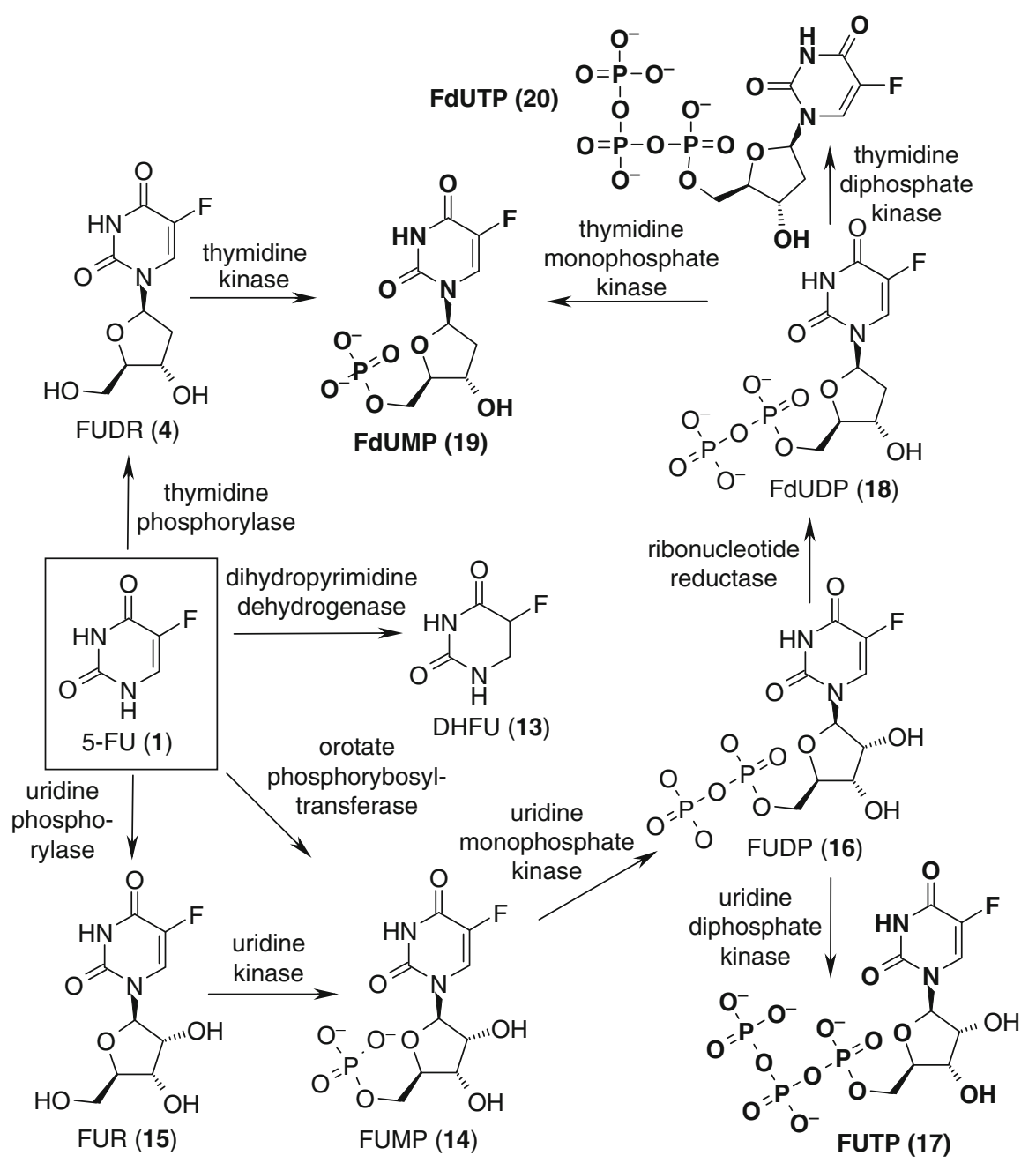

Scheme 1 Metabolism of Fluorouracil (active metabolites are shown in bold)

An alternative activation pathway involves the thymidine phosphorylase catalysed conversion of $\mathbf{1}$ to Floxuridine (FUDR, 4), which is then phosphorylated by thymidine kinase to give 19. The metabolite of $\mathbf{1}$-Floxuridine - is itself used as an anti-cancer agent [9]. It was launched in 1970 by Hospira Inc [5]. Upon rapid injection, most of Floxuridine is catabolized to Fluorouracil; hence similar effects on the organism are obtained in this case. On the contrary, when $\mathbf{4}$ is slowly administered into the arterial blood, it is mostly transformed to 19; thus toxic effects are diminished comparing to $\mathbf{1}$ [10].

It has long been recognized that one of the main mechanisms underlying Fluorouracil action is inhibition of thymidylate synthase by fluorodeoxyuridine monophosphate 
(19) [11]. Thymidylate synthase belongs to a class of enzymes required for DNA replication, and its activity is higher in rapidly proliferating cells. In particular, thymidylate synthase is responsible for methylation of deoxyuridine monophosphate (dUMP, 21) to deoxythymidine monophosphate (dTMP, 22) with the use of 5,10-methylenetetrahydrofolate (23) as a cofactor (Scheme 2) [12]. With fluorodeoxyuridine monophosphate, a slowly-reversible ternary complex $\mathbf{2 4}$ is formed instead. Inhibition of thymidylate synthase leads to deoxyribonucleotide imbalance, and hence to interference with DNA synthesis and repair. Alternative mechanism of DNA-directed Fluorouracil effect is misincorporation of fluorodeoxyuridine triphosphate (20) into DNA. Analogously, fluorouridine triphosphate (17) is extensively incorporated into different RNA species, disrupting their normal processing and function $[7,8,11]$.

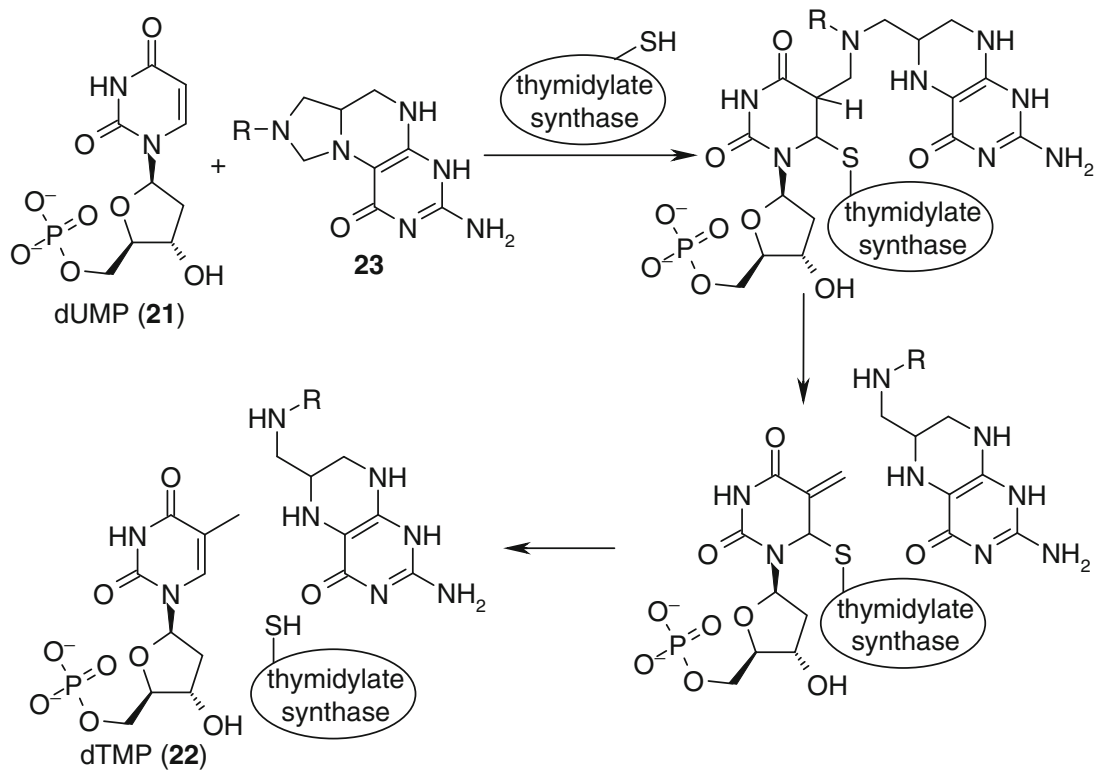

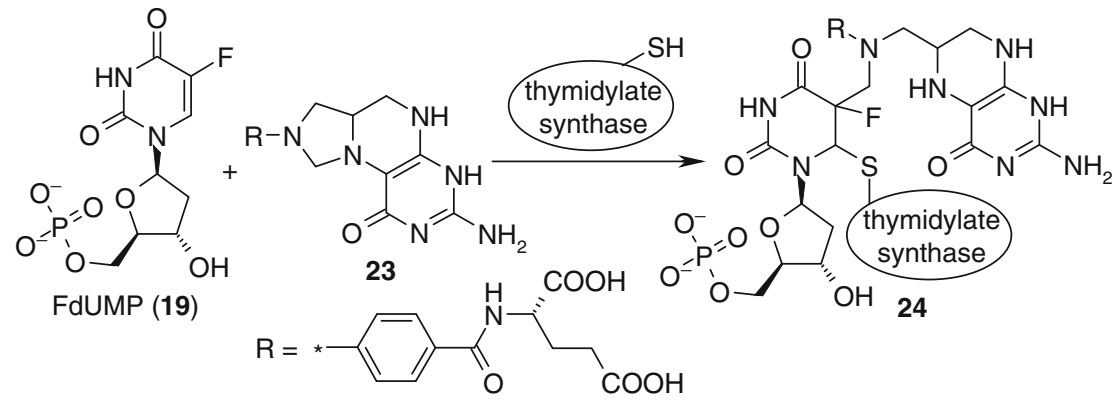

Scheme 2 Thymidylate synthase inhibition by fluorodeoxyuridine monophosphate (19)

Two principal approaches were used for the preparation of Fluorouracil (Scheme 3). One of the first methods $[13,14]$ commenced from ethyl fluoroacetate which was subjected to Claisen condensation with ethyl formate to give $\mathbf{2 5}$. The salt $\mathbf{2 5}$ was 
introduced into reaction with $S$-alkylisothiourea to give fluoropyrimidines $\mathbf{2 6}$, which were hydrolysed to give $\mathbf{1}$. Several variations of this method were also described; their common drawback was the use of highly toxic fluoroacetic acid derivatives.

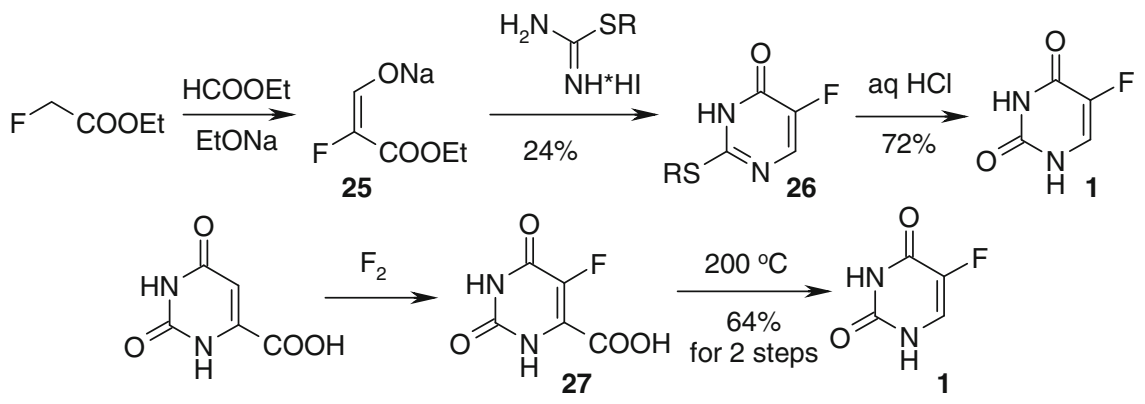

Scheme 3 Syntheses of Fluorouracil (1)

In an alternative approach, Fluorouracil was prepared by direct fluorination of different pyrimidine derivatives, including uracil [15], cytosine [16], and orotic acid [17]. In the latter method, the initially obtained fluoroorotic acid $\mathbf{2 7}$ was subjected to decarboxylation. The use of two-step reaction sequence was claimed to be advantageous due to simplified product isolation and purification.

Early synthesis of Floxuridine commenced from Fluorouracil (1) which was transformed into its mercury salt $\mathbf{2 8}$ and then allowed to react with 2-deoxy-Dribofuranosyl chloride derivative $\mathbf{2 9}$ (Scheme 4) [18]. The product $\mathbf{3 0}$ was subjected to alkaline hydrolysis to give Floxuridine (4).

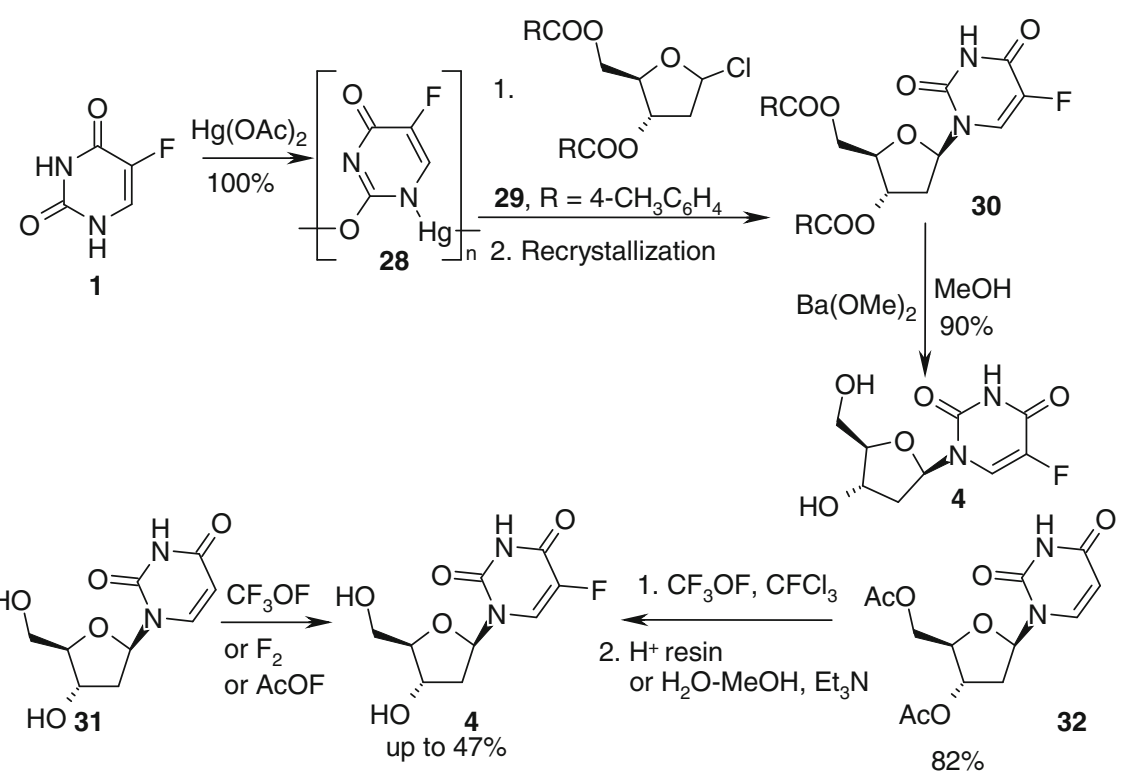

Scheme 4 Syntheses of Floxuridine (4) 
As in the case of Fluorouracil, newer syntheses of Floxuridine relied on direct fluorination of uracil derivatives. Fluorination of uridine $\mathbf{3 1}$ was done using fluorine [19], acetyl fluoride [20], and $\mathrm{CF}_{3} \mathrm{OF}$ [21]. The latter reagent gave good but still moderate yield of the product 4 (47\%). The use of a two-step reaction sequence, i.e. fluorination of diacetoxy derivative $\mathbf{3 2}$ and hydrolysis, improved the yield of $\mathbf{4}$ to $82 \%$ over two steps $[21,22]$.

\subsection{Prodrugs of Fluorouracil}

Despite Fluorouracil remains the main agent for the treatment of certain cancer types (i.e. colorectal) [23], it displays various side effects due to its nonspecific cytotoxicity, poor distribution to tumor sites, and serious limitations in effectiveness due to drug resistance. Apart from modulation of Fluorouracil biological action through combination therapies [7, 24], a number of drugs and clinical candidates acting as prodrugs of $\mathbf{1}$ and/or $\mathbf{4}$ were developed (Table 1).

Table 1 Fluorouracil/Floxuridine prodrugs [3, 5]

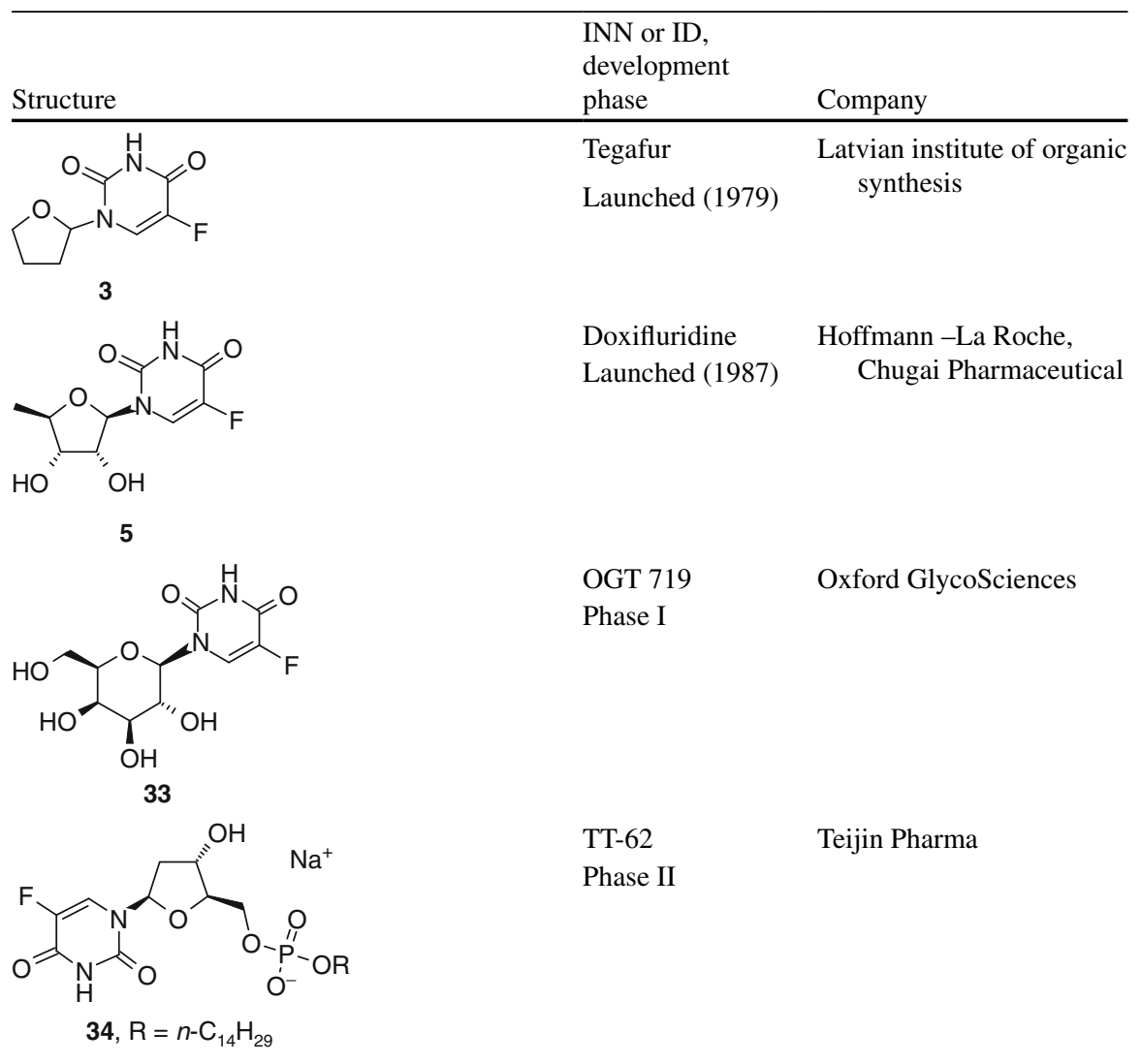


Table 1 (continued)

\begin{tabular}{lll}
\hline & $\begin{array}{l}\text { INN or ID, } \\
\text { development } \\
\text { phase }\end{array}$ & Company \\
\hline Structure & $\begin{array}{l}\text { T-506 } \\
\text { Phase II }\end{array}$ & Toyama Chemical \\
& &
\end{tabular}

35, $R=(Z)$-pentadec-7-en-1-yl<smiles>CCCCCCNC(=O)n1cc(F)c(=O)[nH]c1=O</smiles>
Carmofur
Launched (1981)
Yamanouchi
Pharmaceutical, Mitsui Chemicals

Atofluding

Phase III

Xian Lijun Pharmaceutical<smiles>CC(=O)n1cc(F)c(=O)n(C(=O)c2ccccc2C)c1=O</smiles>

36<smiles></smiles>

Emitefur, BOF-2A Otsuka Pharmaceutical Phase III

5-FP

Phase I

Capecitabine

Launched (1998)

Galocitabine

Phase II
Astex Pharmaceuticals, Yale University

Hoffman La Roche

Hoffman La Roche<smiles>COc1cc(C(=O)Nc2nc(=O)n([C@@H]3O[C@H](C)[C@@H](O)[C@H]3O)cc2F)cc(OC)c1OC</smiles> 
The first example of Fluorouracil prodrug is Tegafur (3) developed in 1960s in Latvia [25, 26]. Tegafur is an oral slow-release prodrug formulation of Fluorouracil which is readily absorbed through the gastrointestinal tract. The major pathway of metabolic activation of $\mathbf{3}$ includes hydroxylation by hepatic cytochrome P450 enzymes, mostly CYP2A6 (Scheme 5) [27].

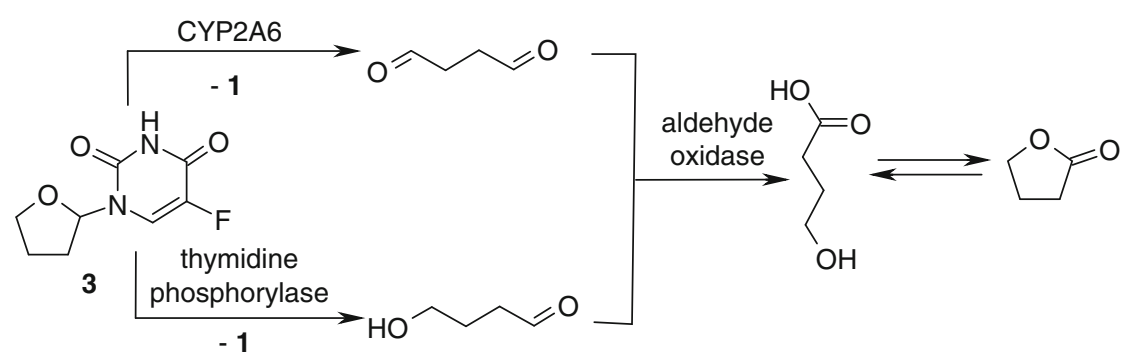

Scheme 5 Metabolic activation of Tegafur (3)

Apart from Fluorouracil, 4-hydrohybutyraldehyde and succinic dialdehyde are also formed, which are further transformed into $\gamma$-butyrolactone and 4-hydrohybutyric acid [28]. Tegafur was shown to be 2-5 times more potent and less toxic than 1; hence lower doses of $\mathbf{3}$ can be utilized, resulting in decreased neurotoxicity without compromising the antitumor effects.

Another prodrug of Fluorouracil - Doxifluridine (5), which also implies the idea of attachment of sugar-like moiety to the molecule of $\mathbf{1}$, was launched in Japan in 1987 [29]. The mechanism of metabolic activation of $\mathbf{5}$ is rather simple and includes hydrolysis to Fluorouracil by thymidine phosphorylase [299]. Since the level of thymidine phosphorylase is significantly higher in several types of solid tumours (in particular, colorectal, breast, and kidney cancers) as compared with normal tissues, Doxifluridine possesses a higher therapeutic index for these types of cancers. The use of $\mathbf{5}$ is somewhat limited by gastrointestinal toxicity after oral administration due to release of $\mathbf{1}$ by intestinal pyrimidine nucleoside phosphorylase [30].

Yet another sugar-modified Fluorouracil derivative - OGT 719 (33), in which galactose is incorporated onto the fluoropyrimidine moiety, was developed by Oxford GlycoSciences and had reached Phase I clinical study [31]. In 1999, the company decided to discontinue development of $\mathbf{3 3}$ as the results of Phase I/II clinical study were not sufficiently strong to justify large scale Phase II studies. OGT 719 was rationally designed to reduce the systemic toxicity normally associated with Fluorouracil while retaining activity against tumors localized in the liver, in which it may be preferentially localized through the asialoglycoprotein receptors [32]. These receptors are present on the surface of hepatocytes and recognise various sugar-containing biomolecules through terminal galactose and $\mathrm{N}$-acetylgalactosamine residues. The metabolic activation of OGT 719 occurs once the compound enters hepatocytes, where the galactose molecule is cleaved from the Fluorouracil residue. 
<smiles>O=C(O)CCCCCNC(=O)n1cc(F)c(=O)[nH]c1=O</smiles>

40<smiles>CC(O)CCCCNC(=O)n1cc(F)c(=O)[nH]c1=O</smiles>

42<smiles>O=C(O)CCCNC(=O)n1cc(F)c(=O)[nH]c1=O</smiles>

41<smiles>CC(=O)CCCCNC(=O)n1cc(F)c(=O)[nH]c1=O</smiles>

43

Fig. 3 Metabolites of Carmofur (2)

Two derivatives of Floxuridine - TT-62 (34) and T-506 (35) have reached Phase II clinical trials in Japan [3]. The compounds showed significant antitumor activity by oral administration; moreover, they slowly released Floxuridine, and the effective level of $\mathbf{4}$ was prolonged [33, 34]. The gastro-intestinal disturbances and loss of body weight were serious side effects of $\mathbf{3 4}$ and $\mathbf{3 5}$.

Several prodrugs of Flourouracil were obtained by acylation or carbamoylation of N-1 and/or N-3 atoms of the pyrimidine ring of $\mathbf{1}$. In particular, an oral drug Carmofur (2) which is 1-hexylcarbamoyl derivative of $\mathbf{1}$ was launched in Japan in 1981 and later - in other countries [35]. The carbamate moiety in $\mathbf{2}$ decomposes gradually in neutral water or in basic conditions, but it is strongly resistant to acidic hydrolysis and hence can survive acid in the stomach. The 1-hexylcarbamoyl moiety also facilitates the rapid uptake of $\mathbf{2}$ through the cell membrane [36]. The metabolic activation of Carmofur involves oxidation and scission of the side-chain with slow release of 1 [37]. Two main routes of the side chain transformation are $\omega$-oxidation and ( $\omega-1)$-oxidation: metabolites $\mathbf{4 0 - 4 3}$ were detected after administration of Carmofur (Fig. 3) [38]. Non-enzymatic hydrolytic decomposition of 2 and its metabolites also contributes to release of $\mathbf{1}$.

Another oral prodrug of Fluorouracil, Atofluding (36) is a diacyl derivative of $\mathbf{1}$. Atofluding has reached Phase III clinical trials in China [39]. The activation of 36 includes its fast non-enzymatic hydrolysis to 3-o-toluyl-5-Fluorouracil (44) following oral administration; 44 is then slowly metabolized to 1 (Scheme 6) [40]. Since the acetyl group of Atofluding is not stable and prone to decompose, impairing quality control for the preparation, a possibility of direct application of $\mathbf{4 4}$ was also considered [41].<smiles>CC(=O)n1cc(F)c(=O)n(C(=O)c2ccccc2C)c1=O</smiles>

Scheme 6 Metabolic activation of Atofluding (36) 
An interesting idea was behind design of Emitefur (37), a prodrug of Fluorouracil which was developed by Otsuka Pharmaceutical and has reached Phase III clinical trials in Japan [3, 42, 43]. The structure of 37 contains the fragments of two biologically active components: Fluorouracil (1) and 3-cyano2,6-dihydroxypyridine (45), which is a potent inhibitor of dihydropyrimidine dehydrogenase. Therefore, $\mathbf{3 7}$ is a double prodrug which not only delivers Fluorouracil but also prevents its enzymatic biotransformation to the dihydropyrimidine derivative 12. Metabolic activation of $\mathbf{3 7}$ occurs via rapid cleavage of the ester bonds by esterase to give $\mathbf{4 5}$ and 1-ethoxymethyl-5-fluorouracil (46) (Scheme 7). The intermediate $\mathbf{4 6}$ is further metabolized to $\mathbf{1}$ by microsomal enzymes in the liver [44].

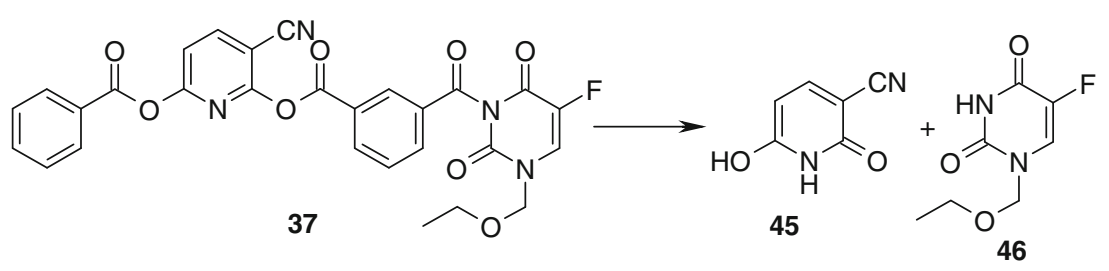

Scheme 7 Metabolic activation of Emitefur (37)

All the prodrugs of Fluorouracil discussed above contained the fragment of $\mathbf{1}$ in their structure; their transformation to $\mathbf{1}$ included hydrolysis reaction as the key step. On the contrary, 5-fluoro-2-pyrimidinone (5-FP, 38) which has been studied in Phase I clinical trials [45] is activated through oxidative process. In particular, pyrimidine $\mathbf{3 8}$ is transformed to $\mathbf{1}$ by aldehyde oxidase, which is present in high concentrations in the human livers but not in the gastrointestinal tract [46].

Two prodrugs of 1, Capecitabine (6) and Galocitabine (39), are 5-fluorocytidine derivatives. Both the compounds were developed by Hoffman La Roche; whereas Capecitabine was launched in 1998, Galocitabine was terminated at Phase II clinical trials [47]. Both the compounds are close analogues as well as prodrugs of Doxifluridine (5), which was used as the lead compound in their design. The main goals of such design were to minimize the mielotoxicity and to increase the tumor selectivity of $\mathbf{5}$. In fact, Capecitabine (6) indeed demonstrated minimal mielotoxicity in clinical studies. Although the therapeutic indices of $\mathbf{3 9}$ were much higher in mice tumor models than in the case of $\mathbf{5}$, it was not efficiently metabolised to the active species in humans. The metabolic activation of $\mathbf{6}$ and $\mathbf{3 9}$ includes their hydrolysis by carboxylesterase or acylamidase in liver to give 5 -deoxy-5-fluorocytidine (47), which is then transformed to 5 by cytidine deaminase (Scheme 8) [48]. 


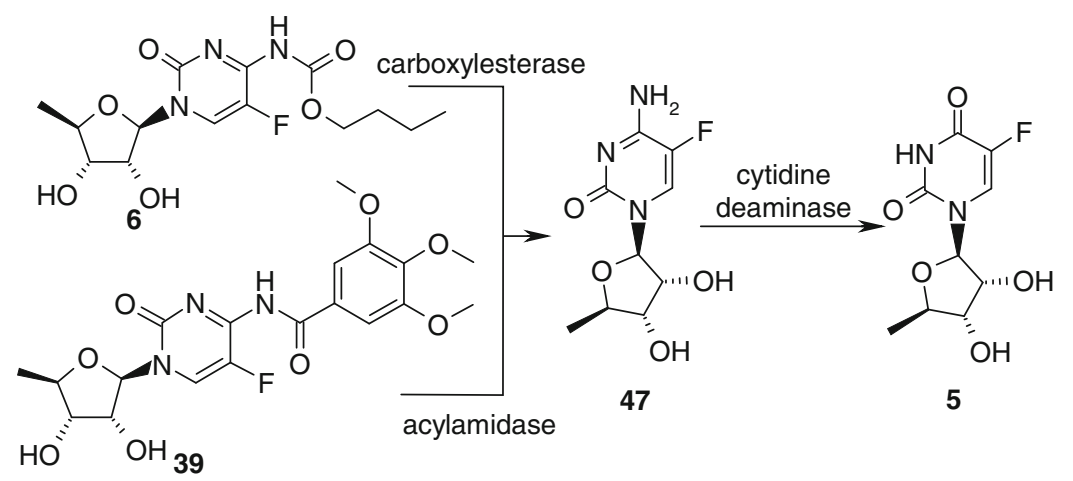

Scheme 8 Metabolic activation of Capecitabine (6) and Galocitabine (39)

Syntheses of Fluorouracil prodrugs relied on either chemical modification of 1 or direct fluorination of the corresponding pyrimidine derivatives. In particular, Tegafur (3) was obtained from 1 by reaction with 2,3-dihydrofuran [49-54], 2-chloro- [55, 56], 2-alkoxy- [57], 2-acetoxytetrahydrofuran [58, 59, 300], and 4-trimethylsilyloxybutyraldehyde dimethyl acetal (48) (Scheme 9) [60]. Alternatively, 3 was prepared via fluorination of compound 49 [61] or ester $\mathbf{5 0}$ [62].

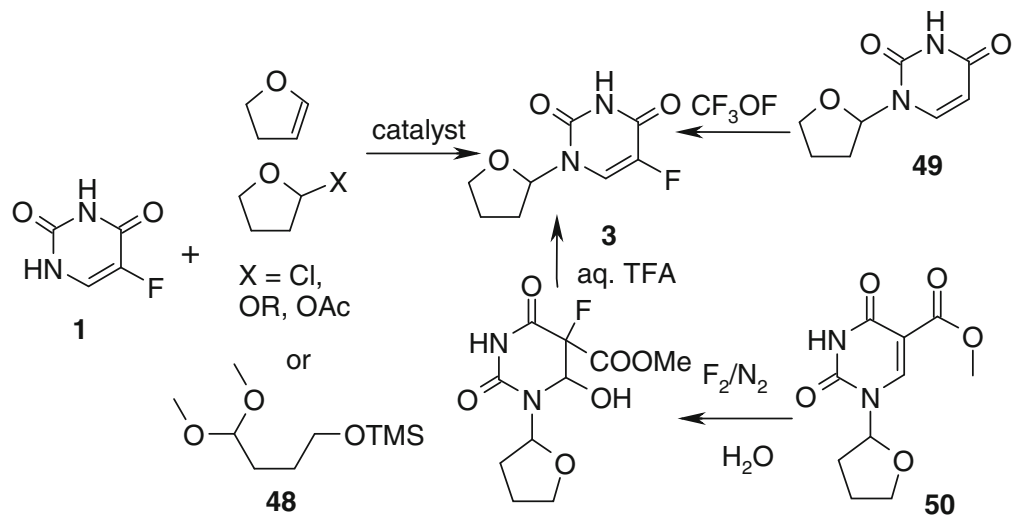

Scheme 9 Syntheses of Tegafur (3)

One of the early syntheses of Doxifluridine (5) [63, 64] commenced from Floxuridine (4) which reacted with thionyl chloride to give cyclic sulphite 51 (Scheme 10). Methanolysis of $\mathbf{5 1}$ upon treatment with sodium methylate gave 52, which was reduced with tributyltin to give $\mathbf{5}$. In an analogous approach, the compound $\mathbf{5}$ was prepared via iodide 53, in turn obtained from 4 in two steps (Scheme 11) [65]. It should be noted that direct transformation of $\mathbf{4}$ into the corresponding iodide was done with low yield of the product, hence the protection strategy was necessary to use. Bromide $\mathbf{5 4}$ was a key intermediate in one more analogous scheme [66]. 


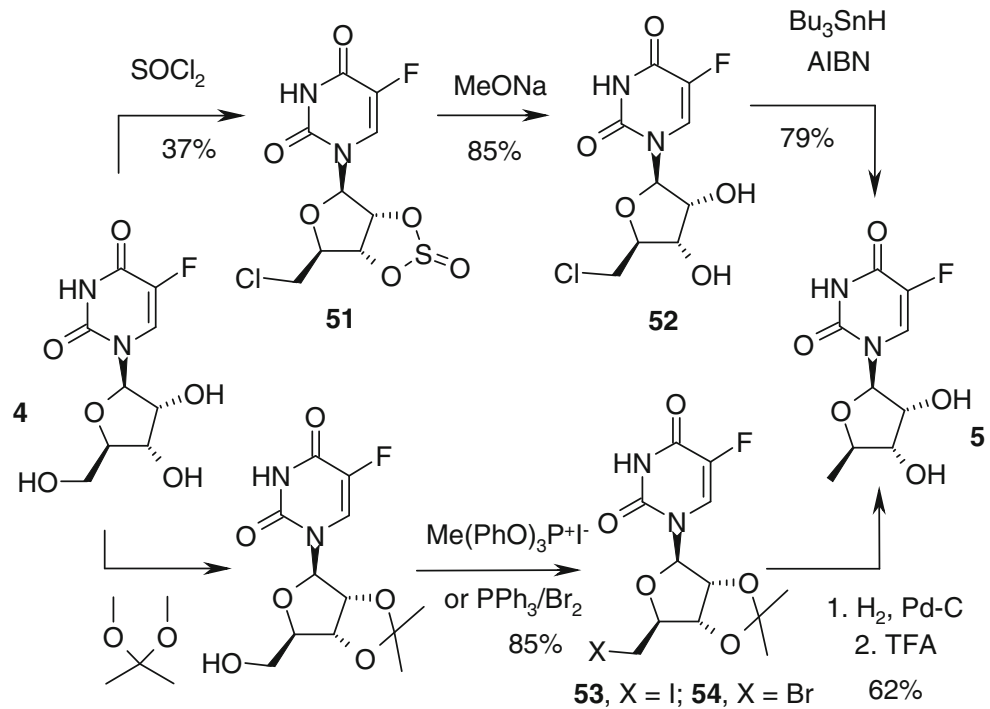

Scheme 10 Syntheses of Doxifluridine (5) from Floxuridine (4)

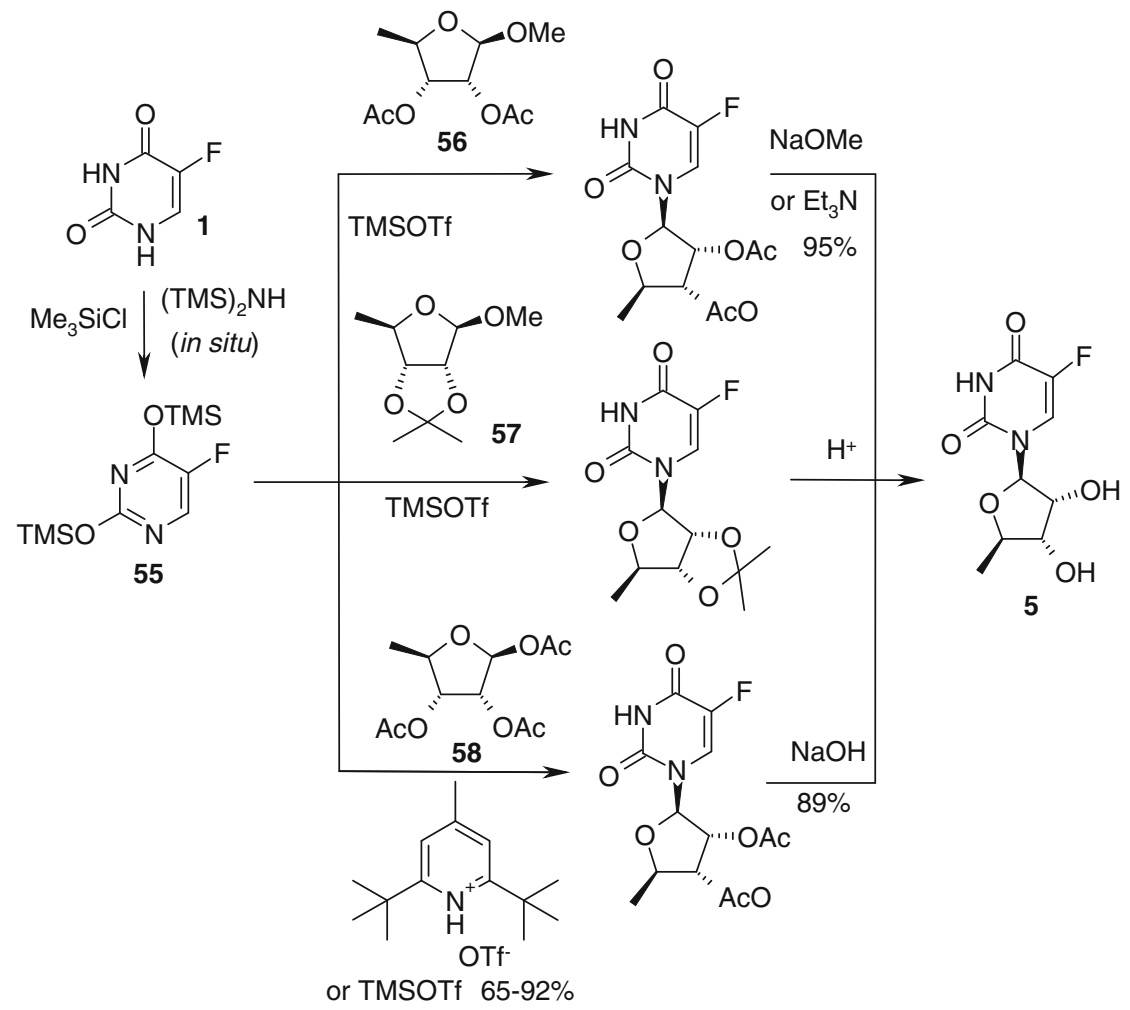

Scheme 11 Syntheses of Doxifluridine (5) from Fluorouracil (1) 
Several syntheses of Doxifluridine relied on glycosylation of Fluorouracil derivative 55. In particular, 5'-deoxyrybose derivatives $\mathbf{5 6}, \mathbf{5 7}$, and $\mathbf{5 8}$ were used for that purpose (Scheme 11) [67, 68]. Finally, direct fluorination of 5'-deoxyuridine derivatives with $\mathrm{F}_{2} / \mathrm{N}_{2}$ [69] or AcOF [70] was also described.

Syntheses of OGT 719 (33) relied on glycosylation of the compound $\mathbf{5 5}$ (Scheme 12). Reaction of $\mathbf{5 5}$ with bromide $\mathbf{5 9}$ [71, 72] or acetate $\mathbf{6 0}$ [73] gave tetraacetyl derivative 61, which was transformed to 33 upon deprotection. With $\mathbf{6 0}$ as the glycosylating reagent, in situ generation of $\mathbf{5 5}$ from Fluorouracil was also described [74].<smiles>COc1ncc(F)c(OC(C)(F)F)n1</smiles>

55<smiles>[X]C1OC(COC(C)=O)C(OC(C)=O)C(OC(C)=O)C1OC(C)=O</smiles>

59, $\mathrm{X}=\mathrm{Br}$ $60, X=O A C$<smiles>CC(=O)OCC1O[C@@H](n2cc(F)c(=O)[nH]c2=O)C(OC(C)=O)C(C(=O)O)C1C(=O)O</smiles>

61

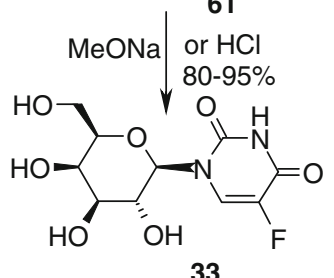

Scheme 12 Synthesis of OGT $719(\mathbf{3 3})$

TT-62 (34) was prepared as a free acid (62) from 63 which reacted with tosylchloride and tetradecylphosphate to give the corresponding phosphodiester, which upon deprotection gave 34 (Scheme 13) [75].<smiles>CC(=O)O[C@H]1C[C@H](n2cc(F)c(=O)[nH]c2=O)OC1CO</smiles><smiles>O=c1[nH]c(=O)n([C@H]2C[C@H](O)[C@@H](COP(=O)(O)O)O2)cc1F</smiles>

Scheme 13 Synthesis of TT-62 (34) as a free acid 62

Synthesis of T-506 (35) commenced from Fluorouracil derivative 64 (Scheme 14) [76]. Compound 64 reacted with 2-bromoethyl phosphorodichloridate to give bromide 65. Compound 65 was transformed to 35 upon reaction with trimethylamine. 
<smiles>[R]C(=O)O[C@H]1C[C@@H](n2cc(F)c(=O)[nH]c2=O)O[C@@H]1CO</smiles>

64, $\mathrm{R}=(Z)$-pentadec-7-en-1-yl<smiles>[R]C(=O)O[C@H]1C[C@H](n2cc(F)c(=O)[nH]c2=O)O[C@@H]1COP(=O)(O)OCCBr</smiles><smiles>[R]C(=O)OC1CC(n2cc(F)c(=O)[nH]c2=O)OC1COP(=O)([O-])OCC[N+](C)(C)C(C)(C)C</smiles>

Scheme 14 Synthesis of T-506 (35)

Synthesis of Carmofur (2) and Atofluding (36) was performed in obvious and straightforward manner. Carmofur (2) was prepared by reaction of Fluorouracil (1) and $n$-hexylisocyanate (Scheme 15) [77, 78]. Alternative approach included reaction of $\mathbf{1}$ with phosgene and then - with $n$-hexylamine.

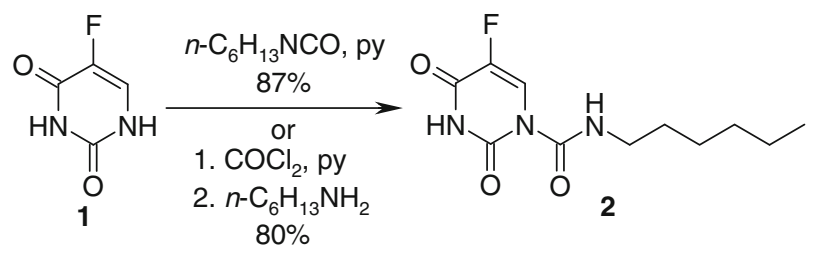

Scheme 15 Synthesis of Carmofur (2)

Synthesis of Atofluding (36) relied on a stepwise double acylation of Fluorouracil with acetic anhydride and then - with $o$-toluoyl chloride (Scheme 16) [79].

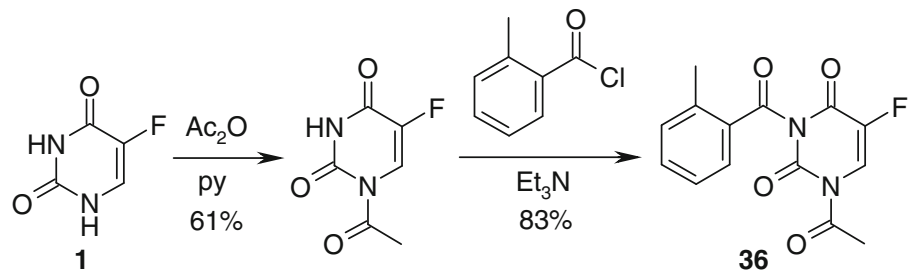

Scheme 16 Synthesis of Atofluding (36) 
Emitefur (37) was obtained by stepwise reaction of building blocks 46,67 , and $\mathbf{6 6}$ in the presence of triethylamine (Scheme 17) [80-82]. Compound $\mathbf{6 6}$ was prepared by benzoylation of 3-cyano-2,6-dihydroxypyridine (45), whereas $\mathbf{4 6}$ - by ethoxymethylation of the silyl derivative 55 .

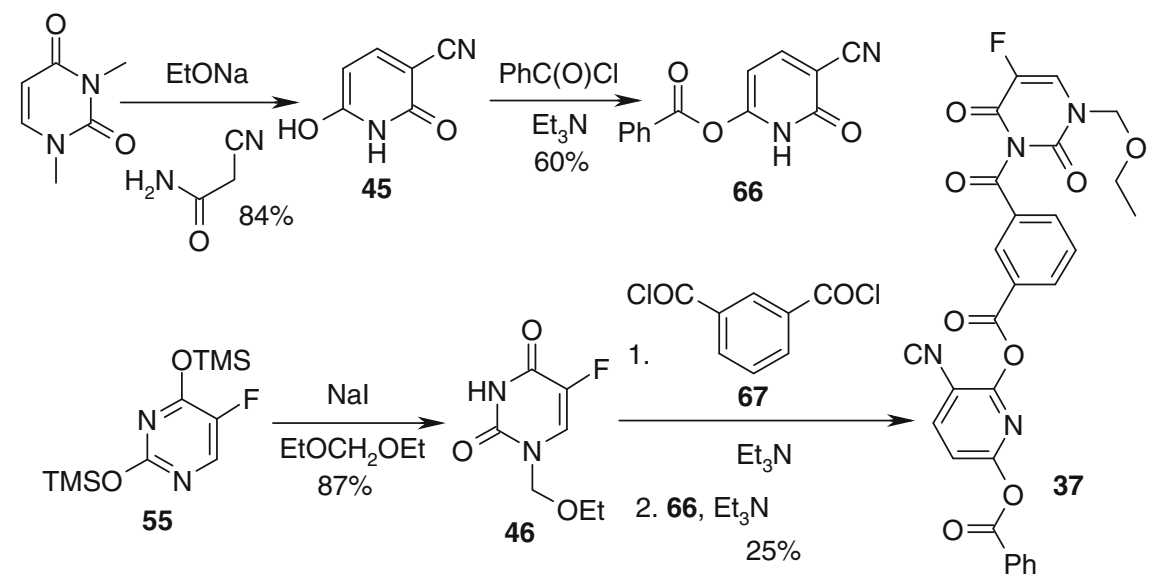

Scheme 17 Synthesis of Emitefur (37)

Early syntheses of 5-fluoro-2-pyrimidinone (38) relied on desulfurization of Fluorouracil thio-derivatives. In particular, reaction of pyrimidine derivatives 68 with $\mathrm{P}_{2} \mathrm{~S}_{5}$ followed by treatment with Raney nickel and gave alkoxy derivative 69, which was transformed to $\mathbf{3 8}$ upon acidic hydrolysis (Scheme 18) [83]. A more straightforward transformation sequence was also described; including reaction of Fluorouracil (1) with $\mathrm{P}_{2} \mathrm{~S}_{5}$ and reduction of thione $\mathbf{7 0}$ with Raney nickel $[84,85]$. Alternatively, the thione $\mathbf{7 0}$ was alkylated to give derivative 71, which was either oxidated and then hydrolyzed [86] or subjected to reaction with hydrazine and then - silver oxide [301]; in both cases, 38 was obtained. A completely different synthetic scheme commenced from fluoroacetic acid which was subjected to Vilsmeiertype formylation to give 2-fluoro-3-dimethylamino-acrolein (72) [87]. Reaction of 72 with triethyloxonium tetrafluoroborate and dimethylamine gave the salt $\mathbf{7 3}$, which led to $\mathbf{3 8}$ upon reaction with urea. Finally, $\mathbf{3 8}$ was also obtained by direct fluorination of 2-pyrimidinone [88, 89].

Syntheses of Capecitabine (6) started from 5-fluorocytosine (9) (see further sections for the preparation of $\mathbf{9}$, which is used as antifungal drug). In particular, compound 70 reacted with $1,2,3$-tri- $O$-acetyl-5-deoxy- $\beta$-D-ribofuranose $(\mathbf{5 8})$ to give diacetyl derivative $\mathbf{7 2}$, which was acylated with $n$-pentylchloroformate and then 

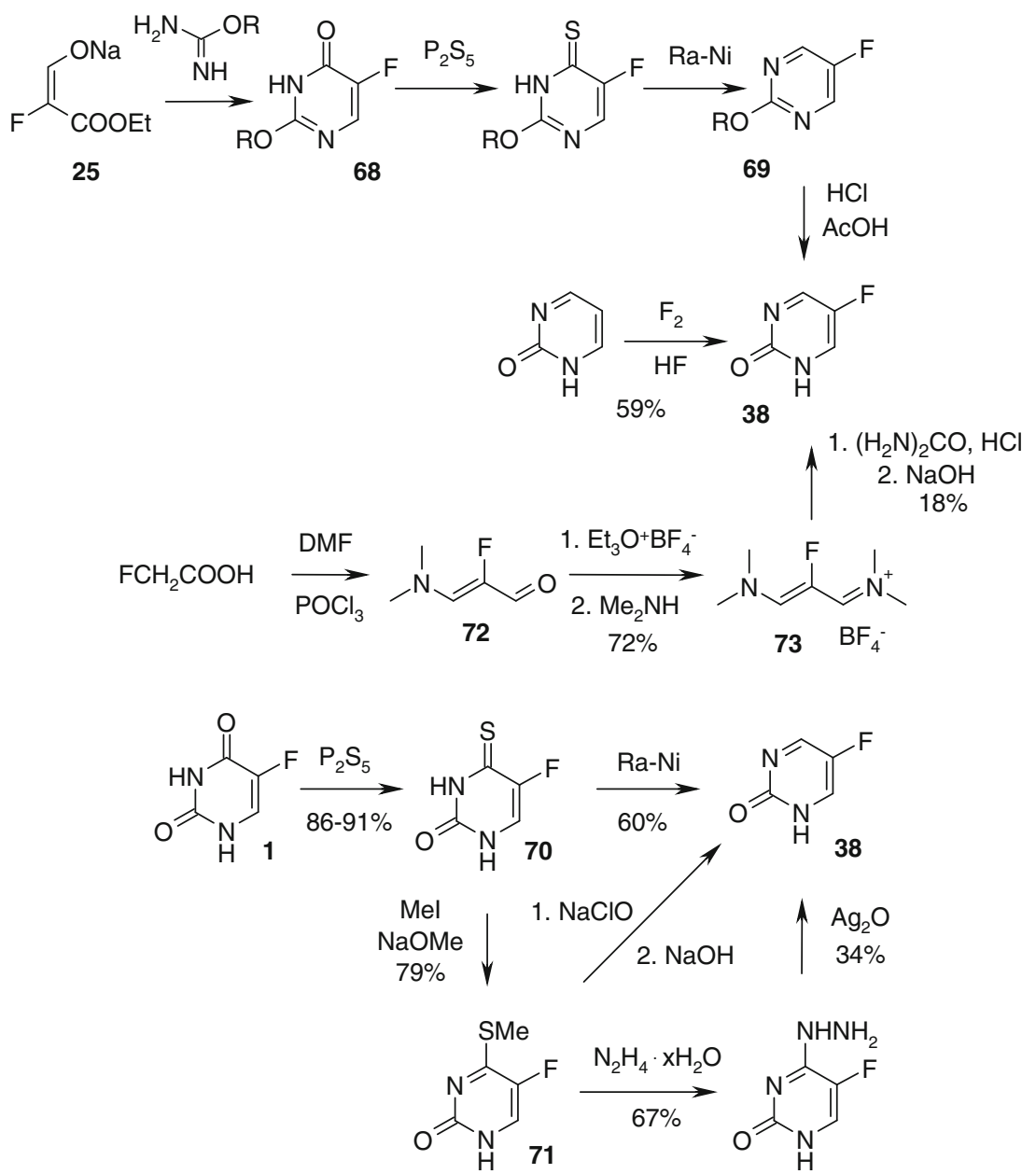

Scheme 18 Syntheses of 5-fluoro-2-pyrimidinone (38)

hydrolyzed, resulting in the formation of $\mathbf{6}$ (Scheme 19) [90-95]. Variations of this method using a silyl derivative of $\mathbf{7 0}$ instead of $\mathbf{7 0}$ itself $[68,96]$, as well as 1-O-acetyl-2,3-O-isopropylidene-5-deoxy-D-ribofuranose (73) (Scheme 20) [96] or 1,2,3-tri- $O$-methoxycarbonyl-5-deoxy-D-ribofuranose [97] as the sugar sources were also reported. Syntheses of Galocitabine (39) were performed analogously to that of Capecitabine, 3,4,5-trimethoxybenzoyl chloride being used instead of $n$ pentylchloroformate at the corresponding steps [68, 89, 90, 98]. 


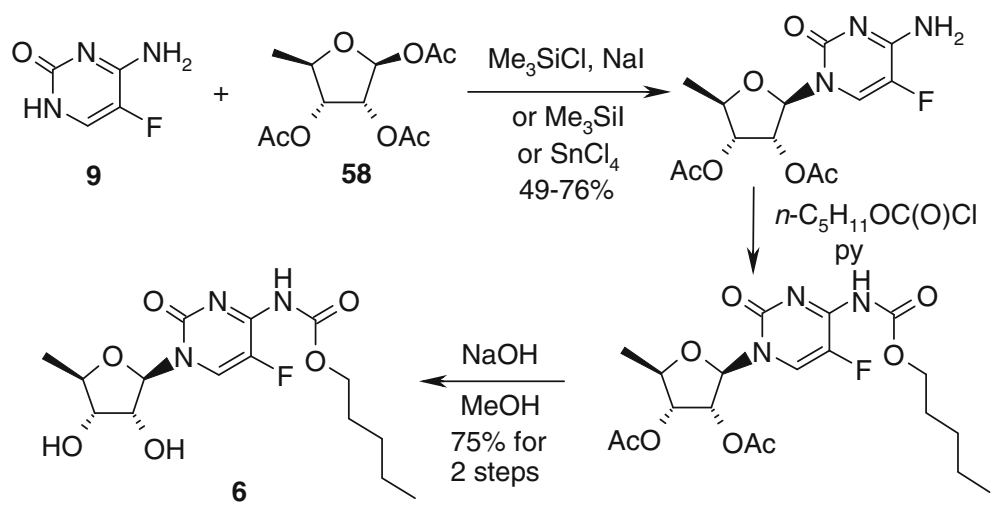

Scheme 19 Synthesis of Capecitabine (6) using 58 as the starting material

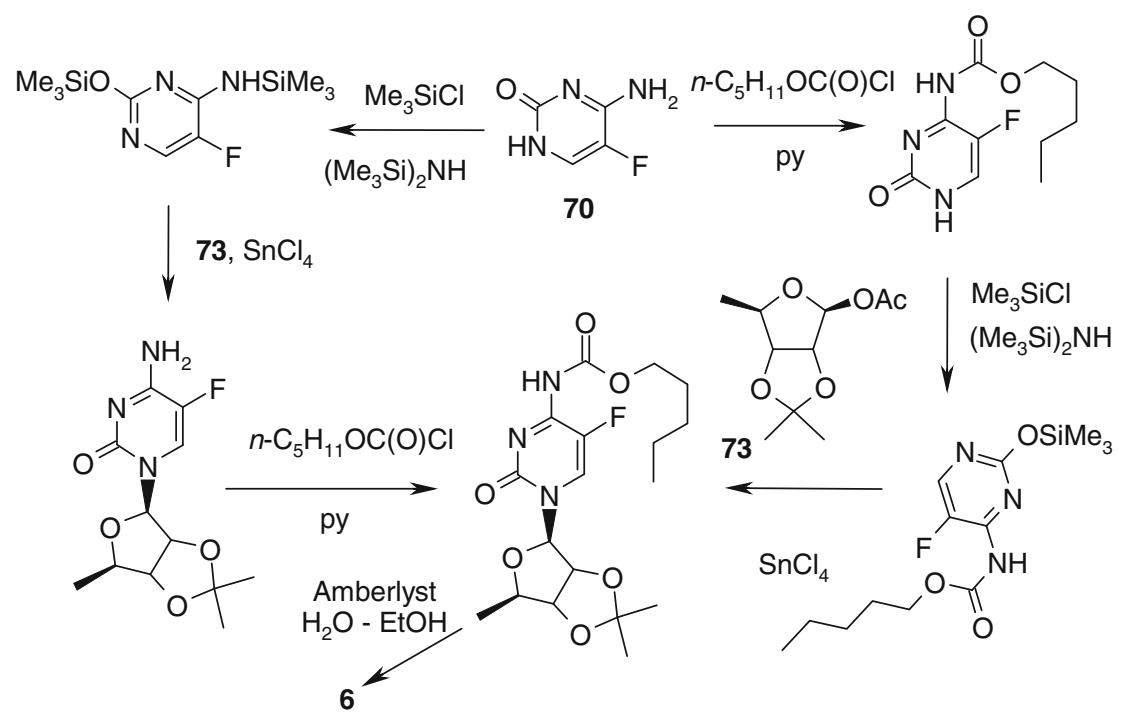

Scheme 20 Synthesis of Capecitabine (6) using 73 as the starting material

\subsection{Other Antimetabolites}

Apart from Floxuridine, Fluorouracil and its pro-drugs, there are two additional examples of anti-cancer agents which also act as antimetabolites and have reached clinical development phase, i.e. both Trifluridine (7) (as a component of TAS-102) and FTC-092 (74) (Fig. 4) were developed by Taiho Pharmaceutical. These 

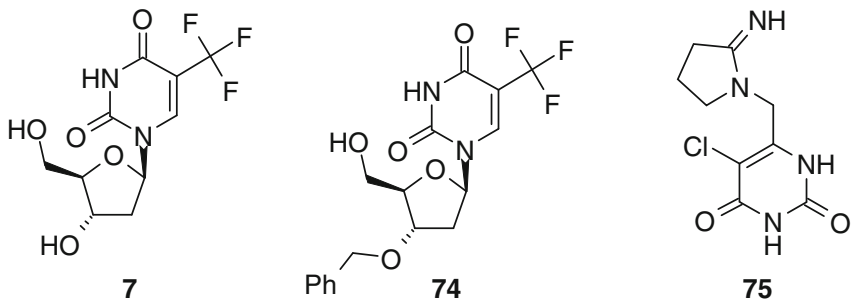

Fig. 4 Drug substances of TAS-102 (7, 75) and FTC-092 (74)

compounds are derivatives of $\alpha, \alpha, \alpha$-trifluorothymine and are thus structurally related to Fluorouracil. Trifluridine was approved by FDA as an ophthalmic drug against herpes virus in 1995 (see also further sections) [5]; it is now being investigated in Phase III clinical trials as a component of anti-cancer drug TAS-102 (which is a combination of 7 and Tipiracil (75)) [99] FTC-092 was evaluated for antitumor activity in Phase I clinical trials [3].

The active principle of both TAS-102 and FTC-092 with anti-cancer effect is Trifluridine (7). As in the case of Fluorouracil, one of the mechanisms by which compound 7 exhibits its antitumor activity is inhibition of thymidylate synthase [100]. More precisely, Trifluridine is transformed into $\alpha, \alpha, \alpha$-trifluorothymidine monophosphate (76) by thymidine kinase (Scheme 21); similarly to the Fluorouracil derivatives discussed in the previous sections, compound $\mathbf{7 6}$ is true inhibitor of thymidylate synthase. However, compound 7 exhibits an anticancer effect on colorectal cancer cells that have acquired Fluorouracil resistance as a result of the overexpression of thymidylate synthase.

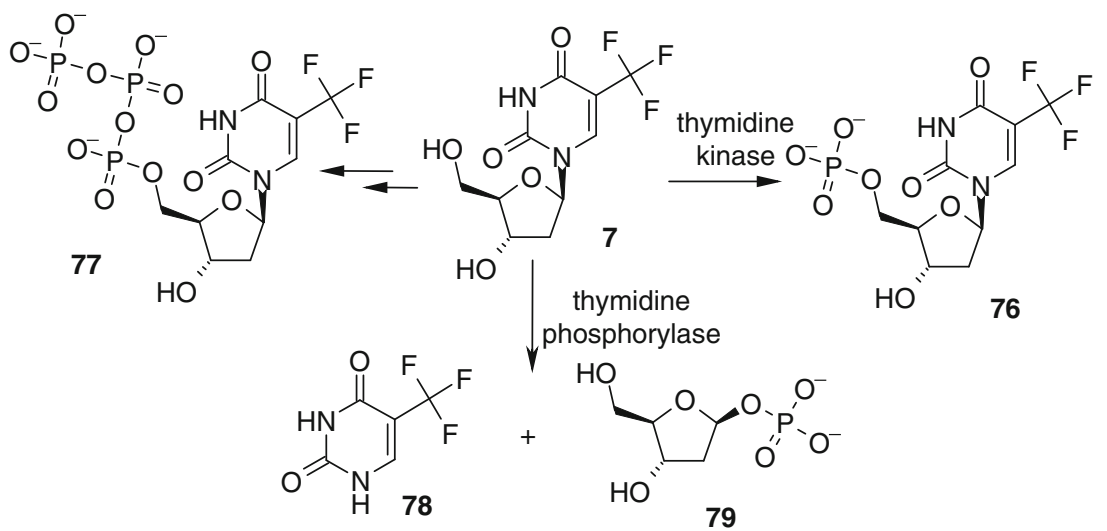

Scheme 21 Metabolic transformations of Trifluridine (7) 
Therefore, an alternative mechanism of action is also in operation, namely, incorporation of $\alpha, \alpha, \alpha$-trifluorothymidine triphosphate (77) into DNA, which results in single-strand breaks, followed by double-strand breaks when the cells progress to a subsequent DNA replication phase [101] The major drawback of Trifluridine (7) is its high susceptibility to biodegradation, which is catalysed by thymidine phosphorylase and gives $\alpha, \alpha, \alpha$-trifluorothymine (78) and 2-deoxy- $\alpha$-Dribose 1-phosphate (79) [102]. In the case of TAS-102, this issue is overcome by co-administration of thymidine phosphorylase inhibitor Tipiracil (75) [103], whereas improved biological effect of FTC-092 upon oral administration is achieved by its gradual biotransformation, mainly through the action of liver microsomes, releasing 7 over a long period [104].

The first synthesis of Trifluridine commenced from trifluoromethylacrylonitrile (80) which reacted with $\mathrm{HBr}$ and then with urea to give amide $\mathbf{8 1}$ in moderate yield. Hydrolysis of $\mathbf{8 1}$ was accompanied by cyclization and led to dihydropyrimidine $\mathbf{8 2}$ (Scheme 22). Two-step aromatization of $\mathbf{8 1}$ gave $\alpha, \alpha, \alpha$-trifluorothymine (78). Compound $\mathbf{7 8}$ was transformed to $\mathbf{7}$ in low yield ( $8 \%$ ) by enzymatic glycosylation [105]. The yield of the last step in this sequence was significantly improved when $\mathbf{7 8}$ was preliminarily transformed to bis-silyl derivative $\mathbf{8 3}$, and chloride $\mathbf{8 4}$ was used for glycosylation [106, 107].

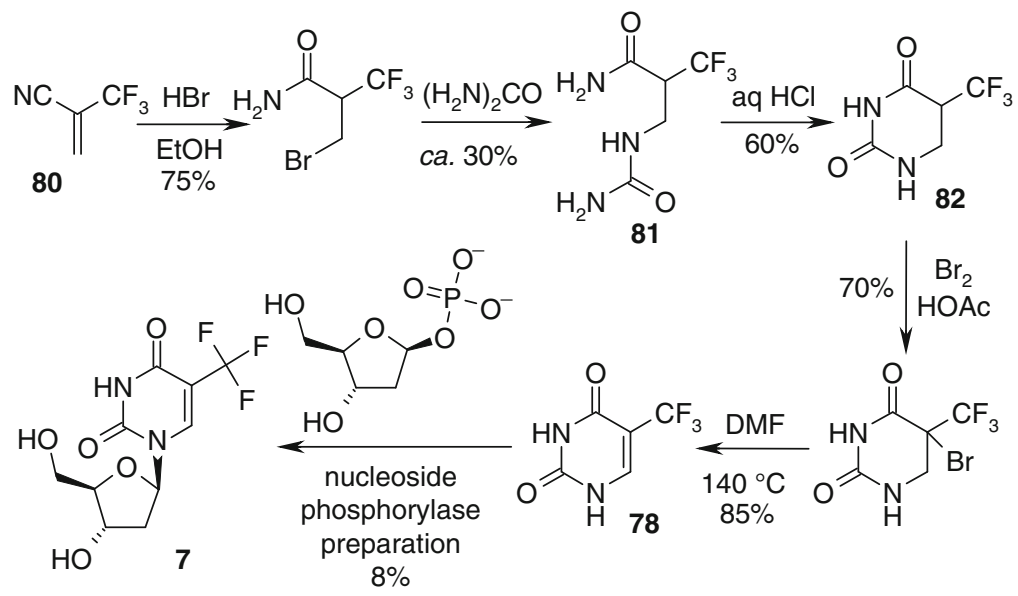

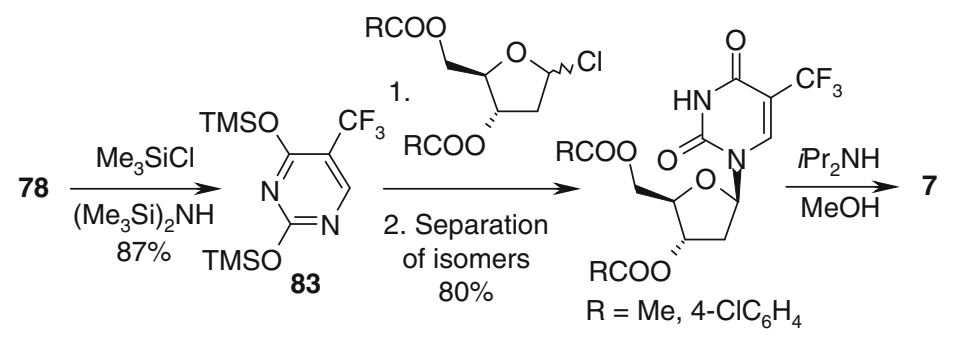

Scheme 22 Syntheses of Trifluridine (7) via $\alpha, \alpha, \alpha$-trifluorothymine (78) 
An alternative approach to 7 was based on direct trifluoromethylation of the corresponding deoxyuridine derivatives 32 or 84, using $\mathrm{CF}_{3} \mathrm{COOH}-\mathrm{XeF}_{2}$ [108] and $\mathrm{CF}_{3} \mathrm{I}-\mathrm{Cu}-\mathrm{HMPA}$ [109] as the reagents, respectively (Scheme 23).

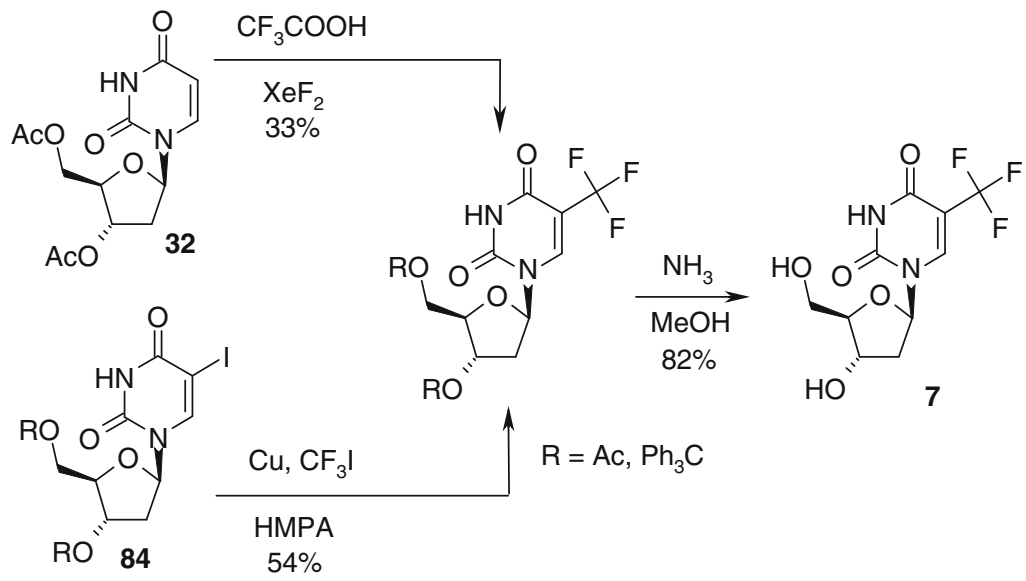

Scheme 23 Syntheses of Trifluridine (7) via trifluoromethylation of deoxyuridines

FTC-092 (74) was prepared by regioselective benzylation of Trifluridine (7) (Scheme 24) [110]. As in the case of 7, direct trifluoromethylation was also used for synthesis of 74. The following sequence was established as the most practical: tritylation of $2^{\prime}$-deoxy-5-iodouridine (85), 3'-O-benzylation, $N^{3}$-benzoylation, crosscoupling reaction with $\mathrm{CF}_{3} \mathrm{Cu}$ reagent, and acidic deprotection (Scheme 25) [111]. Alternatively, 74 was prepared in low yield by glycosylation of $\alpha, \alpha, \alpha$-trifluorothymine using the bis-silyl derivative $\mathbf{8 3}$ (Scheme 26) [112].

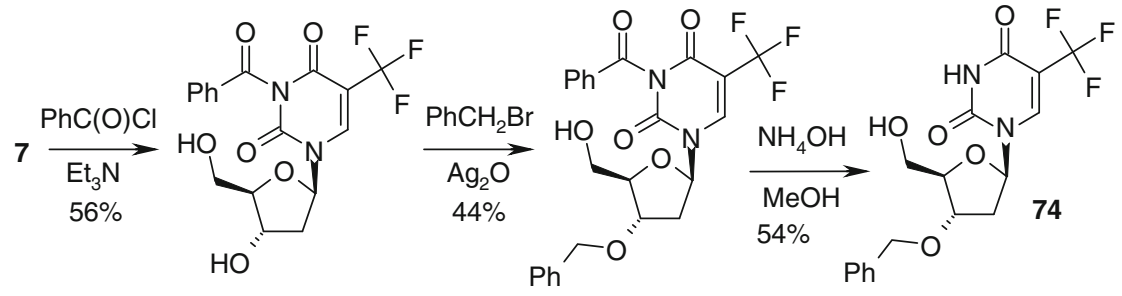

Scheme 24 Synthesis of FTC-092 (74) from Trifluridine (7) 
<smiles>O=c1[nH]c(=O)n([C@@H]2C[C@H](O)[C@@H](CO)O2)cc1I</smiles>

85<smiles>[2H]C([OH2+])(OC[C@H]1O[C@H](n2cc(I)c(=O)[nH]c2=O)C[C@@H]1O)c1ccccc1</smiles>

$\mathrm{HO}$

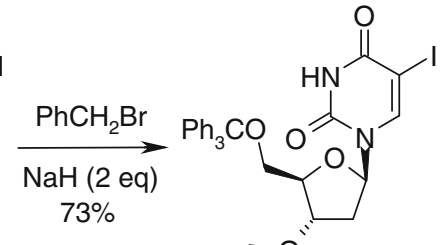

$73 \%$<smiles>O=C1C(C(F)(F)F)=CN2[C@@H](COCc3ccccc3)[C@H](OCc3ccccc3)C[C@H]2N1C(=O)c1ccccc1</smiles>

$\mathrm{Ph}$<smiles>CCOCc1ccccc1</smiles>

Scheme 25 Synthesis of FTC-092 (74) using direct trifluoromethylation<smiles>COc1ncc(C(F)(F)F)c(O[Si](C)(O)c2ccccc2)n1</smiles>

Scheme 26 Synthesis of FTC-092 (74) from $\alpha, \alpha, \alpha$-trifluorothymine derivative 83

\subsection{Kinase Inhibitors}

An approach to cancer treatment which relies on using fluorinated uracil analogues as antimetabolites is the most recognised in the field of fluorinated diazines relevant to medicinal chemistry. However, other strategies are also gaining momentum; in particular, several compounds which act as kinase inhibitors (i.e. 87-92) have reached clinical development phase (Table 2).

Compound LY-2835219 (87) is currently being developed by Eli Lilly and Co.; monomesylate salt of $\mathbf{8 7}$ has entered Phase I clinical trials in patients with advanced cancer in 2011 [113]. It acts as a potent oral inhibitor of the cyclin-dependent kinases 4 and 6 (CDK4/6), playing a key role in regulating cellular proliferation [114]. In particular, these cyclin D-dependent kinases facilitate progression of gap 1 cell cycle phase $\left(\mathrm{G}_{1}\right)$ by phosphorylating retinoblastoma susceptibility protein $(\mathrm{Rb})$, which prevents association of $\mathrm{Rb}$ with $\mathrm{E} 2 \mathrm{~F}$ transcription factor, and thus relieves transcriptional repression by the Rb-E2F complex. In addition, these 
Table 2 Fluorinated diazines as kinase inhibitors in clinical development phase [113]

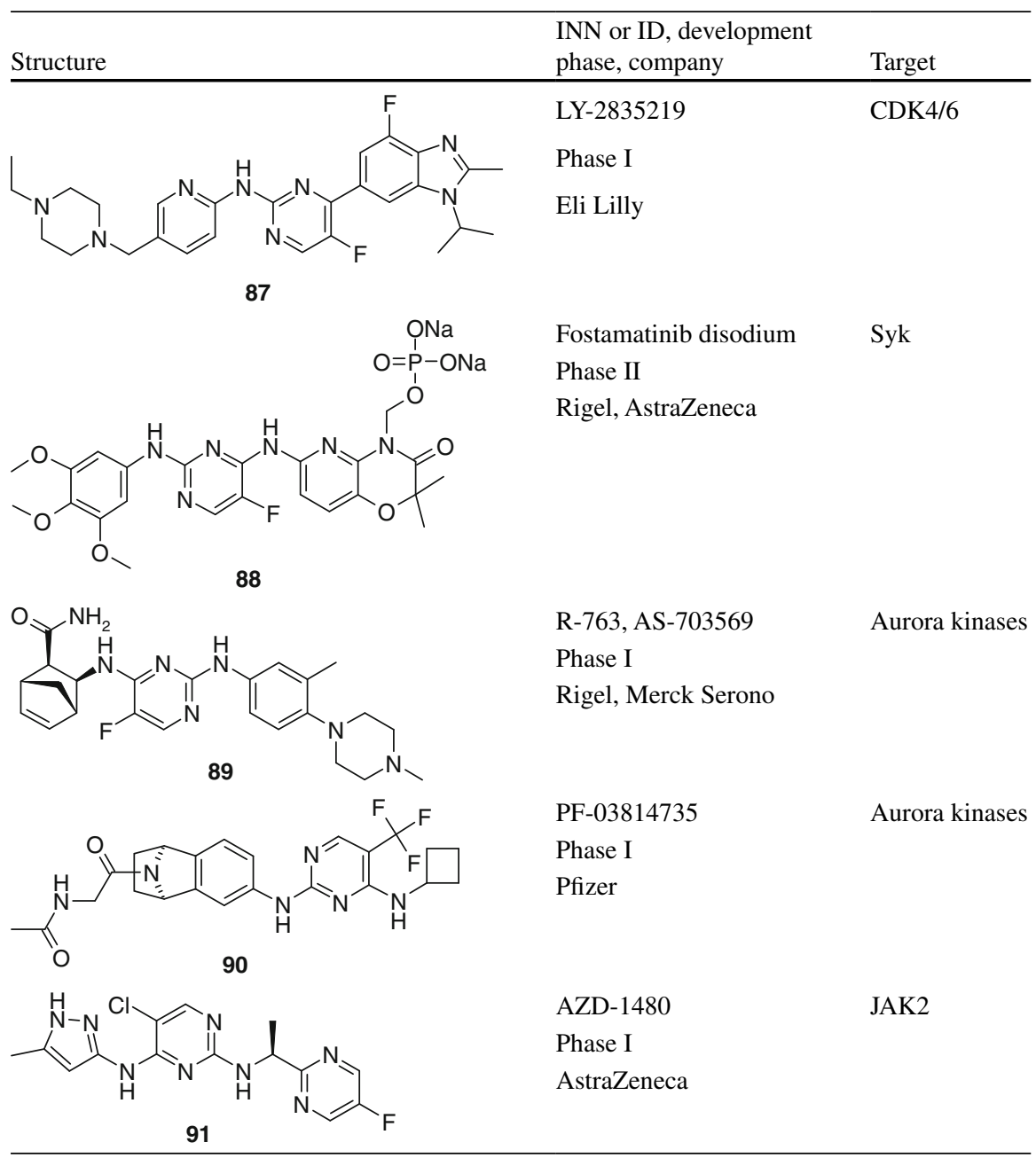

kinases also sequester CDK interacting and kinase inhibitory proteins (Cip/Kip) from their complexes with cyclin-dependent kinase 2 (CDK2), facilitating activation of CDK2 with cyclin E [115] Monomesylate salt of 87 inhibits CDK4 and CDK6 with IC50 values of 2 and $10 \mathrm{nM}$, respectively; moreover, it is able to cross blood-brain barrier and therefore has the potential for the treatment of brain tumors and metastases [114].

Fostamatinib disodium (Tamatinib fosdium, 88), which is prodrug of Tamatinib (92) (Scheme 27), was discovered by Rigel; it is currently studied in Phase II clinical trials by Rigel and Astra Zeneca Plc. for treatment of B-cell lymphoma [113]. Apart from that, compound $\mathbf{8 8}$ is also investigated as agent for treatment of autoimmune thrombocytopenia and rheumatoid arthritis. Because of its poor pharmaceutical properties, Tamatinib (92) is orally administered as the methylene phosphate 
prodrug 88. Fostamatinib disodium (88) is quickly cleaved to $\mathbf{9 2}$ by alkaline phosphatases that are present on the apical brush-border membranes of the intestinal enterocytes, after which the more hydrophobic 92 can be readily absorbed [116].

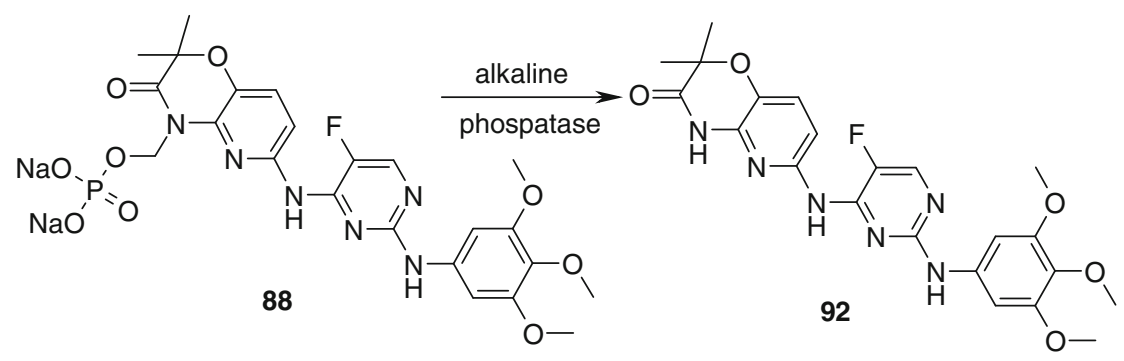

Scheme 27 Metabolic activation of Fostamatinib disodium (88)

Tamatinib (92) acts as an ATP-competitive inhibitor of Spleen tyrosine kinase (Syk) - a non-receptor tyrosine kinase which is a key component of the B-cell receptor (BCR) signaling pathway [117]. It is shown that BCR-mediated signaling through Syk occurs to a greater degree and for a longer duration in neoplastic cells than in nonmalignant B-cells. Inhibition of the Syk pathway prevents chronic lymphocytic leukemia (CLL) cells from interacting with the microenvironment, and promotes proapoptotic signals.

R-763 (89), also known as AS-703569, is another kinase inhibitor discovered by Rigel. It was investigated in Phase I clinical trials for several types of tumors by Rigel and Merck Serono; the latest study was terminated in 2012, concerning a review of the available clinical data and low probability of completing the trial based on the observed recruitment rate [113]. Compound 89 inhibits Aurora kinases -serine/threonine kinases which are essential for cell proliferation, mainly due to regulation of gap 2 and mitotic cell cycle phases $\left(\mathrm{G}_{2} / \mathrm{M}\right)$. Over-expression of Aurora kinases is found in several human cancers and correlated with histological malignancy and clinical outcomes. Although the biological functions of two types of Aurora kinases (A and B) are different, in both cases their inhibition induces apoptosis of the cell, leading to similar phenotypes. Some other kinases are also inhibited by 89, in particular Fms-like tyrosine kinase 3 (FLT3) [118].

One more Aurora kinase inhibitor - PF-03814735 (90) - was developed by Pfizer; it has been investigated in Phase I clinical trials for treatment of solid tumors (the study completed in 2012) [113]. PF-03814735 was generally well tolerated with manageable toxicities, and a recommended phase II dose could be established; however, clinical or metabolic antitumour activity was limited [119]. Similarly to R-763 (89), compound 90 inhibits both Aurora A and B kinases; other kinases are affected to a lesser extent [120]. Therefore, PF-03814735 (90) produces a block in cytokinesis, resulting in inhibition of cell proliferation and the formation of polyploid multinucleated cells.

AZD-1480 (91) was developed by AstraZeneca and studied in Phase I clinical trials for treatment of advanced solid malignancies (the study terminated in 2012) [113]. AZD-1480 is an ATP-competitive inhibitor of Janus kinase 2 (JAK2) - an 
intracellular non-receptor tyrosine kinase that transduce cytokine-mediated signals via the Janus kinase - signal transducer and activator of transcription (JAK-STAT) signaling pathway. In particular, inhibition of JAK2 blocks Stat3 signaling, associated with chronic cytokine stimulation in some tumors [121]. X-Ray diffraction study of complex formed by $\mathbf{9 1}$ and JAK2 shows that the donor-acceptor-donor hydrogen-bonding motif provided by aminopyrazole fragment forms three hydrogen bonds with an adenine binding pocket, whereas the fluoropyrimidine ring occupies a nearby hydrophobic pocket [122].

Synthesis of LY-2835219 (87) relied on selective functionalization of 2,4-dichloro-5-fluoropyrimidine (93), which can be easily obtained from Fluorouracil (1) (Scheme 28) [123]. First, boronic ester 94 was prepared from aniline 95 in three steps, including benzimidazole ring construction and palladiumcatalyzed coupling with pinacol diborane. Suzuki-type reaction of 93 and 94 resulted in selective functionalization at $\mathrm{C}-4$ of the pyrimidine ring and gave chloride 96. Buchwald-Hartwig coupling of 96 with amine 97 (prepared in two steps from 1-ethylpiperazine (98) and (99)) gave the final product $\mathbf{8 7}$.

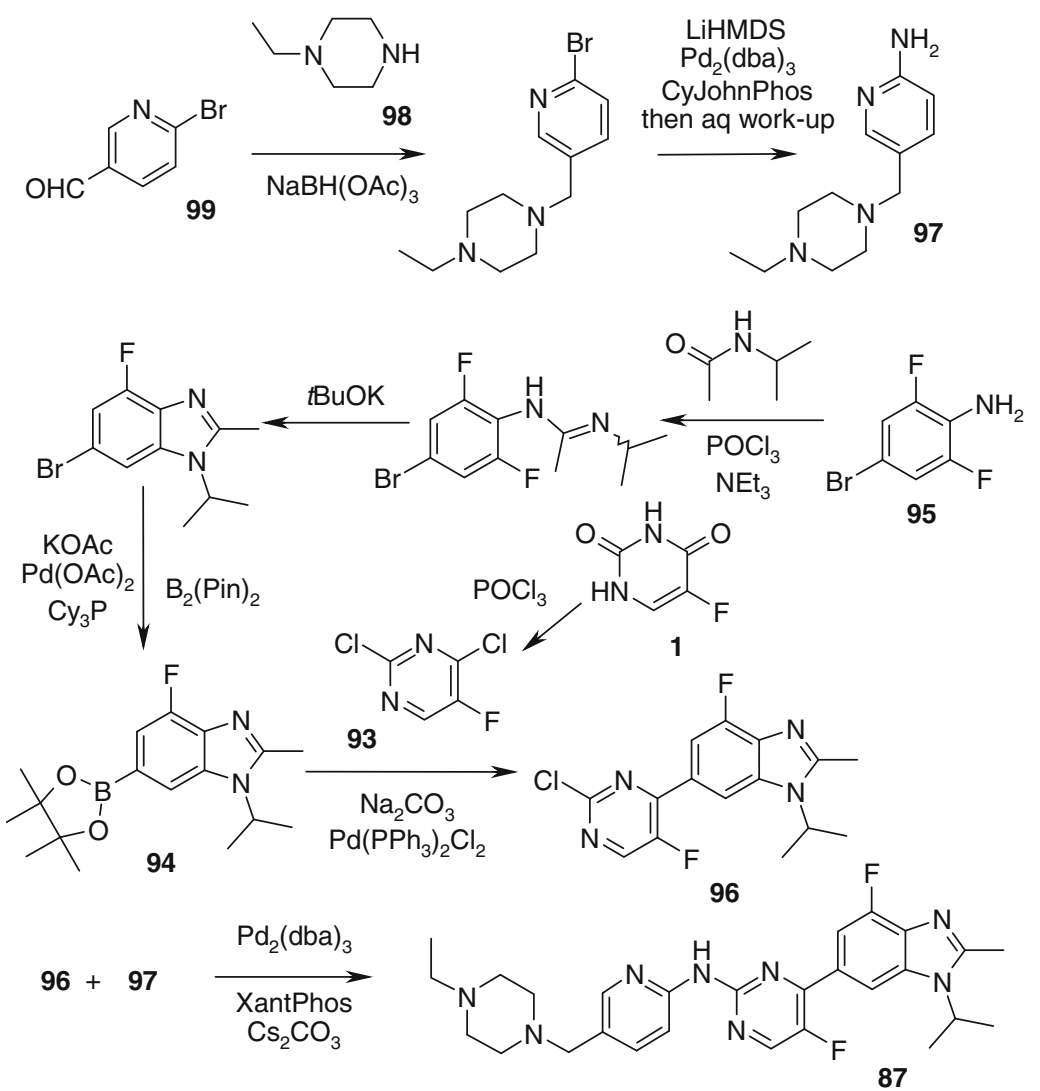

Scheme 28 Synthesis of LY-2835219 (87) 
Analogously, selective functionalization of $\mathbf{9 3}$ was used for the preparation of Fostamatinib disodium (88) (Scheme 29). In particular, reaction of 93 with equimolar amount of amine $\mathbf{1 0 0}$ and then - with 3,4,5-trimethoxyaniline (101) gave Tamatinib (92) [124]. It should be noted that no detailed procedures of performing these transformations were given in the initial patent; moreover, synthesis of the starting compound (amine 100) is not documented to date. To obtain Fostamatinib disodium (88), compound 92 was treated with chloride 102 and $\mathrm{Cs}_{2} \mathrm{CO}_{3}$; further deprotection subsequent and salt formation gave the target product $\mathbf{8 8}$ [125].

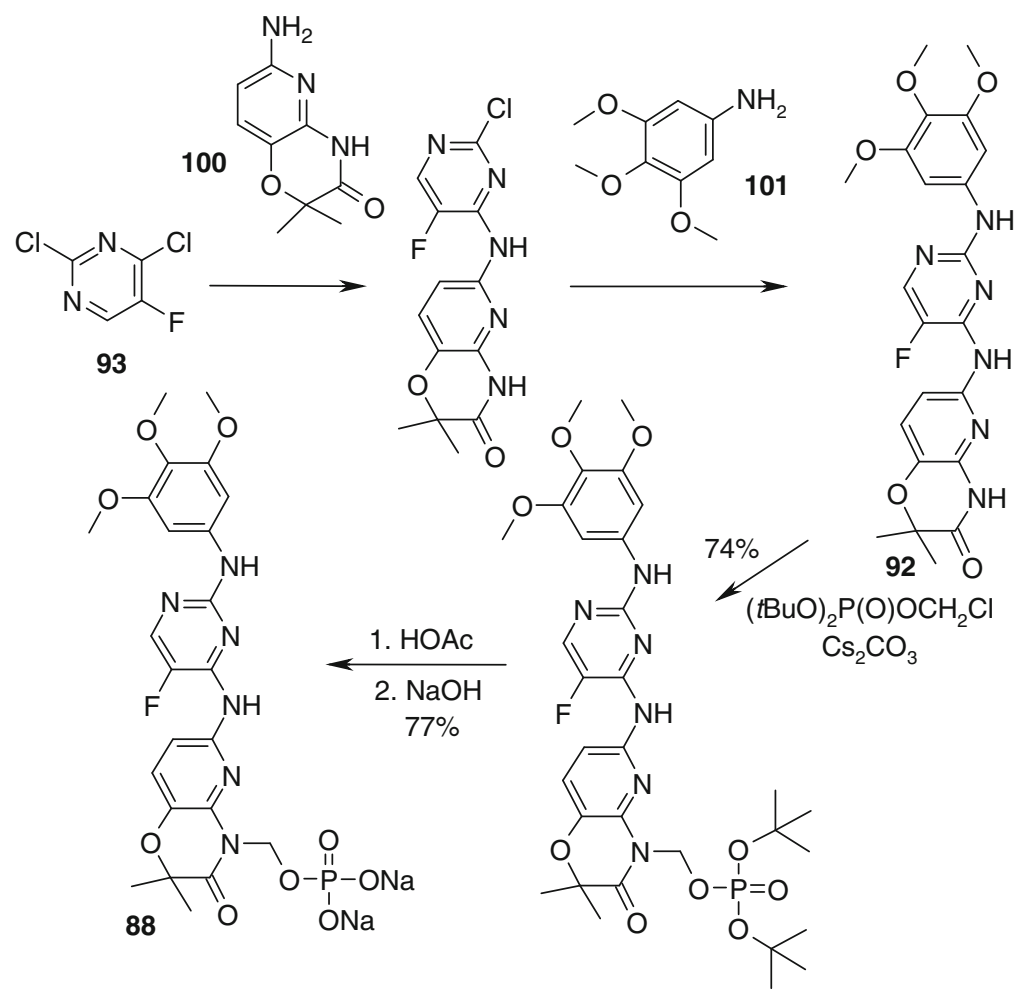

Scheme 29 Synthesis of Fostamatinib disodium (88)

Similar approach was used for the synthesis of R-763 (89) (Scheme 30) [126]. In this case, lactam 102, which was obtained from norbornadiene (103) and Graf isocyanate $\left(\mathrm{ClSO}_{2} \mathrm{NCO}\right)$, was protected with $\mathrm{Boc}_{2} \mathrm{O}$ and then subjected to ringopening with aqueous ammonia to give amide 104. Deprotection of 104 followed by arylation with 93 gave an intermediate 105, which was then treated with $\mathrm{N}$-arylpiperazine derivative $\mathbf{1 0 6}$ (prepared in two steps from 4-fluoro-3-methylnitrobenzene (107)) to give racemic 89. Optically pure 89 was obtained either by chiral stationary phase HPLC applied at different steps of the synthesis, or via enzymatic resolution of Boc-protected lactam $\mathbf{1 0 2}$. 


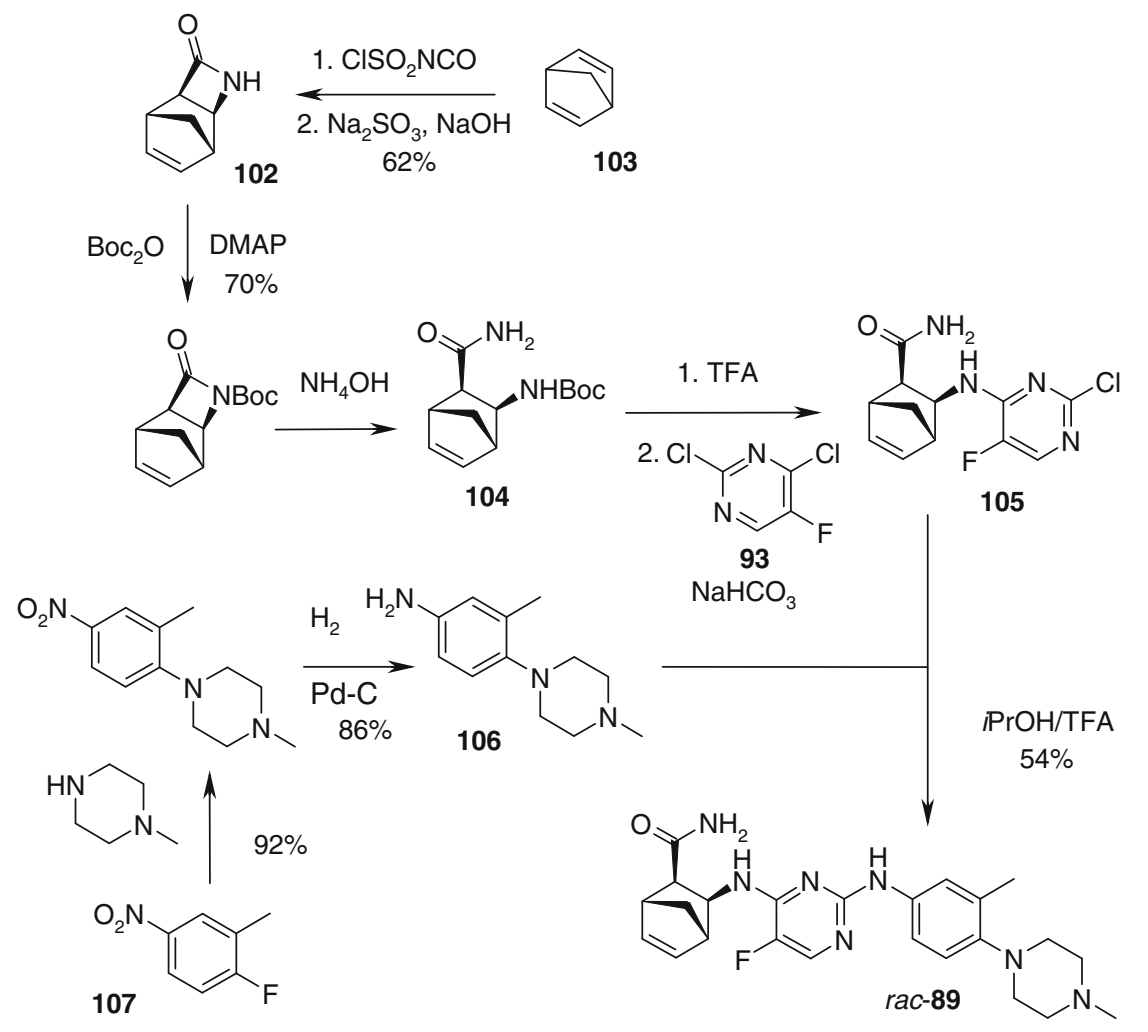

Scheme 30 Synthesis of racemic R-763 (rac-89) (Relative configurations are shown)

It is not surprising that synthesis of PF-03814735 (90) also followed analogous strategy, 2,4-dichloro-5-trifluoromethylpyrimidine (111) being used as a key fluorinated diazine building block instead of $\mathbf{9 3}$ (Scheme 31) [302]. The synthetic scheme commenced from amine $\mathbf{1 0 8}$ which was $N$-trifluoroacetylated, then nitrated, and subjected to a change of the protecting group to give Boc derivative 109. Two alternative pathways were developed for further transformations. In the first one, compound 109 was reduced into fused aniline derivative 110 which reacted with 111 to give compound 112. Deprotection of $\mathbf{1 1 2}$ followed by coupling with $N$-acetylglycine led to the formation of chloride $\mathbf{1 1 3 .}$

Alternatively, compound $\mathbf{1 0 9}$ was deprotected, coupled with $N$-acetylglycine, reduced catalytically and then arylated with 111 to give 113. Finally, compound 113 reacted with cyclobutyl amine to give the final product $\mathbf{9 0}$ as racemate. Both enantiomers of 90 were also obtained using this scheme if Boc derivative 109 was subjected to chiral stationary phase HPLC prior further transformations.

Although a similar strategy was used for the preparation AZD-1480 (91), in this case the fluorinated diazine moiety is not in a central part of the molecule; hence a different approach was used for the construction of the fluorinated 


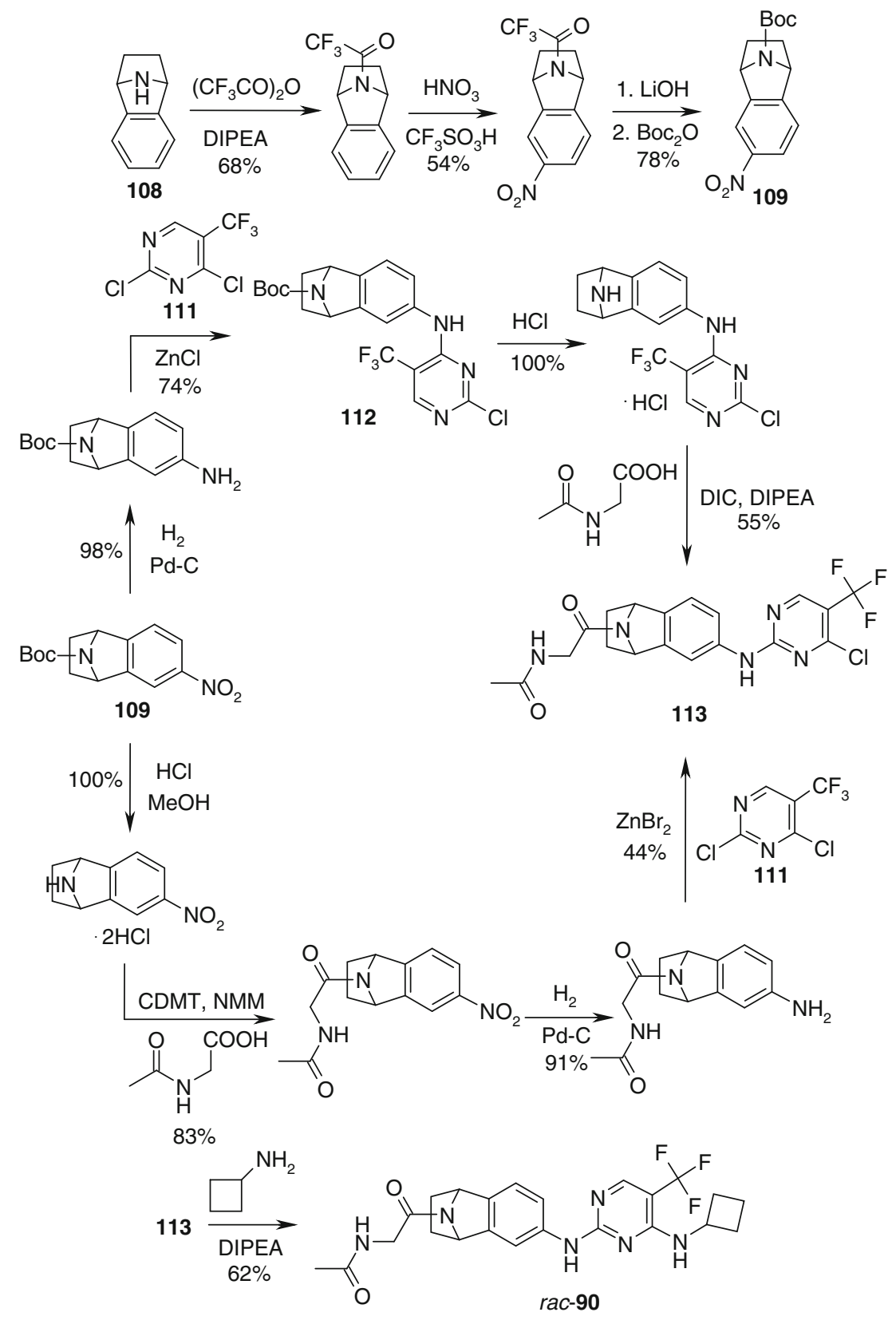

Scheme 31 Synthesis of racemic PF-03814735 (rac-90) 
pyrimidine fragment. As in the previous syntheses discussed in this section, 91 was obtained by selective functionalization of 5-substited 2,4-dichloropyrimidine derivative (i.e. 114), first by reaction with aminopyrazole 115 and then - with chiral amine 116 (Scheme 32) [122, 127]. For the preparation of enantiopure 116, two approaches were developed, both starting from nitrile 117, in turn prepared from 2-chloro-5-fluoropyrimidine (118) [127]. In the first method, compound 117 was reduced with DIBAL into aldehyde 119, which reacted with Ellman's sulfinamide $\mathbf{1 2 0}$ to give imine 121. Reaction of $\mathbf{1 2 1}$ with $\mathrm{MeMgBr}$ and subsequent deprotection led to the formation of 116. Alternatively, $\mathbf{1 1 7}$ was treated with $\mathrm{MeMgBr}$ and then $-\mathrm{Ac}_{2} \mathrm{O}$ to give enamine derivative 122, which was subjected to enantioselective rhodium-catalyzed hydrogenation with $(S, S)$-Et-DuPhos as a chiral ligand. The resulting chiral amide $\mathbf{1 2 3}$ was obtained with more than $99 \%$ ee. After a change of the protecting group, Boc derivative $\mathbf{1 2 4}$ was deprotected to give the target amine hydrochloride $\mathbf{1 1 6 .}$

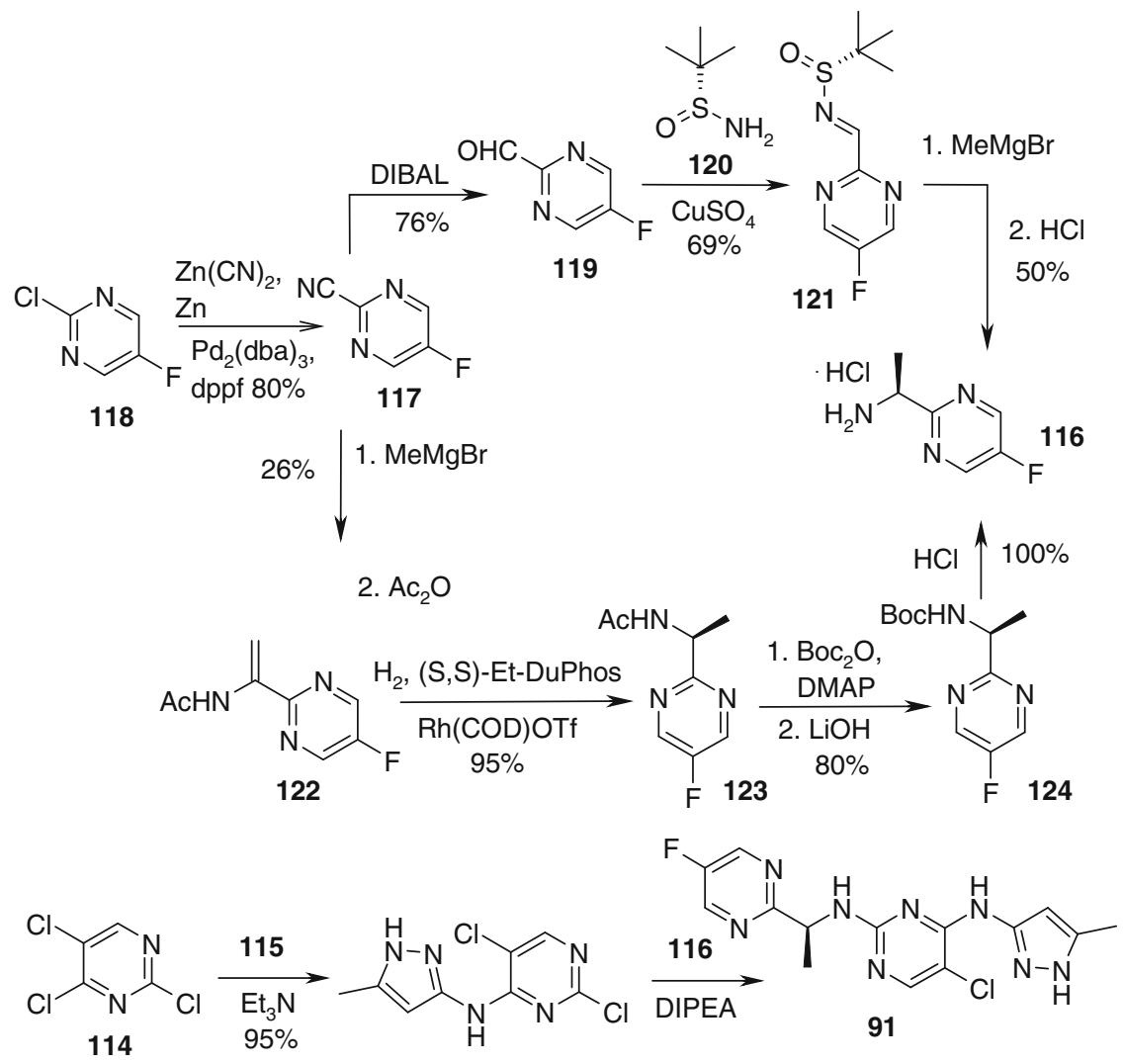

Scheme 32 Synthesis of AZD-1480 (91) 


\section{Antiviral, Antibacterial and Antifungal Agents}

\subsection{Anti-HIV Agents}

The fight against HIV infection is another important field where fluorinated diazines have remarkable record, including approved drug Emricitabine (8) and 7 compounds that have reached clinical development phase (compounds 125-131) (Table 3). All these compounds act as HIV reverse transcriptase inhibitors and fall into two categories: fluorocytidine analogues (8 and 125-127) and trifluoromethyl-substituted quinazolone derivatives (128-131).

Table 3 Anti-HIV drugs - derivatives of fluorinated diazines [5, 113]

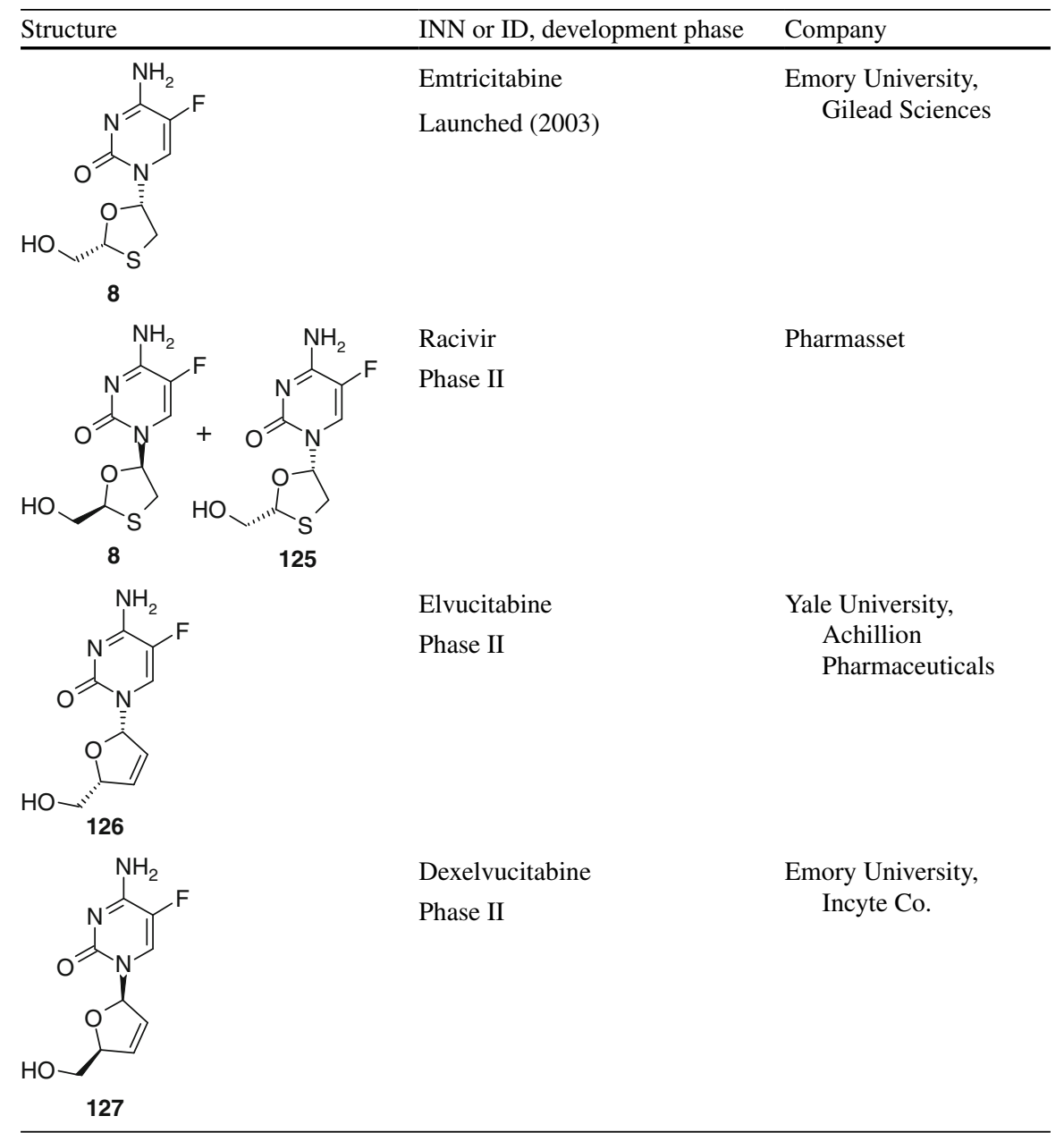


Table 3 (continued)

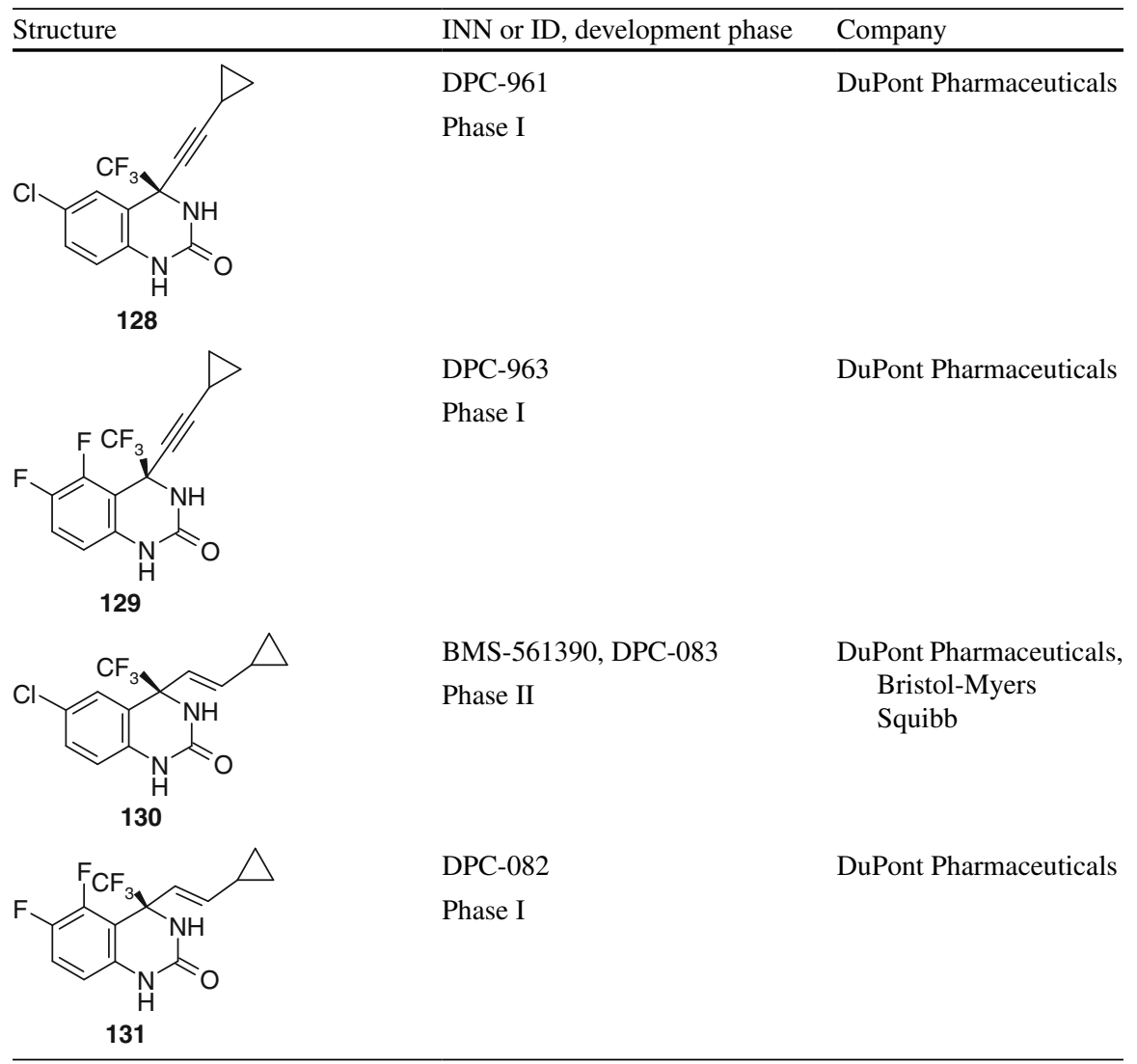

Emtricitabine (8) was discovered in Emory University (Atlanta, USA); development of the drug was completed by Gilead Sciences, and the compound was approved by FDA under trade name Emtriva ${ }^{\circledR}$ in 2003. It is also marketed in combinations with other anti-HIV agents, i.e. Tenofovir (132, used as a prodrug) $\left(\right.$ Truvada $\left.^{\circledR}\right)$, Efavirenz (133) and Tenofovir $\left(\right.$ Atripla $\left.^{\circledR}\right)$, Rilpivirine (134) and Tenofovir (Complera ${ }^{\circledR}$ ), and Elvitegravir (135), Cobicistat (136), and Tenofovir (Stribild ${ }^{\circledR}$ ) [5] Emricitabine is a close analogue of Lamivudine (137), which is an example of nucleoside analogs - an important class of reverse transcriptase inhibitors, which has gained much attention since the initial success of the first representative, Zidovudine (138) [128] (Fig. 5).

Emtricitabine (8) was discovered in Emory University (Atlanta, USA); development of the drug was completed by Gilead Sciences, and the compound was approved by FDA under trade name Emtriva ${ }^{\circledR}$ in 2003. It is also marketed in 


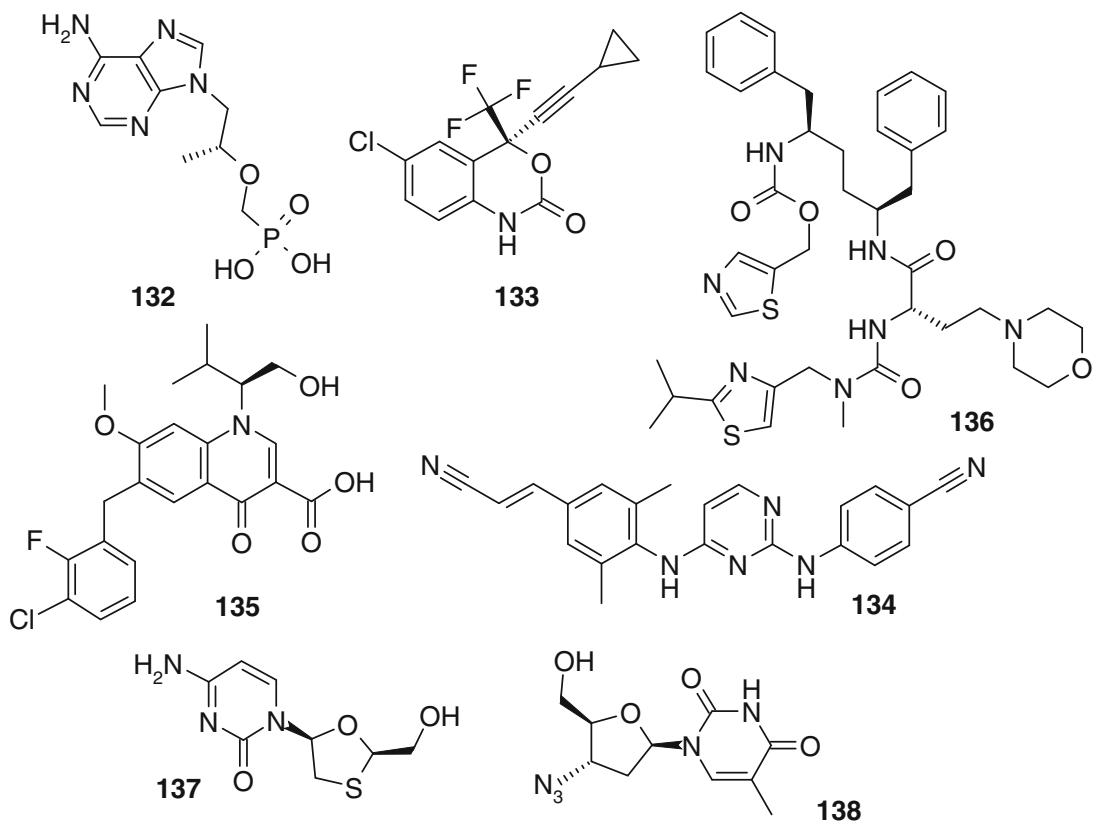

Fig. 5 Some active ingredients of anti-HIV drugs

combinations with other anti-HIV agents, i.e. Tenofovir (132, used as a prodrug) (Truvada ${ }^{\circledR}$ ), Efavirenz (133) and Tenofovir (Atripla ${ }^{\circledR}$ ), Rilpivirine (134) and Tenofovir $\left(\right.$ Complera $^{\circledR}$ ), and Elvitegravir (135), Cobicistat (136), and Tenofovir $\left(\right.$ Stribild $^{\circledR}$ ) [5] Emricitabine is a close analogue of Lamivudine (137), which is an example of nucleoside analogs - an important class of reverse transcriptase inhibitors, which has gained much attention since the initial success of the first representative, Zidovudine (138) [128].

Emtricitabine (8) is very similar to Lamivudine (137) with respect to its activity, convenience, safety and resistance profile; the only remarkable difference is longer intracellular half-life of $\mathbf{8}$. Analogously to 137, the biologically active form of $\mathbf{8}$ is triphosphate 139, which is formed by a stepwise phosphorylation of $\mathbf{8}$ (Scheme 33). Compound 139 can be considered as 2,3-dideoxycytidine trifosphate analogue and acts as a competitive inhibitor and alternate substrate of the normal deoxycytidine triphosphate (140). As a competitive inhibitor of the normal substrate, 139 inhibits incorporation of $\mathbf{1 4 0}$ into the growing DNA chain by viral reverse transcriptase; as an alternate substrate, it is incorporated into this chain (as 141) and acts as a chain terminator (since $\mathbf{1 4 1}$ is missing the $3^{\prime}$-hydroxyl group required for further chain elongation) $[128,129]$. 

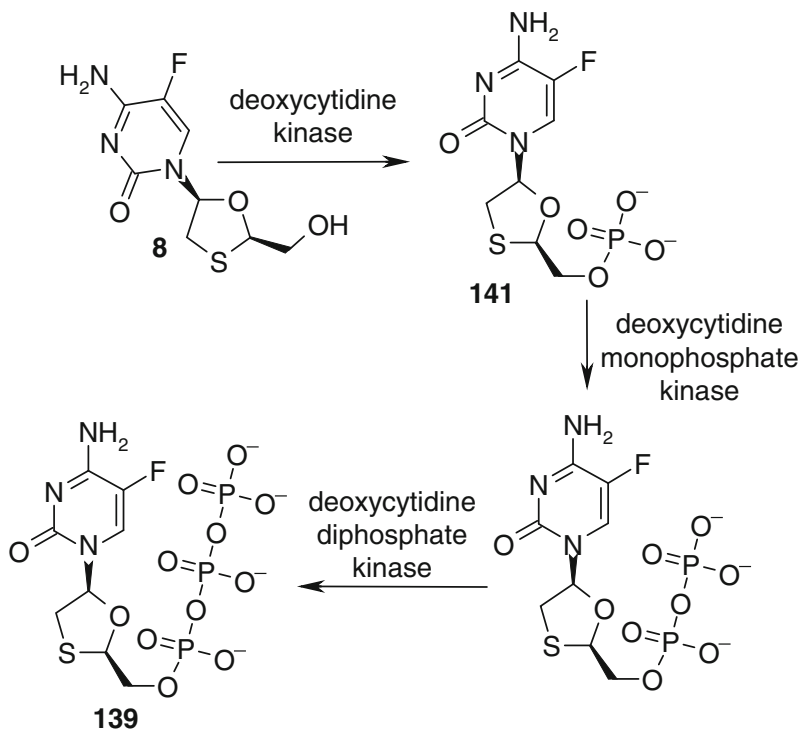<smiles>Nc1ccn([C@H]2C[C@H](O)[C@@H](COP(=O)([O-])OP(=O)([O-])OP(=O)([O-])[O-])O2)c(=O)n1</smiles>

140

Scheme 33 Metabolic activation of Emtricitabine (8)

Although Emtricitabine might have the potential for toxicity caused by interaction with human mitochondrial DNA enzymes, both in vitro and in vivo testing results show that this is not a serious issue. Low toxicity of $\mathbf{8}$ as compared to other nucleoside reverse transcriptase inhibitors is a remarkable advantage of this drug. As with all representatives of this class, the major drawback of $\mathbf{8}$ is rapid development of drug resistance by a single point mutation of viral reverse transcriptase [129]. The main route of elimination of $\mathbf{8}$ is renal excretion, mostly unchanged ( $86 \%$ of the dose). The metabolic transformations of Emtricitabine include oxidation of the sulphur atom to form the $3^{\prime}$-sulfoxide diastereomers $(9 \%)$ and conjugation with glucuronic acid to give $2^{\prime}$ - $O$-glucuronide (4\%) [130].

A racemic form of Emtricitabine, Racivir, was also studied in clinics by Pharmasset and has reached Phase II trials [113], designed to measure its efficacy in patients harbouring virus resistant to Lamivudine. It was shown that $D(+)$ enantiomer $\mathbf{1 2 5}$ is less potent and more toxic than Emtricitabine itself. One of the reasons behind lower potency of $\mathbf{1 2 5}$ is that $\mathbf{8}$ is phosphorylated by deoxycitidine kinase to a greater extent; therefore, the active form $(\mathbf{1 3 9})$ is formed more readily for (-)-enantiomer [131, 132].

Elvucitabine (126) and its enantiomer Dexelvucitabine (127) were discovered in Yale University (New Haven, USA) and Emory University (Atlanta, USA), respectively. Both compounds were further developed by commercial companies (Achillion Pharmaceuticals and Incyte Co., respectively), and have reached Phase II clinical trials [113]. Development of $\mathbf{1 2 7}$ was terminated due to inability to pair with other cytidine analogues and higher risk of hyperlipasemia. Phase II studies of $\mathbf{1 2 6}$ were suspended because of bone marrow suppression in several patients [133]. The 
mode of action of Elvucitabine is quite similar to that of Emtricitabine; the major advantages of $\mathbf{1 2 6}$ include long plasma half-life (up to ten times greater than that of 8) and superior potency against common resistance mutations [134].

Four compounds DPC-961 (128), DPC-961 (129), DPC-083 (130), and DPC-082 (131) were developed by DuPont Pharmaceuticals as non-nucleoside reverse transcriptase inhibitors. Al the compounds have reached Phase I clinical trials; DPC-083 (130) was further progressed into Phase II trials by Bristol-Myers Squibb after the company had acquired DuPont Pharmaceuticals; however, the development was stopped in 2003 due to poor pharmacokinetics [135]. The compounds are close analogues of Efavirenz (133) - a non-nucleoside reverse transcriptase inhibitor approved by FDA in 1998 [5]. All the compounds 128-131 showed similar to Efavirenz activity towards wild-type virus in vitro; however, they were more effective towards singlemutation variants and showed lower plasma serum protein binding [136, 137].

It might be assumed that mechanism of action of 128-131 is similar to that of Efavirenz, which is known to bind within the non-nucleoside inhibitor binding pocket of reverse transcriptase [138], both spatially and also functionally associated with the substrate-binding site.

Metabolism of DPC-961 (128) was studied in rats. Analogously to Efavirenz, the main metabolite is glucuronide conjugate 142 (more than $90 \%$ of excreted dose in the bile) (Scheme 34). However, a glutatione conjugate 143 was also isolated, which is presumably formed via oxirene intermediate 144; in this view, metabolism of 128 was different from that of 133 [139].

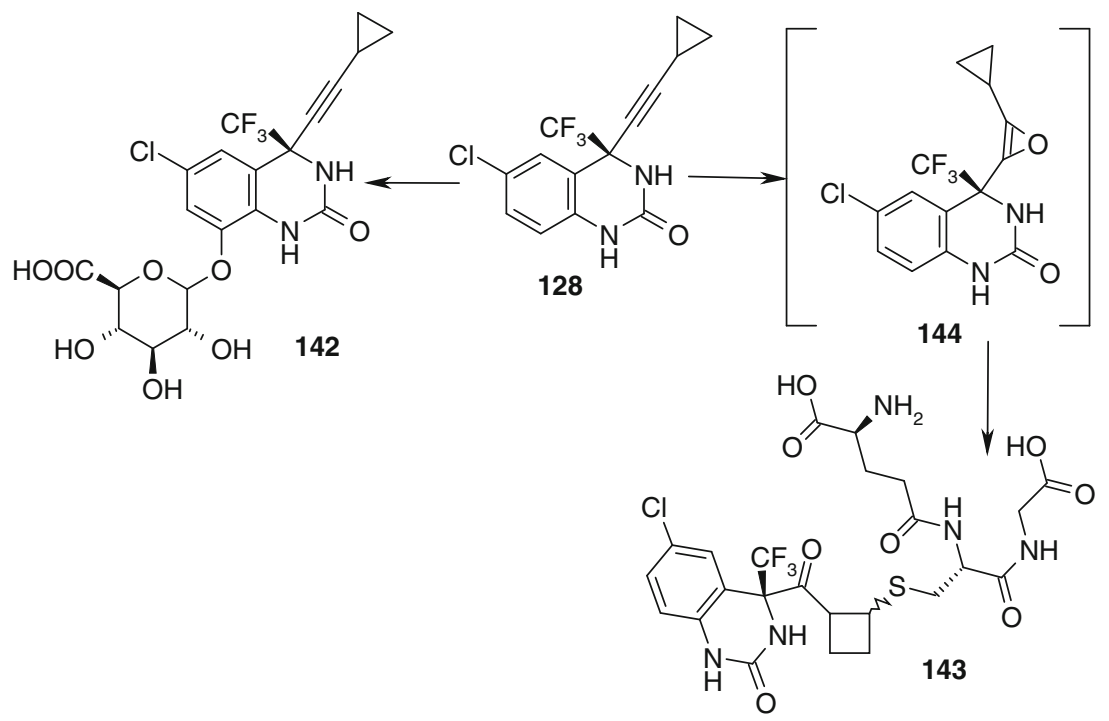

Scheme 34 Main metabolites of DPC-961 (128) in rats 
Early synthesis of Emtricitabine (8) commenced from L-gulose (145) (Scheme 35) [140]. Selective tosylation of $\mathbf{1 4 5}$ followed by acetylation gave 146. Treatment of 146 with $\mathrm{HBr}$ in $\mathrm{AcOH}$ yielded the bromo derivative 147, which was refluxed with $O$-ethylxanthate and then deacetylated using $\mathrm{NH}_{4} \mathrm{OH}$ in $\mathrm{MeOH}$ to obtain the 1,6-thioanhydro-L-gulopyranose (148). Selective oxidative cleavage of vicinal cis diol in 148 by $\mathrm{NaIO}_{4}$ and reduction with $\mathrm{NaBH}_{4}$, followed by protection of the resulting diol as the acetonide yielded the 1,3-oxathiolane derivative 149. Silyl protection of the hydroxyl group followed by deprotection of the isopropylidene moiety afforded derivative 150. Oxidative cleavage of vicinal diol 150 by $\mathrm{Pb}(\mathrm{OAc})_{4}$ followed by pyridinium dichromate (PDC) oxidation gave the acid $\mathbf{1 5 1}$. Treatment of $\mathbf{1 5 1}$ with $\mathrm{Pb}(\mathrm{OAc})_{4}$ - pyridine in anhydrous THF afforded acetate $\mathbf{1 5 2}$. Reaction of $\mathbf{1 5 2}$ with fluorocytosine derivative 153, separation of anomers and subsequent deprotection gave $\mathbf{8}$. The same

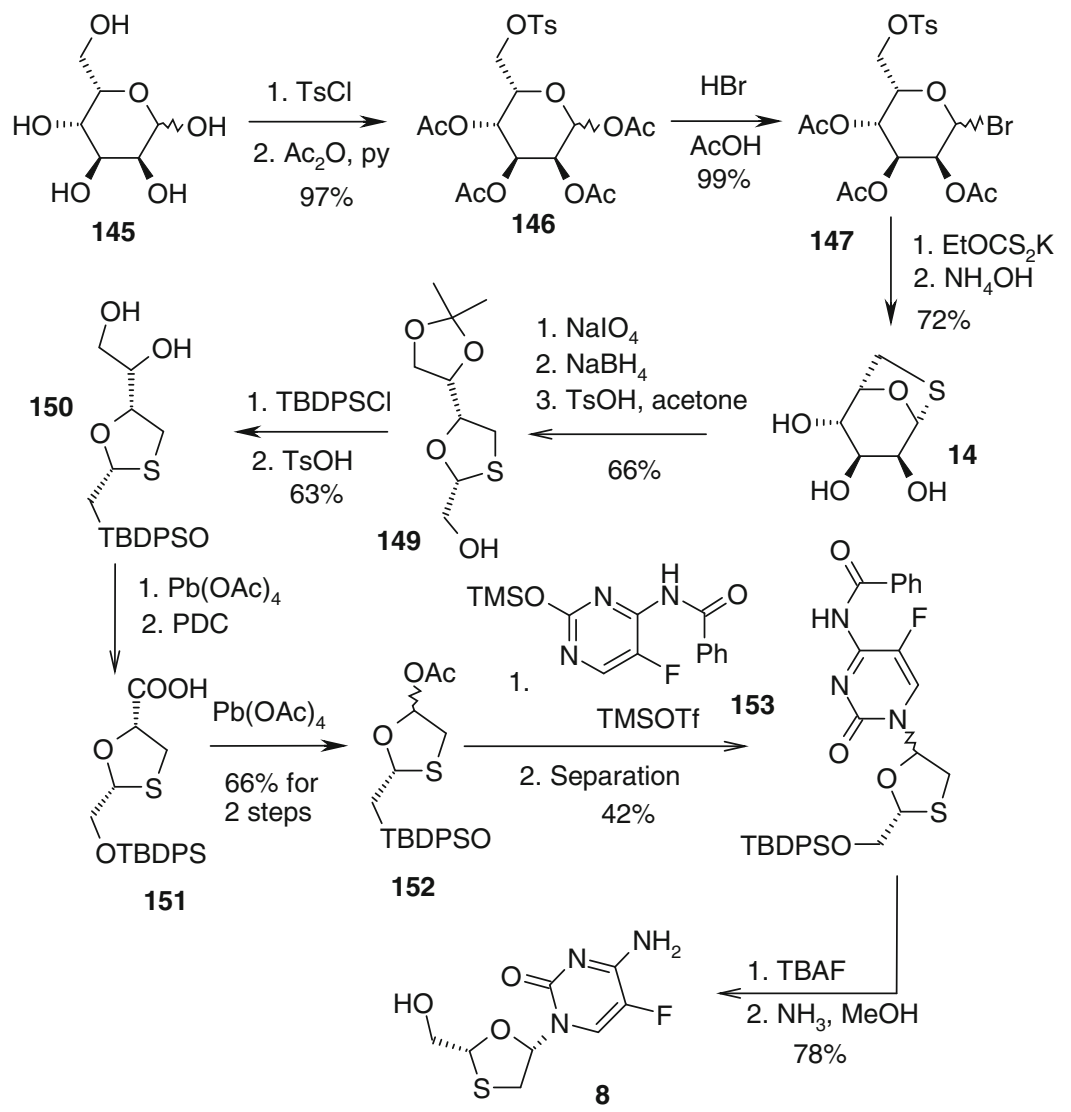

Scheme 35 Early synthesis of $\mathbf{8}$ 
approach starting from D-mannose or D-galactose was used for the preparation of D-enantiomer 125 [141].

Most of the methods describing the preparation of Emtricitabine (and Racivir) rely on the construction of 1,3-oxathiolane ring by reaction of glycolaldehyde or glyoxalic acid derivatives with mercaptoacetic acid or mercaptoacetic aldehyde (which exists as 1,4-ditiane 154). For example, one of the first of syntheses of this type commenced from allyl alcohol which was silylated and then subjected to ozonolysis to give glycolaldehyde derivative 155 (Scheme 36) [142]. Reaction of $\mathbf{1 5 5}$ with mercaptoacetic acid afforded 1,3-oxathiolane 156, which was reduced with $\mathrm{LiAlH}(\mathrm{O} t \mathrm{Bu})_{3}$ or DIBAL and then acetylated to form 157. Finally, reaction of $\mathbf{1 5 7}$ with silylated fluorocytosine derivative $\mathbf{1 5 8}$ followed by deprotection led to the formation of racemic $\mathbf{8}$ (Racivir).

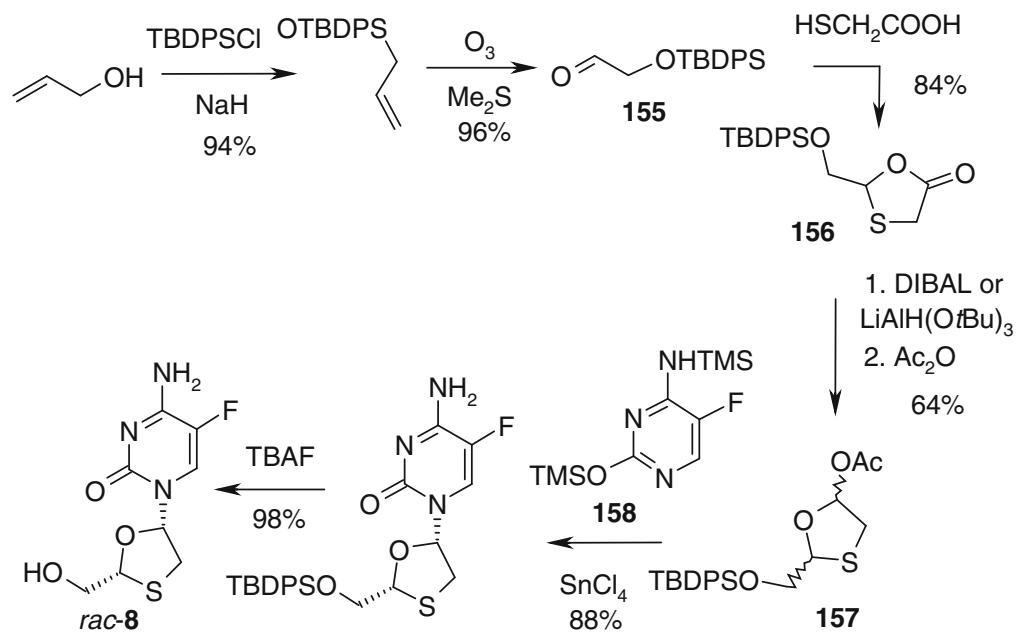

Scheme 36 Synthesis of racemic 8 (Racivir) patented by Emory University (Relative configurations are shown)

More than 15 preparations described in patents are variations of the above synthetic scheme. In particular, to obtain optically pure Emtricitabine, lipase-catalyzed enzymatic resolution, as well as chiral stationary phase HPLC was used [143]. However, the most effective procedure included separation of menthyl derivatives. This method evolved significantly since the first publication (which in fact relied on separation of all the 4 possible diastereomers) [144]; one of the recent multigram preparations is shown in the Scheme 37 [145]. The first step of the synthesis included formation of methyl ester $\mathbf{1 5 9}$ from glyoxalic acid and $L$-menthol. Reaction of $\mathbf{1 5 9}$ with 1,4-ditiane $\mathbf{1 5 4}$ gave 1,3-oxathiolane $\mathbf{1 6 0}$ as a mixture of cis diastereomers. 

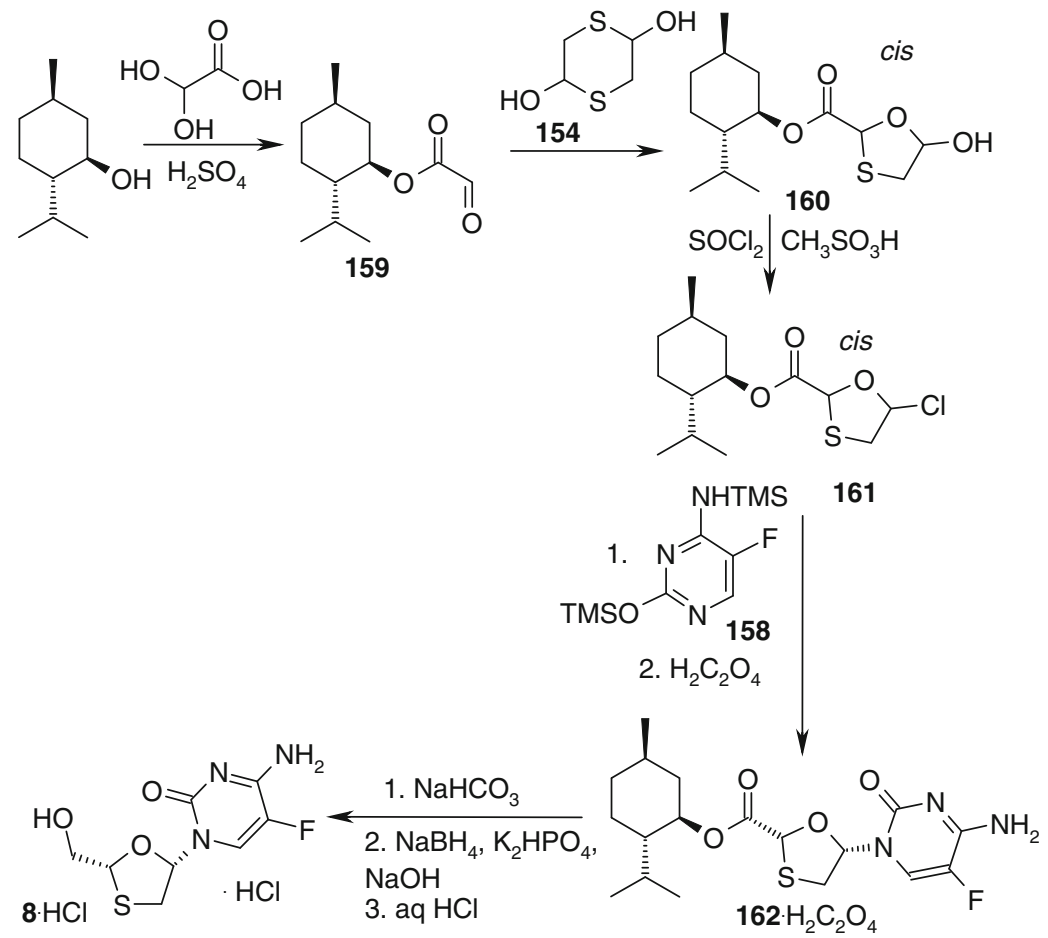

Scheme 37 One of the recent syntheses of Emricitabine (8)

Compound 160 was transformed to chloride 161 by treatment with thionyl chloride and methanesulfonic acid. Reaction of $\mathbf{1 6 1}$ and $\mathbf{1 5 8}$ led to the formation of $\mathbf{1 6 2}$, which was separated as a single diastereomer by transformation to oxalate and subsequent crystallization. Finally, reduction of $\mathbf{1 6 2}$ with $\mathrm{NaBH}_{4}$ gave Emtricitabine (8) which was isolated as hydrochloride.

An interesting variation of the method was patented by Glaxo Wellcome Inc [146]. Their synthesis was started from 2,4-dichloro-5-fluoropyrimidine (93) (Scheme 38). Reaction of $\mathbf{9 3}$ with NaOEt and then - with anion of 2,2-dimethoxyethanol gave pyrimidine derivative 163, which upon detection formed aldehyde 164. Reaction of $\mathbf{1 6 4}$ and $\mathbf{1 5 4}$ led to the formation of 1,3-oxathiolane 165, which was acetylated to give 166. Treatment of 166 with TMSOTf resulted in rearrangement leading to $\mathbf{1 6 7}$, which was transformed to racemic 8 (Racivir) by reaction with ammonia.

A number of methods for the preparation of Elvucitabine (126) were reported in the literature. In the first synthetic scheme developed in Yale University [147], 2 '-deoxy-5-fluoro- $\beta$-L-uridine (168), which is enantiomer of Floxuridine (4), was used as the key intermediate (Scheme 39). Compound 168 can be prepared in 
<smiles>CCON(C)O[Mg]C(C)C</smiles>

93<smiles>CCOc1nc(Cl)ncc1F</smiles><smiles>COC(CO)C(CO)N=O</smiles>

$69 \%$<smiles>CCOc1nc(OCC(OC)OC)ncc1F</smiles><smiles>CCOc1nc(OC[C@@H]2O[C@@H](O)CS2)ncc1F</smiles>

165<smiles>CCOc1nc(OCC=O)ncc1F</smiles><smiles>CCOc1nc(OC[C@@H]2O[C@H](C(C)=O)CS2)ncc1F</smiles>

Scheme 38 Synthesis of racemic 8 (Racivir) patented by Glaxo Wellcome Inc. (Relative configurations are shown)

several steps from L-arabinose. Mesylation of $\mathbf{1 6 8}$ followed by alkaline cyclization led to the formation of oxetane 169, which was transformed to cytidine derivative 170. Compound $\mathbf{1 7 0}$ was rearranged to 126 by treatment with $t$-BuOK in DMSO.

Synthesis of Elvucitabine (126) developed by chemists from Vion Pharmaceuticals commenced from lactone $\mathbf{1 7 1}$ (Scheme 40), which can be obtained in 4 steps from<smiles>CC(C)(O)[N+](=O)[O-]</smiles><smiles>Cc1cn(C2C[C@H]3O[C@@H]3C2)c(=O)[nH]c1=O</smiles>

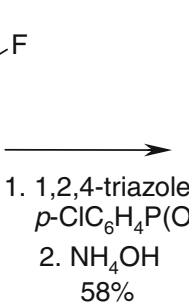<smiles>Nc1nc(=O)n([C@H]2C[C@H]3OC[C@H]3O2)cc1F</smiles><smiles>COC(=O)C[C@H]1C=C[C@H](n2cc(F)c(N)nc2=O)O1</smiles>

Scheme 39 Synthesis of Elvucitabine (126) developed in Yale University 
D-glutamic acid [148]. Phenylselenation of enolate generated from 171 proceeded highly diastereoselectively and led to $\mathbf{1 7 2}$.

Phenylselenide 172 was reduced with DIBAL and then acetylated to give acetate $\mathbf{1 7 3}$ as a mixture of anomers. Reaction of $\mathbf{1 7 3}$ with $\mathbf{1 5 8}$ was also
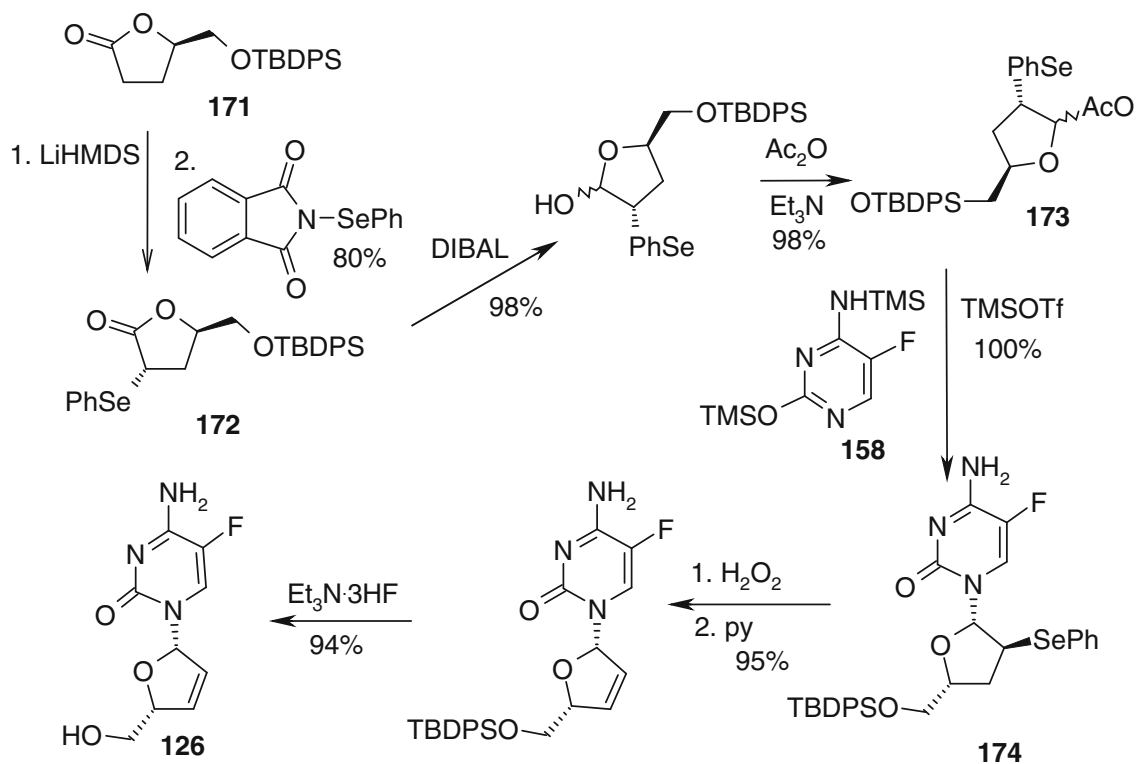

TMSOTf $100 \%$

Scheme 40 Synthesis of Elvucitabine (126) by Vion Pharmaceuticals

diastereoselective due to the steric effect of bulky phenylselenyl substituent and gave $\beta$ anomer 174 in almost quantitative yield. Oxidative elimination of the selenide substituent from $\mathbf{1 7 4}$ and subsequent deprotection gave Elvucitabine (126) as a single enantiomer. An analogous synthesis was described by chemists from Emory University [149].

Syntheses of Dexelvucitabine (127) [150] and later - Elvucitabine (126) [151] were described, starting from D- and L-xylose, respectively, both using almost the same methodology. In particular, D-xylose was transformed into the dibenzoyl derivative $\mathbf{1 8 1}$ using standard manipulations (Scheme 41). Under modified Appel conditions ( $\mathrm{I}_{2} / \mathrm{PPh}_{3} /$ imidazole), $\mathbf{1 8 1}$ gave unstable glycal 182, which reacted with fluorocytosine derivative $\mathbf{1 5 8}$ and $N$-iodosuccinimide to yield 183. Compound $\mathbf{1 8 3}$ was subjected to reductive elimination and deprotection to give $\mathbf{1 2 7}$.

Preparation of Dexelvucitabine (127) on a kilogram scale starting from 5-fluorocytidine (184) was developed by chemists from Pharmasset (Scheme 42) 


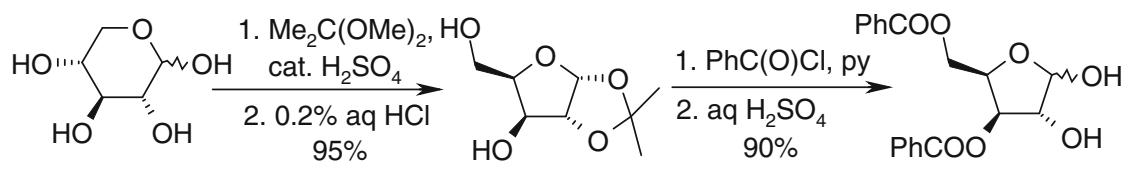

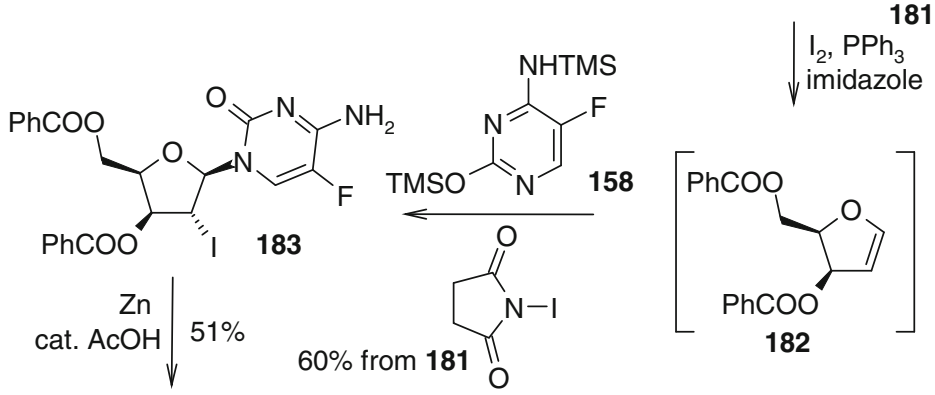<smiles>Nc1nc(=O)n([C@H]2C=CC(COOC(=O)c3ccccc3)O2)cc1F</smiles>

Scheme 41 Synthesis of Dexelvucitabine (127)

[152]. Compound 184 was subjected to bromoacylation with excess of 2-acetoxy-2methylpropionyl bromide (185) to give a mixture of esters 186 and $\mathbf{1 8 7}$. This mixture was subjected to reductive elimination to give $\mathbf{1 8 8}$, which was transformed to $\mathbf{1 2 7}$ upon alcoholysis.

Another synthesis of $\mathbf{1 2 7}$ relied on palladium mediated Ferrier rearrangementtype glycosidation of a furanoid glycal (Scheme 43) [153]. The initial steps of

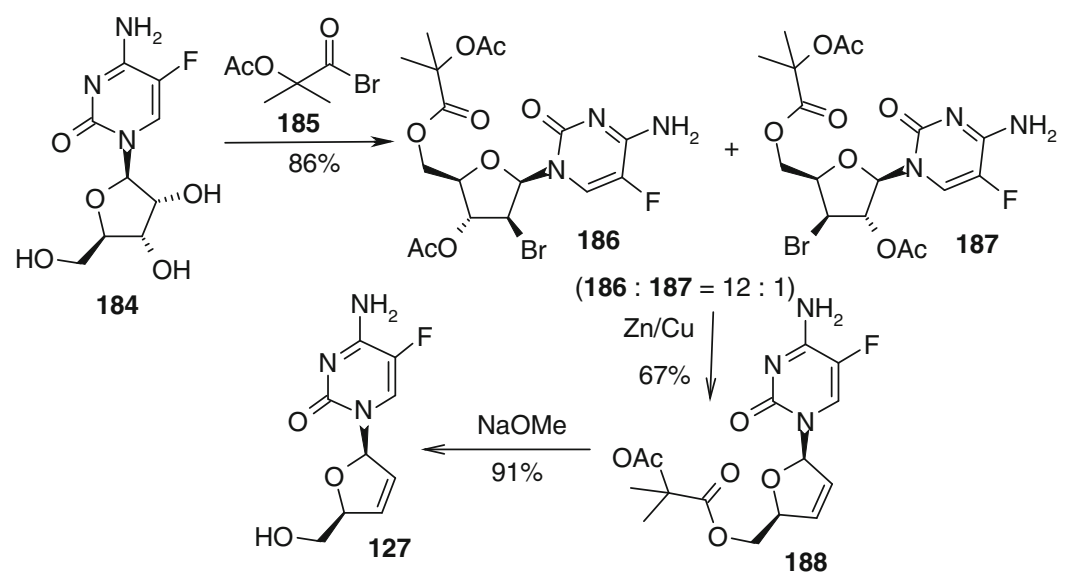

Scheme 42 Synthesis of Dexelvucitabine (127) by Pharmasset 
the synthesis were quite similar to those shown in Scheme 41. The major difference was the use of polymer-supported $\mathrm{PPh}_{3}$ at the glycal generation step, which allowed for isolation of unstable glycal $\mathbf{1 8 9}$ with more than $90 \%$ purity. Palladium-catalyzed reaction of $\mathbf{1 8 9}$ with 5-fluorocytosine (9) was accompanied by Ferrier-type rearrangement and led to derivative 190, which was transformed to $\mathbf{1 2 7}$ upon deprotection.

All the reported syntheses of DPC-961 (128) and DPC-963 (129) commenced from the corresponding $o$-amino- $\alpha, \alpha, \alpha$-trifluoroacetophenones 191 (Scheme 44).

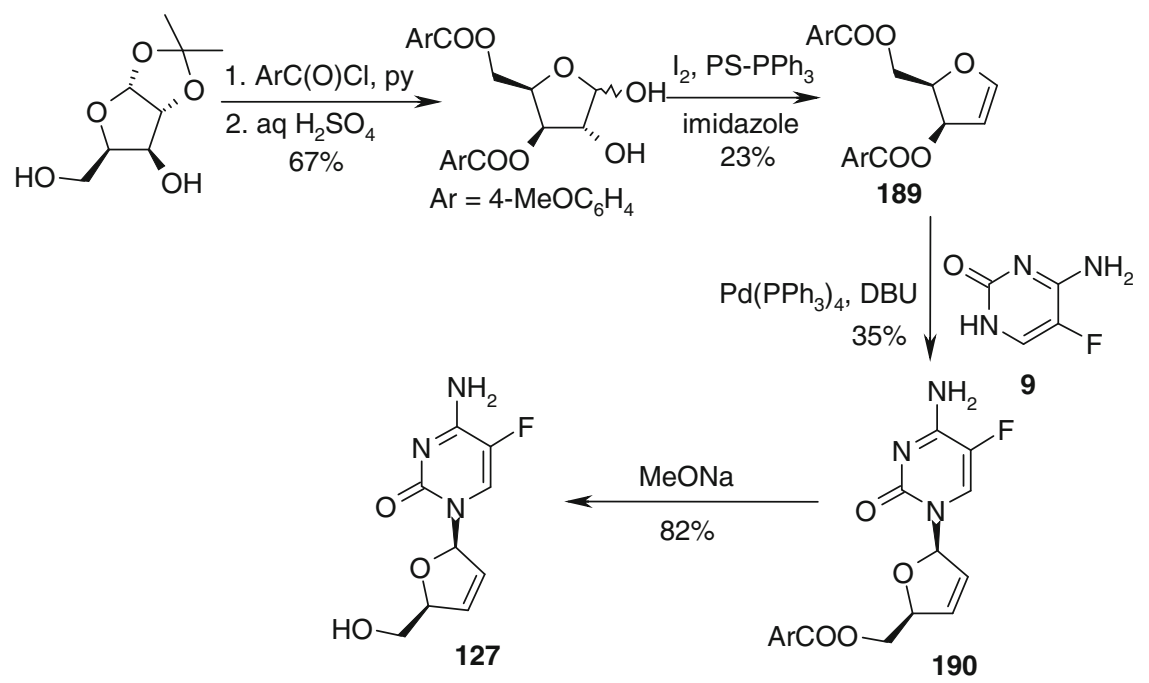

Scheme 43 Synthesis of Dexelvucitabine (127)

In the first preparations of $\mathbf{1 2 8}$ and $\mathbf{1 2 9}, \mathbf{1 9 1}$ reacted with TMSNCO to give adducts 192, which were transformed to cyclic imines 193 upon dehydratation. Reaction of 193 with lithium cyclopropylacetylenide gave racemic 128 and 129, which were subjected to chiral stationary phase HPLC to isolate $\mathbf{1 2 8}$ and $\mathbf{1 2 9}$ as pure enantiomers [136, 137]. Several improvements were reported for this synthetic scheme. In particular, diastereoselective additions of lithium cyclopropyl acetylenide to the derivatives of $\mathbf{1 9 3}$ containing residues of $\alpha$-phenylethyl amine or campheic acid were developed [154, 155]. Moreover, an enantioselective modification of this method employing amino alcohol 194 as an asymmetric catalyst was discovered [156,157]. Another enantioselective method involved reaction of the derivatives of $\mathbf{1 9 3}$ and cyclopropyl acetylene itself, catalysed by amino alcohol derivatives (e.g. 195) and $\mathrm{Zn}(\mathrm{OTf})_{2}$ [158].

DPC-083 (130) and DPC-082 (131) were obtained by reduction of $\mathbf{1 2 8}$ and 129, respectively, with $\mathrm{LiAlH}_{4}[136,137]$. Recently, an alternative approach to the synthesis 


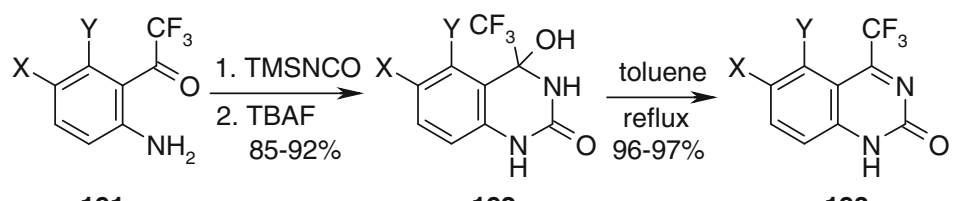

191

192

193<smiles>[X]c1ccc2c(c1[Y])C(C#CC1CC1)(C(F)(F)F)NC(=O)N2</smiles>
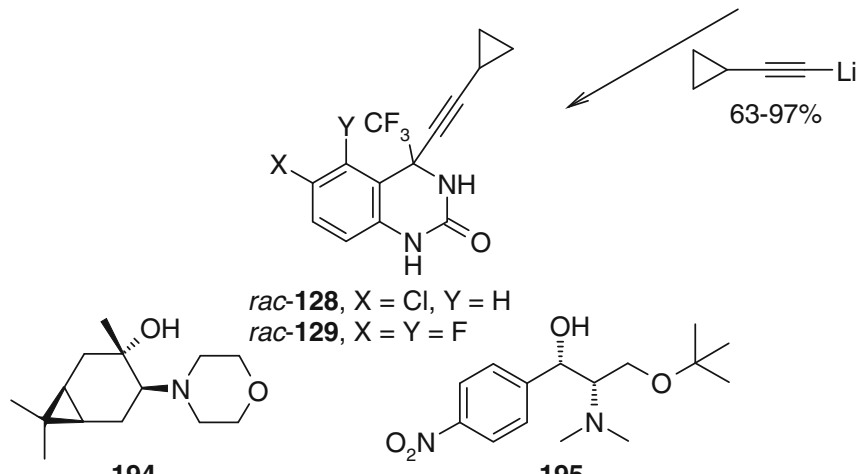

rac-128, $\mathrm{X}=\mathrm{Cl}, \mathrm{Y}=\mathrm{H}$ rac-129, $\mathrm{X}=\mathrm{Y}=\mathrm{F}$

194<smiles>CN(C)[C@H](COC(C)(C)C)[C@@H](O)c1ccc([N+](=O)[O-])cc1</smiles>

195

Scheme 44 Synthesis of DPC-961 (128) and DPC-963 (129)

of 130 was reported, which relied on enantioselective organocatalytic Mannich-type reaction of imine derivative 196 and cyclopropyl methyl ketone (Scheme 45) [159]. Although enantioselectivity of the key step was moderate (ee $75 \%$ ), it could be easily enhanced to $>99 \%$ by a single recrystallization of intermediate 197 .
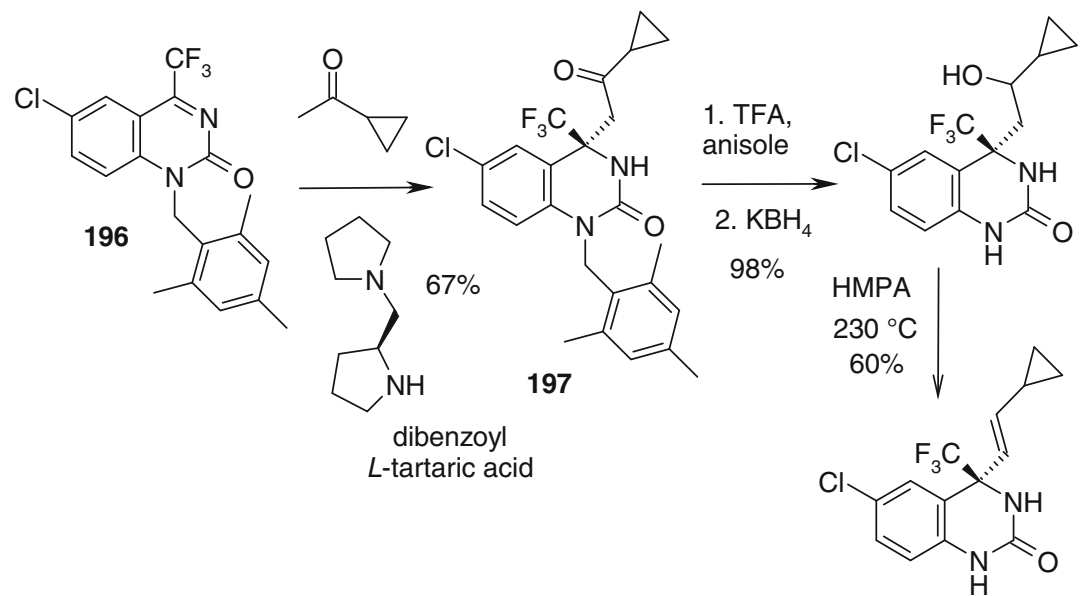

130

Scheme 45 Synthesis of DPC-083 (130) using organocatalytic Mannich-type reaction 


\subsection{Other Antiviral Agents}

Apart from anti-HIV drugs discussed in the previous section, two additional antiviral agents can be mentioned: Trifluridine (7) and Favipiravir (198). Trifluridine (7) was mentioned above as a component of Phase III investigational drug TAS-102. It is however more known as an ophthalmic anti-herpes agent launched by Glaxo Wellcome (now merged into GlaxoSmithKline) in 1980 [5]. It is effective against herpetic keratitis, and seems to be especially useful in 'difficult' cases [160]. High susceptibility to biodegradation of Trifluridine is advantageous for its use as ophthalmic drug, as its action in other tissues is thus prevented. As in the case of anti-tumor activity, the mechanism of antiviral action of $\mathbf{7}$ involves the inhibition of viral replication. Trifluridine does this by incorporating into viral DNA during replication, which leads to the formation of defective proteins and an increased mutation rate [161]. Inhibition of thymidylate synthetase also seems to contribute into antiviral effect of 7. The details of these processes, as well as synthesis of $\mathbf{7}$ were discussed in the above sections.

Favipiravir (198) has been discovered by Toyama Chemicals; it is currently in Phase III (Japan) and Phase II (USA) clinical trials [113, 162]. Favipiravir is under development as an agent against influenza virus, however, it was also tested against other RNA viruses, including arenaviruses, bunyaviruses, West Nile virus (WNV), yellow fever virus (YFV), and foot-and-mouth disease virus (FMDV) [163]. A proposed mechanism of action of $\mathbf{1 9 8}$ includes its biotransformation into ribofuranosyltriphosphate derivative 199 (Scheme 46), which inhibits influenza virus RNA polymerase in the host cells [164].

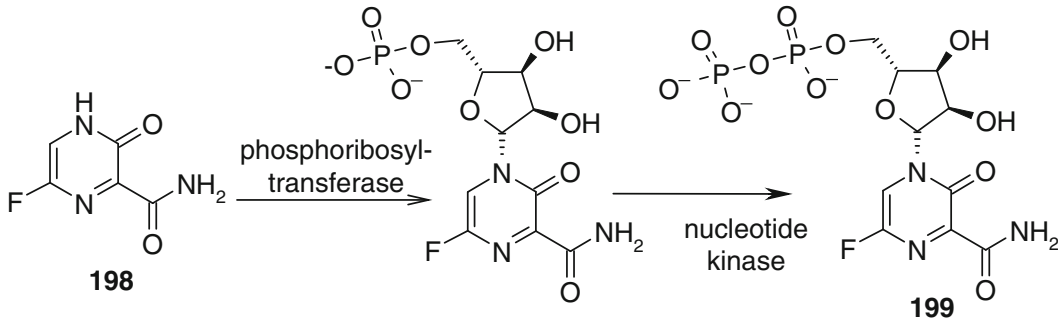

Scheme 46 A proposed pathway of Favipiravir (198) bioactivation

One of the syntheses of 198 is based on pyrazine $\mathbf{2 0 0}$ (Scheme 47) [165, 166]. Compound 200 was transformed to methoxy derivative 201 via diazotization step; 201 was then subjected to Buchwald - Hartwig amination to give 202. Ester 202 was transformed to amide 203; diazotization of $\mathbf{2 0 3}$ in the presence of pyridine hydrofluoride led to the formation of fluoro derivative 204. The last step of the synthesis included deprotection of the methyl ether to give $\mathbf{1 9 8}$. 
<smiles>COC(=O)c1nc(N)cnc1OC</smiles>

Scheme 47 Synthesis of Favipiravir (198) reported in 2002

Several syntheses of $\mathbf{1 9 8}$ involved difluoro derivative $\mathbf{2 0 5}$ as a key intermediate which was prepared in 4 steps from readily available materials (Scheme 48) [166, 167]. Acidic hydrolysis of $\mathbf{2 0 5}$ gave amide 206, which upon mild alkaline hydrolysis led to 198. Alternatively, compound 198 was obtained by mild alkaline hydrolysis of $\mathbf{2 0 5}$ followed by reaction with $\mathrm{H}_{2} \mathrm{O}_{2}-\mathrm{NaOH}$, or by reaction of $\mathbf{2 0 5}$ with allyl or benzyl alcohol, removal of the protection, and hydrolysis. Recently, an improved version of this method was patented, which allowed authors to claim its industrial applicability [168].

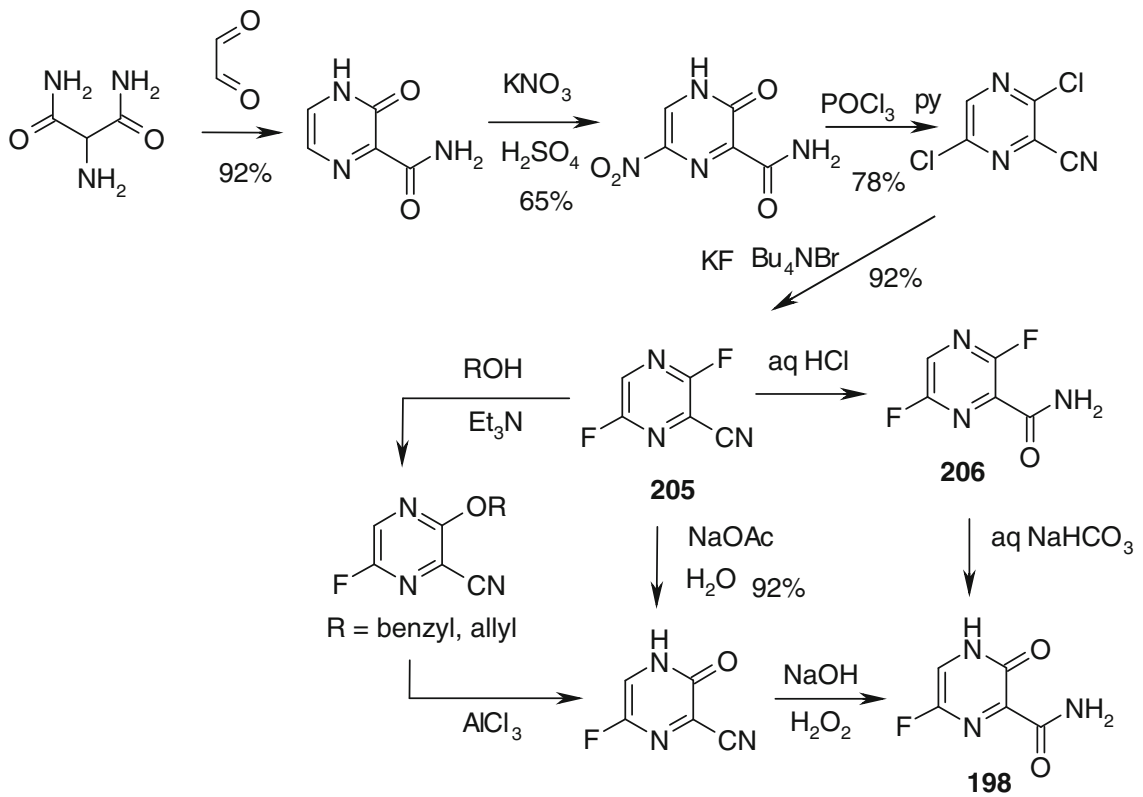

Scheme 48 Synthesis of Favipiravir (198) via the key intermediate 205 
One more method for the preparation of $\mathbf{1 9 8}$ commenced from pyrazine derivative 207, which was transformed to dichloride 208 using Sandmeyer reaction (Scheme 49) [166]. Hydrolysis of the ester moiety in $\mathbf{2 0 8}$ followed by one-pot chloroanhydride formation, introduction of fluorine atom and amination gave derivative 209, which was transformed into 198 by diazotization and subsequent hydrolysis.

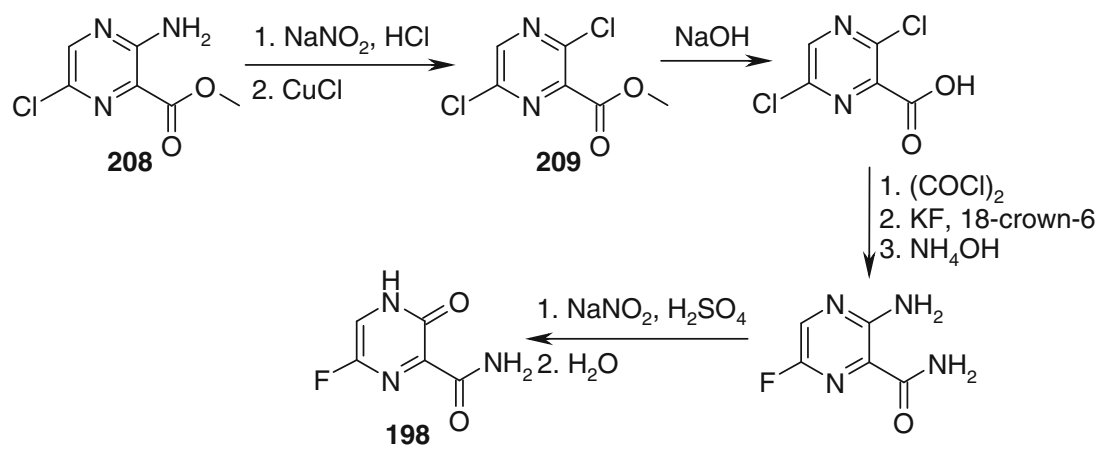

Scheme 49 Synthesis of Favipiravir (198) from pyrazine derivative 207

Several other approaches to the synthesis of Favipiravir were also described, most of them relying on direct fluorination of pyrazine derivatives with molecular fluorine [166] All they were low-yielding and allowed for the preparation of milligram quantities of the final product.

\subsection{Antibacterial Agents}

A single compound is discussed in this category, namely GSK-1322322 (210), which was developed by GlaxoSmithKline and has reached Phase II clinical trials in bacterial skin infections [113] and Phase III - in community-acquired bacterial pneumonia [169]. Compound $\mathbf{2 1 0}$ acts as an inhibitor of peptide deformylase - an enzyme that removes the formyl group during eubacterial peptide elongation. Bacterial protein synthesis initiates with formyl-methionyl-tRNA and, consequently, all polypeptides newly synthesized in bacteria contain an $\mathrm{N}$-formylmethionine terminus. This residue is further removed in two steps catalyzed by peptide deformylase and methionine aminopeptidase, respectively. Inhibition of peptide deformylase increase production of bacterial $N$-formylated polypeptide, which prevents bacteria growth and possibly triggers an enhanced immune response [170]. Peptide deformylase is a metalloprotease, which mostly utilizes $\mathrm{Fe}^{2+}$ in its active site. It was shown for analogs of $\mathbf{2 1 0}$ that $N$-formyl- $N$-hydroxylamine function coordinated to metal ion when the inhibitor was bound to the enzyme [171]. 
Synthesis of $\mathbf{2 1 0}$ was started from preparation of chiral diamine 211 (Scheme 50) [172]. In particular, $D$-serine methyl ester was converted to $N$-benzyl derivative 212, which was transformed into carboxylic acid 212 using reaction with chloroacetyl chloride and subsequent hydrolysis. Carboxylic acid $\mathbf{2 1 2}$ was subjected to coupling with benzyl amine, reduction, reaction with ethyl oxalyl chloride and reductive cyclization to give bicyclic compound 213. Finally, 211 Two-step reduction of 213 led to the formation of diamine 211, which was isolated as dihydrochloride. Reaction of $\mathbf{2 1 1}$ with dichloro derivative $\mathbf{2 1 5}$ and then - hydrazine hydrate gave the product 216, which was coupled with carboxylic acid $\mathbf{2 1 7}$ and subjected to catalytic hydrogenation to give $\mathbf{2 1 0}$.

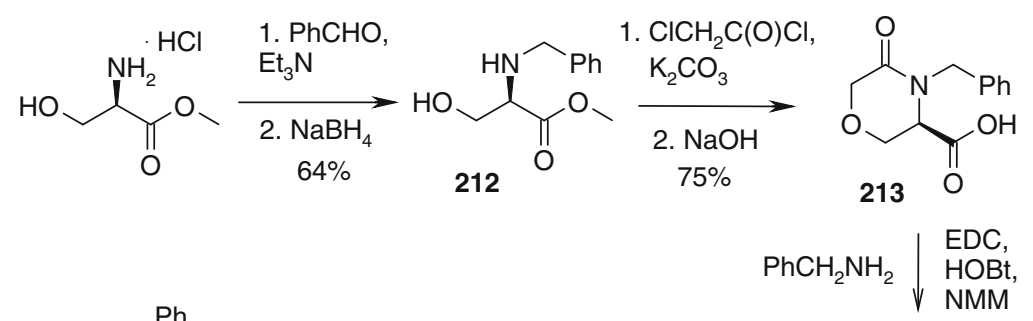

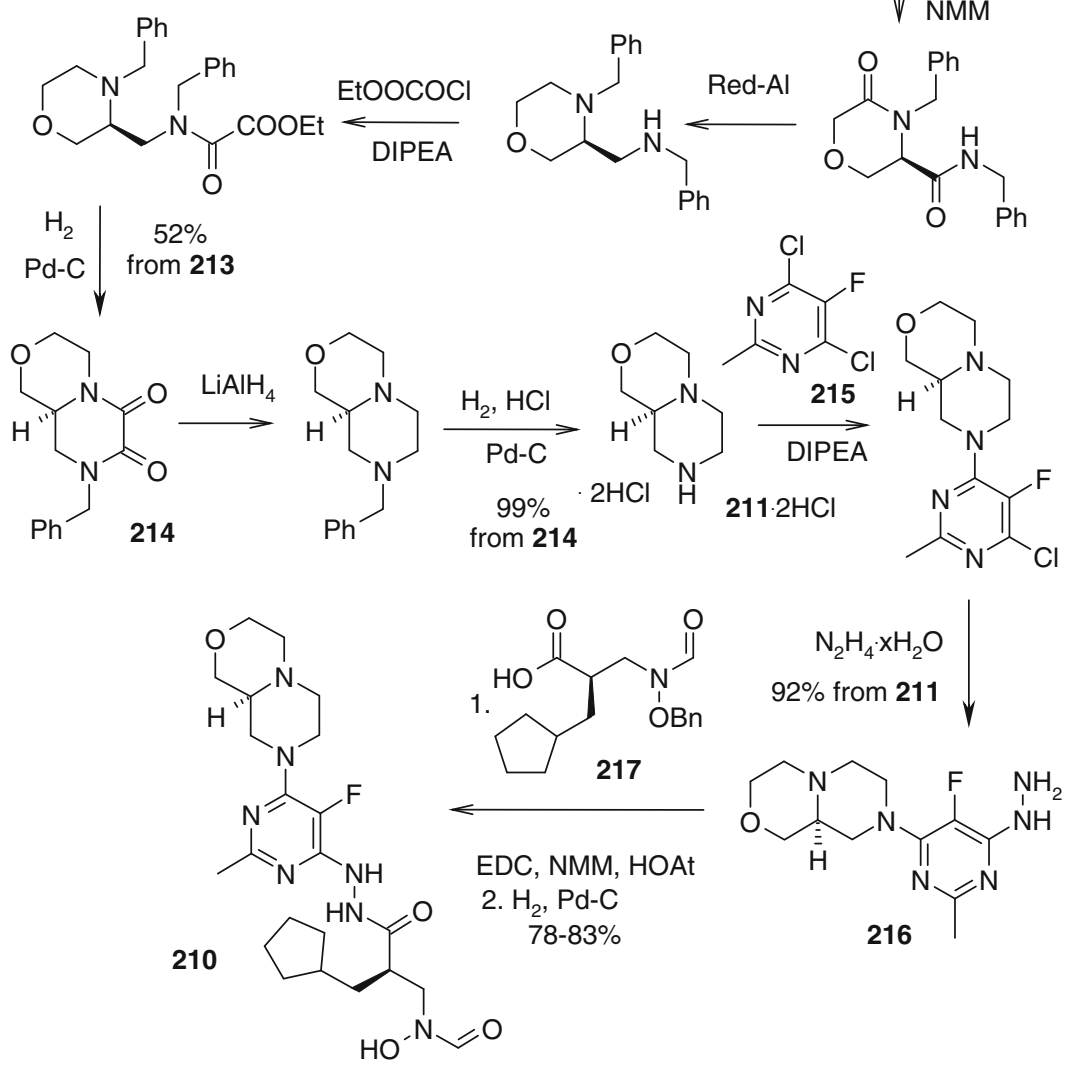

Scheme 50 Synthesis of GSK-1322322 (210) 
Fig. 6 Anti-fungal agents<smiles>Nc1nc(=O)[nH]cc1F</smiles>

9<smiles>CC(c1ncncc1F)[C@@H](C)[C@@H](Cn1cncn1)c1ccc(F)cc1F</smiles>

\subsection{Antifungal Agents}

Two drugs were launched as anti-fungal agents to date: Flucytosine (9) (Valeant, 1971) and Voriconazole (10) (Pfizer, 2002) (Fig. 6) [5]. Flucytosine itself has no antifungal activity; its activity results from the rapid conversion into Fluorouracil (1) within susceptible fungal cells [173]. The mechanism of cytotoxic effect of Fluorouracil has been discussed in the previous sections. Flucytosine is taken up by fungal cells by cytosine permease, which is the transport system for cytosine and adenine. Inside the fungal cells, $\mathbf{9}$ is deaminated to $\mathbf{1}$ by cytosine deaminase. The specificity of this step is crucial for the narrow antifungal spectrum of 9: mammalian cells as well as fungi lacking cytosine deaminase are not sensitive to $\mathbf{9}$. On the other hand, Fluorouracil itself cannot be used as an antifungal drug, since it is only poorly taken up by fungal cells and is too toxic to human cells.

The major drawback of Flucytosine is rapid development of resistance in fungi, either by mutations or by increased synthesis of pyrimidines; this limits the use of 9 as a single antifungal agent. Monotherapy with Flucytosine is currently only used in some cases of chromoblastomycosis and in uncomplicated candidosis; in all other cases, 9 is used together with other agents, usually Amphotericin B [173].

The effect of Voriconazole (10) is exerted within the fungal cell membrane. In particular, cytochrome P450-dependent 14- $\alpha$-lanosterol demethylase is inhibited, which prevents the conversion of lanosterol (217) to ergosterol (218) - an important component of yeast and fungal cell membranes which does not occur in mammalians (Scheme 51). This mechanism results in the accumulation of toxic methylsterols and inhibition of fungal cell growth and replication [174].

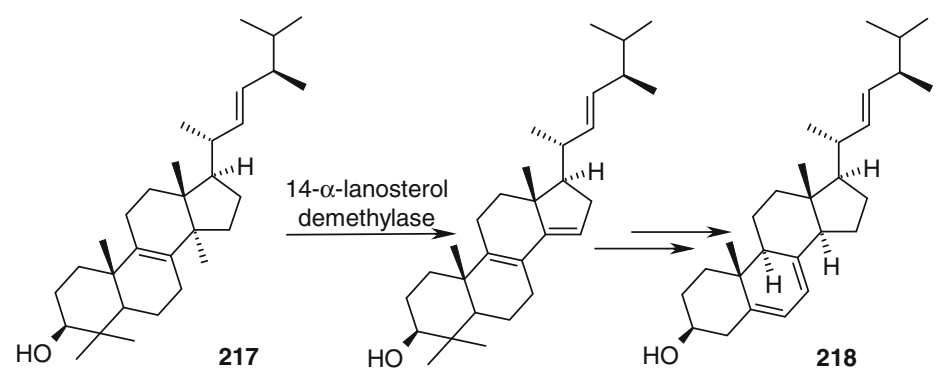

Scheme 51 Conversion of lanosterol (217) to ergosterol (218) 
Voriconazole is active against many fungal infections, including invasive aspergillosis, Pseudallescheria, Scedosporium, Fusarium infections [175]. It is also proposed for empirical antifungal therapy [176]. An important advantage of Voriconazole is high oral bioavailability (96\%). The most common side effect, which is unique for Voriconazole among other azole antifungals, is a reversible disturbance of vision (photopsia): it occurs in nearly a third of patients but rarely leads to discontinuation of the drug [174]. Resistance to Voriconazole still remains uncommon, although an increase of resistance and continued surveillance with greater use of the drug has been reported [177].

The first synthesis of Flucytosine (9) has been reported in 1957 [13, 14]. The synthetic scheme is quite similar to that for Fluorouracil (1); in the case of $\mathbf{9}$, compound 27 was subjected to reaction with $\mathrm{PCl}_{5}$ and then - liquid ammonia to give 219, which was transformed to 9 upon hydrolysis (Scheme 52). In an alternative method, compound $\mathbf{7 0}$ (prepared from Fluorouracil) reacted with $\mathrm{SOCl}_{2}$ to give 220, which was transformed to 9 upon reaction with ammonia in methanol [84]. Another synthesis commenced from 2,5-difluoro-4-chloropyrimidine, which, however, is not readily accessible [178]. Flucytosine was also obtained by direct fluorination of cytosine using $\mathrm{CF}_{3} \mathrm{OF}$ ( $85 \%$ yield) $[179,180]$, fluorine [181, 182], and AcOF [20].<smiles>[R5]c1ncc(F)c(=O)[nH]1</smiles><smiles>Nc1nc(=O)[nH]cc1F</smiles>

Scheme 52 Syntheses of Flucytosine (9)

Despite numerous syntheses of Voriconazole (10) were documented, they all followed the same synthetic strategy, namely, addition of anion $\mathbf{2 2 1}$ to ketone $\mathbf{2 2 2}$, followed by isolation of necessary diastereomeric pair and its resolution with 10-camphorsulphonic acid (Scheme 53). Three different approaches were used for the generation of anion $\mathbf{2 2 1}$ or the corresponding organometallic species. First of them relied on deprotonation of the pyrimidine derivative 222 (prepared from the fluorinated keto ester $\mathbf{2 2 3}$ or dichloro derivative $\mathbf{9 3}$ ) by strong bases such as LDA (Scheme 54) [183-189]. 


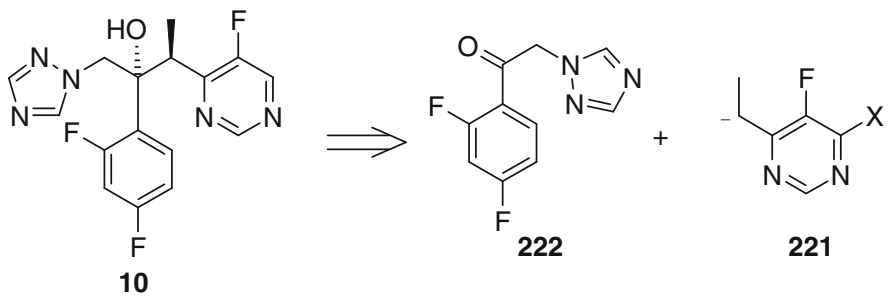

Scheme 53 Retrosynthetic analysis of Voriconazole (10)<smiles>CCOC(=O)C(F)C(=O)C(F)F</smiles>

224<smiles>CC(C)(C)C(O)(Cn1cncn1)c1ccc(F)cc1F</smiles><smiles></smiles><smiles>CCc1ncnc(Cl)c1F</smiles><smiles>[Mg][Te]</smiles>

2. 222<smiles>CC(c1ncnc(Cl)c1F)C(O)(Cn1cncn1)c1ccc(F)cc1F</smiles>

Separation

223 $26 \%$ from 223

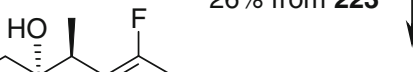

$\mathrm{H}_{2}$<smiles>CC(c1ncnc(Cl)c1F)C(O)(Cn1ncnn1)c1ccc(F)cc1F</smiles>

$\mathrm{AcONa}$ or Ni-Ra

$66 \%$

Scheme 54 Synthesis of Voriconazole (10) via intermediate 223

The main drawback of this method was low diastereoselectivity of the key step; therefore tedious separation of diastereomers was necessary. Another approach to generation of $\mathbf{2 2 1}$ relied on $\mathrm{ZnCl}_{2}$-catalyzed decarboxylation of salts 224, prepared from 225 (Scheme 55) [190]. In this case, the desired diastereomeric pair was obtained with much better selectivity $(6.5: 1)$. The last approach relied on Reformatsky-type reaction involving $\mathbf{2 2 2}$ and bromides $\mathbf{2 2 6}$ (prepared from 223 [191, 192] or its thio analogues [193-195]) or sulfonates 227 (prepared from 93) (Scheme 56) [196, 197]. In this case, good diastereoselectivities were obtained. 


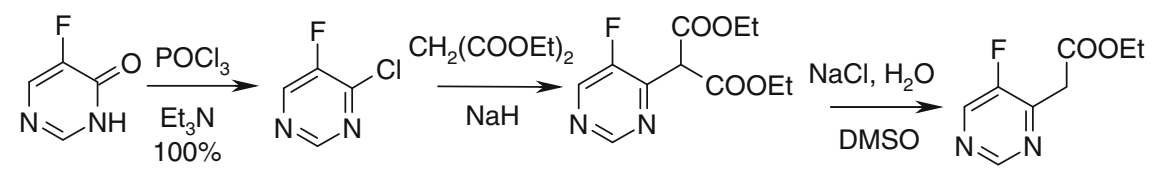
225<smiles>CCOC(C)c1ncncc1F</smiles>

Scheme 55 Synthesis of Voriconazole (10) via intermediate 224<smiles>CC(=O)c1nc(Cl)nc(Cl)c1F</smiles><smiles>CC(O)c1ncncc1F</smiles>

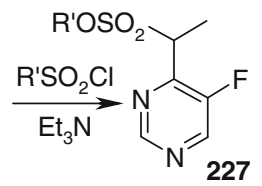

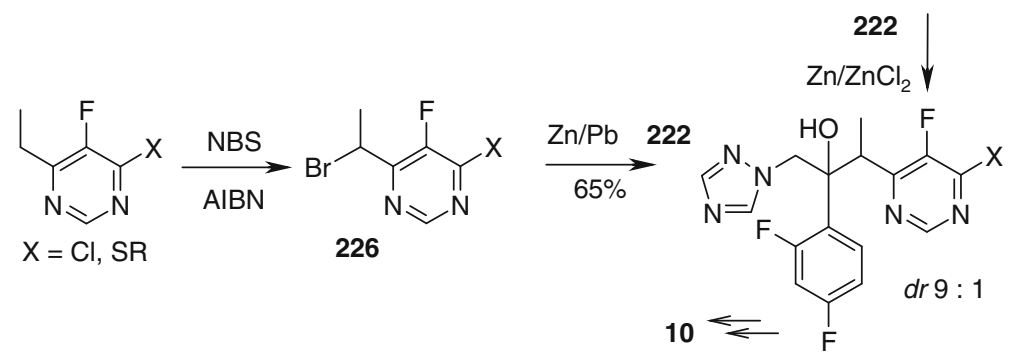

Scheme 56 Synthesis of Voriconazole (10) using Reformatsky-type reaction

\section{Agents Acting at Nervous System}

Seven compounds designed as agents acting at central and/or peripheral nervous system have reached at least Phase II clinical trials, and only one of them was launched (Table 4) [3, 113]. These compounds address different biological targets and act as skeletal muscle relaxants (Afloqualone (11)), antipsychotics (BMY-14802 (228), A-437203 (229), and JNJ-37822681 (230)), nootropic agents (BMY-21502 (231)) or analgesics (BW-BW-4030W92 (232) and GW-842166X (233)). 
Table 4 Derivatives of fluorinated diazines - nervous system modulators [3, 5, 115]

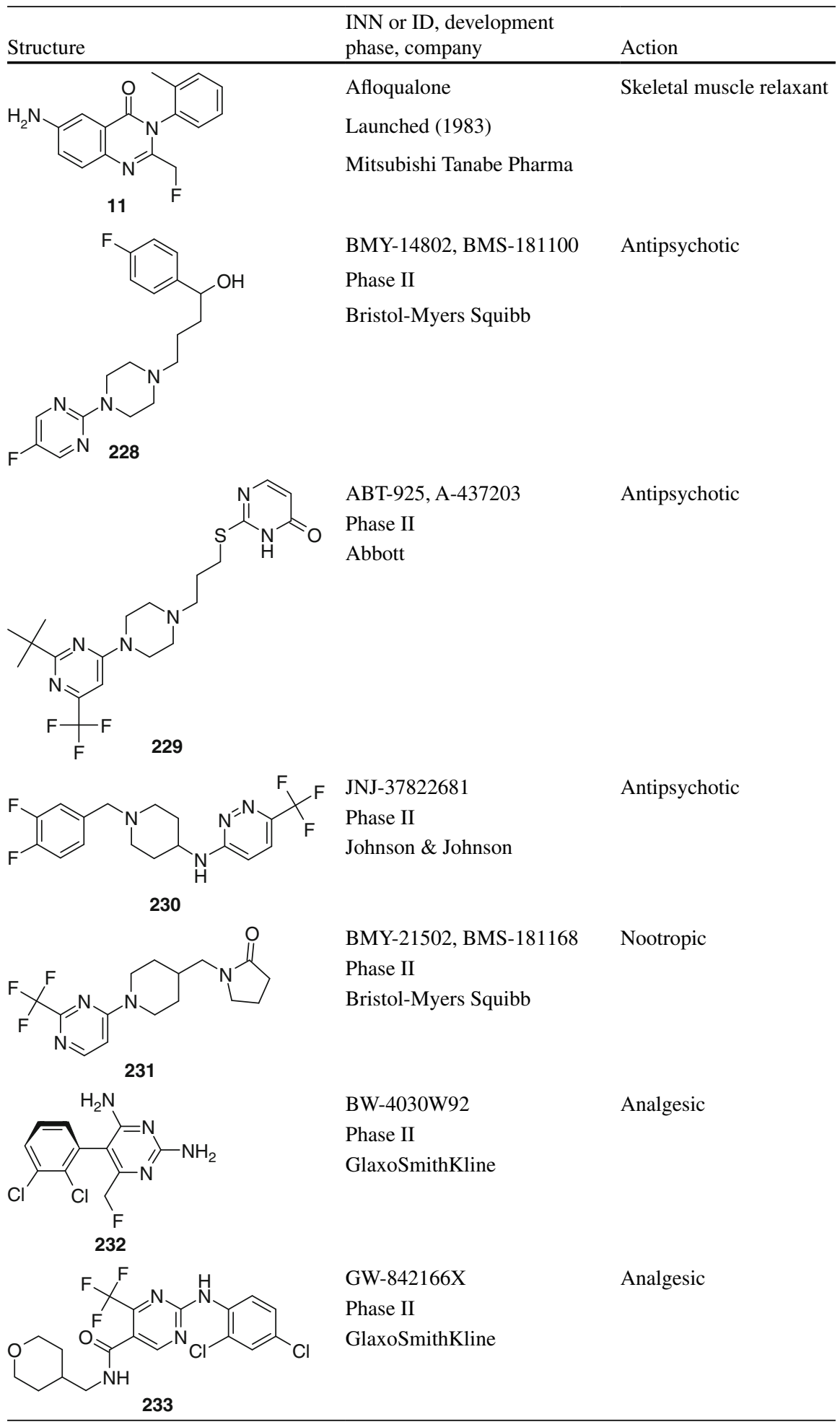


Fig. 7 Afloqualone (11) and Methaqualone (234)

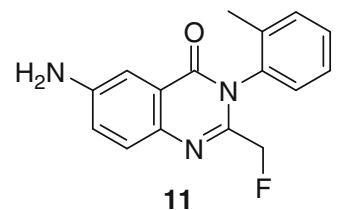

11<smiles>Cc1ccccc1-n1c(C)nc2ccccc2c1=O</smiles>

\subsection{Skeletal Muscle Relaxants}

A representative of fluorinated diazines, Afloqualone (11), was launched in 1983 in Japan as a central acting muscle relaxant [198]. It is an analogue of Methaqualone (234) (Fig. 7) - a drug widely used as a hypnotic, for the treatment of insomnia, and as a sedative and muscle relaxant in 1970s, but reclassified as a Schedule I controlled substance in USA in 1984 [199].

The mechanism of action of Afloqualone is not well studied. It was shown that its site of action is different from that of other central acting muscle relaxants, i.e. Mephenesin, Chlormesazone or Diazepam [200]. GABA-enhancing effect was also demonstrated [303]. The main routes of metabolism of 11 in human include $N$-acetylation, followed by hydroxylation at the $2^{\prime}$-methyl and acetyl methyl carbons, as well as glucuronidation of the aromatic amino group. This pattern of metabolism is similar to that observed in monkeys and rats, but drastically different from that in dogs [304].

Synthesis of Afloqualone commenced from 5-nitroanthranilic acid (235) which was transformed to amide $\mathbf{2 3 6}$ via the corresponding chloroanhydride (Scheme 57) [201]. Catalytic reduction of $\mathbf{2 3 6}$ followed by acetylation gave 237, which reacted with chloroacetyl chloride to form quinazoline 238. Nucleophilic substitution of chlorine atom in $\mathbf{2 3 8}$ with fluorine led to the formation of $\mathbf{2 3 9}$, which upon deprotection gave Afloqualone (11). Alternatively, compound 236 was subjected to acylation with fluoroacetyl chloride or anhydride to give amide $\mathbf{2 4 0}$ [202]. Refluxing of 240 with acetic anhydride gave quinazoline 241, which was reduced to Afloqualone either by catalytic hydrogenation or using $\mathrm{SnCl}_{2}$.

\subsection{Antipsychotics}

All three compounds discussed in this section (i.e. 228-230) have reached Phase II clinical trials as agents for treatment Schizophrenia. Development of BMY-14802 (228) was discontinued more than 10 years ago. For ABT-925 (229), Phase II trials were terminated in 2011; for JNJ-37822681 (230), the latest clinical study was completed in February 2012 [113]. Despite the disease addressed by 228-230 is common, the compounds express their effect through interactions with different biological targets. In particular, BMY-14802 (228) developed by Bristol-Myers Squibb acts as a dual antagonist of $\sigma_{1}$ and 5-HT $1 \mathrm{~A}$ receptors. However, it should be 
<smiles>Cc1ccccc1N</smiles><smiles>Cc1ccccc1NC(=O)c1cc([N+](=O)[O-])ccc1N</smiles><smiles>CC(=O)Nc1ccc(N)c(C(=O)Nc2ccccc2C)c1</smiles><smiles>CCC(C)(C)O[Na]</smiles><smiles>[Y][13C](C)Br</smiles><smiles>CC(C)O[Na]</smiles><smiles>CC(=O)Nc1ccc2nc(CCl)n(-c3ccccc3C)c(=O)c2c1</smiles><smiles>[Y][V]</smiles><smiles>[Z10]c1ccc2nc(CF)n(-c3ccccc3C)c(=O)c2c1</smiles><smiles>CC(=O)Nc1ccc2nc(CF)n(-c3ccccc3C)c(=O)c2c1</smiles>

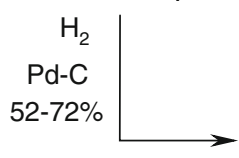<smiles>Cc1ccccc1-n1c(CF)nc2ccc(N)cc2c1=O</smiles>

$\mathrm{HCl}$ $\mathrm{MeOH}$ $62 \%$

Scheme 57 Synthesis of Afloqualone (11)

noted that relative role of these two targets in biological effect of $\mathbf{2 2 8}$ was debated in the literature. Whereas in pigeons, the effect was serotonergically mediated primarily through 5- $\mathrm{HT}_{1 \mathrm{~A}}$ receptors [203], in other model systems, these interactions did not seem to contribute significantly to the potential antipsychotic action of the compound [204]. Although studies in animal models supported for the suggestion that BMY-14802 (228) may possess antipsychotic properties [205], clinical trials showed lack of efficacy in Schizophrenia treatment [206]. 
Fig. 8 The structure of Olanzapine

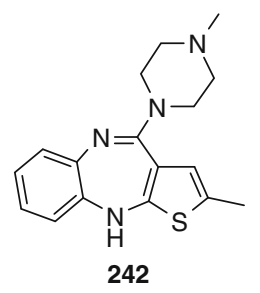

Recently, BMY-14802 was proposed as a promising candidate for clinical trials of $L$-DOPA-induced dyskinesia - a common side effect observed during prolonged use of $L$-DOPA in Parkinson disease patients [207]. It was shown that the compound suppresses abnormal involuntary movements related to $L$-DOPA-induced dyskinesia via its $5-\mathrm{HT}_{1 \mathrm{~A}}$ agonistic effect.

ABT-925 (229) developed by Abbott is a selective D3 receptor antagonist [208]. It was suggested that selective antagonists of D3 receptor might be promising antipsychotic agents lacking the presumed D2 receptor-mediated side effects, although D3 antagonists may express their effect via mechanisms that cannot be reflected by the commonly used animal models [209]. It was shown that ABT-925 produced cognitive signals but did not achieve sufficient D3 receptor occupancy at the doses used in clinical studies [210]. Nevertheless, these studies allowed for the assumption that the development and clinical testing of newer D3 receptor antagonists with higher potency at D3 receptors, enabling sufficient receptor occupancy, is highly warranted [211].

On the contrary, JNJ-37822681 (230) is a D2 highly selective receptor antagonist and hence acts in a mode analogous to that of most marketed antipsychotics [212]. JNJ-37822681 is characterized by a rapid dissociation rate from the dopamine D2 receptor, which was hypothesized to confer antipsychotic efficacy and improved tolerability [213]. Clinical studies in patients with an acute exacerbation of schizophrenia showed that JNJ-37822681 had similar biological activity but lesser tendency to induce weight gain compared to a known antipsychotic drug, Olanzapine (242) [214] (Fig. 8).

Synthesis of BMY-14802 (228) commenced from pyrimidine derivative 243 which reacted with piperazine $\mathbf{2 4 4}$ to give derivative $\mathbf{2 4 5}$ (Scheme 58) [215, 216]. Reduction of the compound 245 followed by deprotection gave amine 246, which was alkylated with chloride $\mathbf{2 4 7}$ and then subjected to acidic hydrolysis to form ketone 248. Reduction of 248 allowed BMY-14802 (228) to be obtained. Pure enantiomers of $\mathbf{2 2 8}$ were also obtained. To achieve this, the following methods were used: resolution of $\mathbf{2 2 8}$ with using reaction with $\alpha$-phenylethyl isocyanate [217] or lipase-catalyzed acetylation or hydrolysis [218], alkylation of $\mathbf{2 4 5}$ with enantiopure alcohols 249 [219]; and microbial reduction [305] or Ru-catalyzed enantioselective hydrogenation [220] of $\mathbf{2 4 8}$. 
<smiles>[R16]c1cnc(Cl)nc1SSC</smiles><smiles>OC(CCCCl)c1ccc(F)cc1</smiles>
249 (both enantiomers)

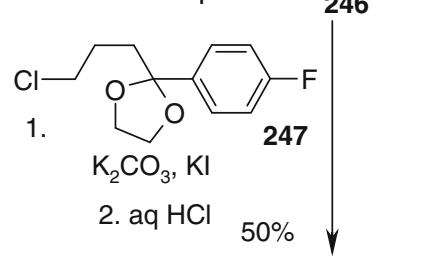

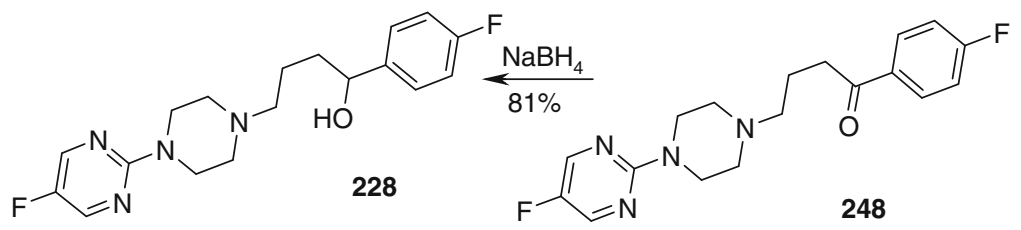

Scheme 58 Synthesis of racemic BMY-14802 (228)

ABT-925 (229) was obtained starting from amidine 250 and ethyl trifluoroacetoacetate to give pyrimidine $\mathbf{2 5 1}$ (Scheme 59) [221]. Reaction of $\mathbf{2 5 1}$ with $\mathrm{SOCl}_{2}$ and then - piperazine led to the formation of amine 252. Selective alkylation of $\mathbf{2 5 2}$ with 1-bromo-3-chloropropane gave chloride $\mathbf{2 5 3}$, which reacted with thiouracil anion to form ABT-925 (229).

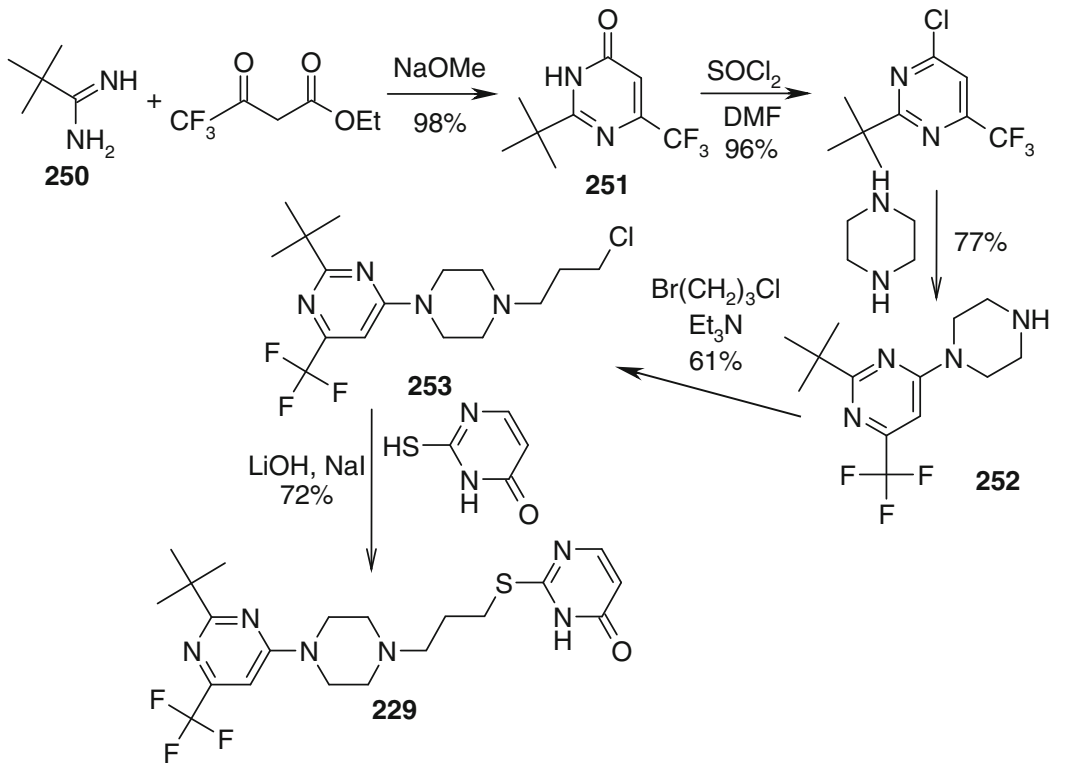

Scheme 59 Synthesis of ABT-925 (229) 
Synthesis of JNJ-37822681 (230) was quite trivial and relied on selective functionalization of 4-aminopiperidinecore, firstwith3-chloro-6-trifluoromethylpyridazine (254) and then - with 3,4-difluorobenzaldehyde (Scheme 60) [222].

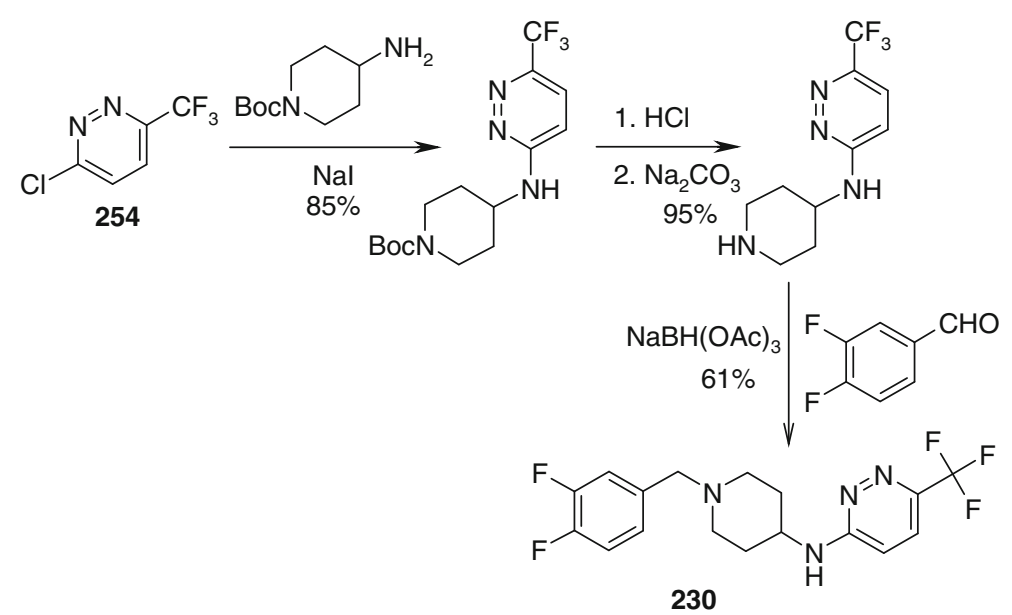

Scheme 60 Synthesis of JNJ-37822681 (230)

\subsection{Nootropic Agents}

BMY-21502 (231) was developed by Bristol-Myers Squibb as nootropic agent (i.e. for cognition disorders) and has reached Phase II clinical studies. The compound was effective in vitro [223] as well as in animal models [223-227, 306] that may predict cognitive enhancement. The mode of action of BMY21502 is poorly understood. It was shown that the compound has an anti-anoxic action, and activation of the CNS cholinergic system is involved as one of the causative mechanisms for this effect [228]. Clinical trials showed that BMY21502 was not significantly superior to placebo in Alzheimer's disease; moreover, although generally well tolerated, 231 also had a higher rate of discontinuations [229, 230].

Synthesis of BMY-21502 (231) optimized for large scale preparations commenced from malonodiamide and ethyl trifluoroacetate, which reacted to give pyrimidine 255 (Scheme 61) [231]. Compound 255 was transformed into dichloro derivative 256 upon treatment with $\mathrm{POCl}_{3}$. Reaction of 256 with piperidine 257 (prepared from 4-pyridinylmethyl chloride in two steps) gave 258, which was reduced catalytically to form BMY-21502 (231). Alternatively, BMY-21502 was obtained by arylation of $\mathbf{2 5 7}$ with 4-chloro-2-trifluoromethylpyrimidine (259) [232]. 


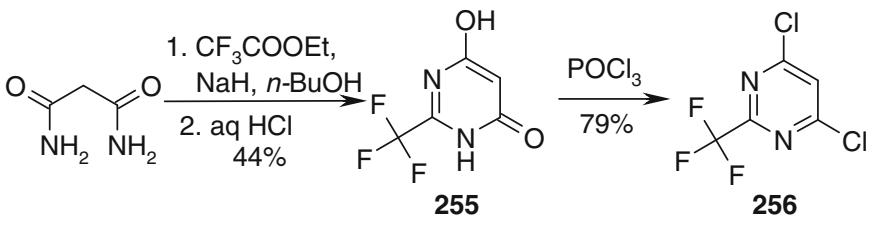

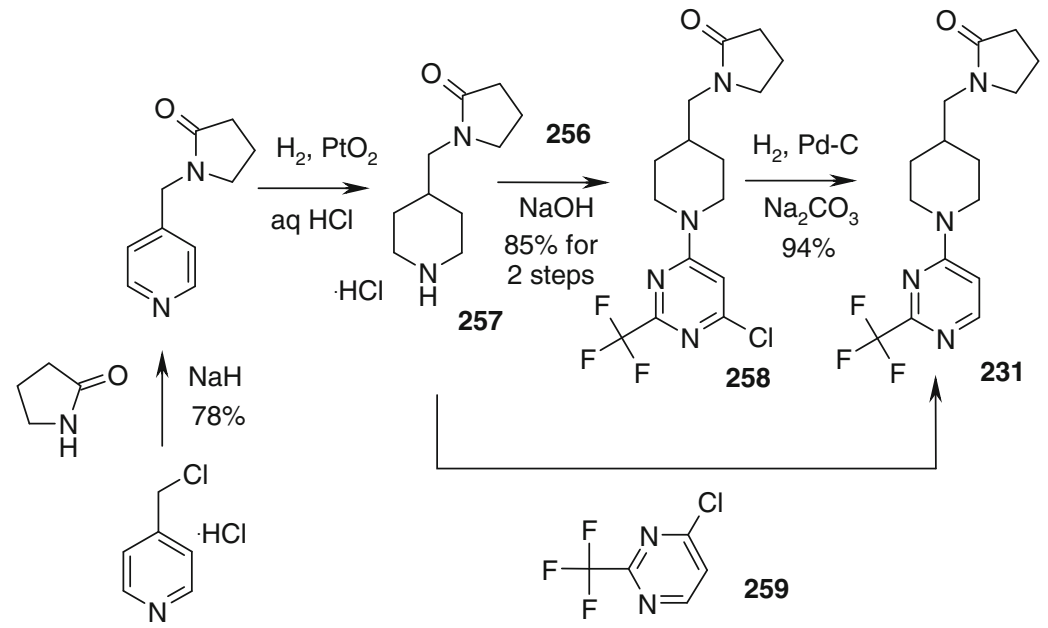

Scheme 61 Synthesis of BMY-21502 (231)

\subsection{Analgesics}

Both the compounds discussed in this section, i.e. BW-4030W92 (232) and GW 842166X (233), were developed by GlaxoSmithKline. Development of BW-4030W92 was discontinued in 2002; the latest Phase II clinical studies of GW-842166X were completed in 2009 [113]. BW-4030W92 (232) was developed as a CNS-acting antihyperalgesic agent (i.e. for treatment of increased sensitivity to pain). It is an analogue of anticonvulsant drug Lamotrigine (260) (Fig. 9), used $\mathrm{n}$ the treatment of epilepsy and bipolar disorder [233]. Like Lamotrigine, BW-4030W92 binds to the transmembrane segment S6 in domain IV of $\alpha$ subunit of voltage-gated sodium channels $\left(\mathrm{Na}_{\mathrm{v}}\right)$, thus acting as a pore blocker [234]. It is assumed that neuropathic pain is partially mediated by an increase in the density of $\mathrm{Na}_{\mathrm{V}}$ channels in injured axons and their dorsal root ganglions. Clinical studies in patients with chronic neuropathic pain showed that although BW-4030W92 significantly lowered allodynia severity at the first day, the effect did not maintain in further treatment [235].

GW-842166X (233) is a selective CB2 receptor full antagonist which has potent analgesic, anti-inflammatory and anti-hyperalgesic actions. It was selected as a clinical candidate after lead optimization of a pyrimidine ester 261 (GK02076, Fig. 9), identified in a focused screen as a partial agonist at the CB2 receptor with 

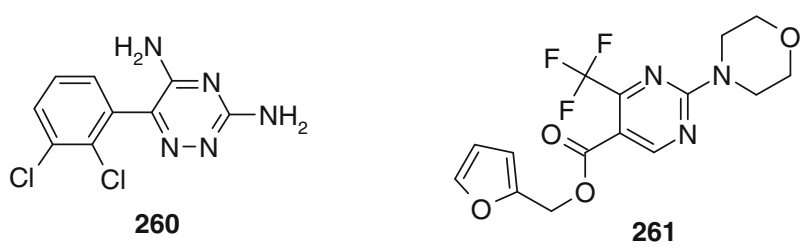

Fig. 9 The structures of Lamotrigine (260) and GK02076 (261)

micromolar potency [236]. The compound was evaluated as an analgesic for treatment of inflammatory pain (Phase I trials) and dental pain (Phase II trials) [113]. In the latter study, single doses of GW842166 failed to demonstrate clinically meaningful analgesia in the setting of acute dental pain [237].

Synthesis of BW-4030W92 (232) started from 2,3-dichlorobenzaldehyde (262) which was transformed into nitrile 263 (Scheme 62) [238]. Compound 263 which reacted with ethyl diethoxyacetate $-t$-BuOK and then - ethyl iodide to give enol ether 264. Reaction of $\mathbf{2 6 4}$ with guanidine afforded pyrimidine derivative $\mathbf{2 6 5}$, which upon deprotection gave aldehyde 266. Compound 266 was reduced with sodium borohydride and then subjected to reaction with diethylaminosulphur<smiles>CCO/C(=C(/N)c1cccc(Cl)c1Cl)C(OCC)OCC</smiles><smiles>CCO/C(CF)=C(\C#N)c1cccc(Cl)c1Cl</smiles><smiles>NC([NH2+])=[W][Mg]</smiles><smiles>CCOC(OCC)c1nc(N)nc(N)c1-c1cccc(Cl)c1Cl</smiles><smiles>Nc1nc(N)c(-c2cccc(Cl)c2Cl)c(CF)n1</smiles>

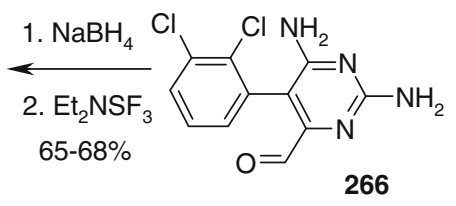

Scheme 62 Synthesis of racemic BW-4030W92 (rac-232) 
trifluoride (DAST) to give racemic $\mathbf{2 3 2}$. Alternatively, nitrile $\mathbf{2 6 3}$ reacted with ethyl fluoroacetate $-t$-BuOK and then - ethyl iodide to give enol ether 267, which was transformed to racemic $\mathbf{2 3 2}$ by reaction with guanidine. Resolution of enantiomers of $\mathbf{2 3 2}$ was achieved by crystallization of dibenzoyl- $L$-tartaric acid salt; the more active $R$-enantiomer was isolated.

In the synthesis of GW-842166X (233), commercially available pyrimidine $\mathbf{2 6 8}$ reacted with 2,4-dichloroaniline to give ester $\mathbf{2 6 9}$, which was subjected to hydrolysis followed by amide coupling with 4-aminomethyltetrahydropyran (270) to afford 233 (Scheme 63) [236, 239, 240].<smiles>COC(=O)c1cnc(Cl)nc1C(F)(F)F</smiles>

268

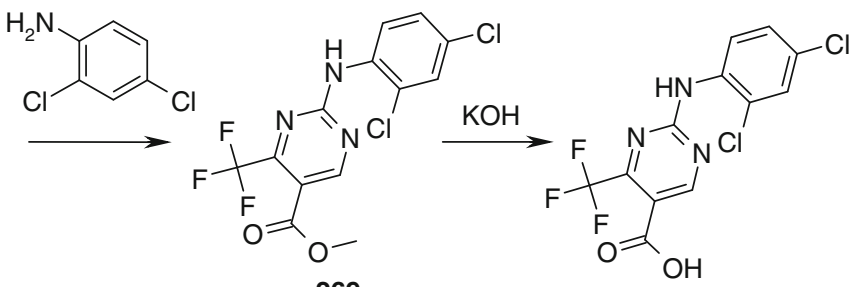

269<smiles>NCC1CCOCC1</smiles>

Scheme 63 Synthesis of GW-842166X (233)

\section{Other Classes}

In the previous sections, compounds targeting cancer cells or nervous system, as well as those fighting foreign organisms were discussed.

Three compounds do not fall into any of these categories. Fostamatinib disodium (88) was mentioned above as an anti-cancer investigational drug, but it was also studied as agent for autoimmune diseases, i.e. rheumatoid arthritis (currently in Phase III) and autoimmune thrombocytopenia (in Phase II). Gemigliptin (12) was approved as an anti-diabetic drug in South Korea in 2012. PF-04634817 (271) was discontinued after Phase I studies as an agent for liver fibrosis; nevertheless, it is currently investigated in diabetic nephropathy (Fig. 10) (Phase II, October 2012) [113]. 
<smiles>N[C@@H](CC(=O)N1CCc2c(nc(C(F)(F)F)nc2C(F)(F)F)C1)CN1CC(F)(F)CCC1=O</smiles>

12<smiles>CO[C@@H]1COCC[C@H]1N[C@H]1CC[C@@](C(=O)N2C[C@H]3CC[C@H]2CN3c2cc(C(F)(F)F)ncn2)(C(C)C)C1</smiles>

271

Fig. 10 The structure of Gemigliptin (12) and PF-04634817 (271)<smiles></smiles><smiles>CN(C)C(=N)NC(=N)N</smiles>

274

Fig. 11 The structures of Methotrexate (272), Sitagliptin (273) and Metformin (274)

As it was mentioned in the previous sections, the active principle of Fostamatinib disodium (88) is Tamatinib (92), which is formed by enzymatic hydrolysis of $\mathbf{8 8}$ in the intestine. As in the case of lymphoma, the effect of $\mathbf{8 8}$ in autoimmune diseases is related to inhibition of Spleen tyrosine kinase (Syk) by 92 [241, 242]. As Syk has the central role in transmission of activating signals within B cells, inhibition of this enzyme lowers expression of a number of proinflammatory cytokines and hence leads to immunosuppression [243]. Fostamatinib has shown significant efficacy in the treatment of patients with rheumatoid arthritis not responding to Methotrexate (272) (a drug which is used conventionally in therapy), although a number of adverse events were observed [244]. If these results are confirmed once Phase III studies are completed, it may find a place in the treatment of patients with rheumatoid arthritis with poor response to conventional therapy (Fig. 11). 
Gemigliptin (12) was developed by LG Life Sciences as an inhibitor of dipeptidyl peptidase 4 (DPP-4) - a target of oral drugs used to treat used to treat type 2 diabetes (characterized by high blood glucose in the context of insulin resistance and relative insulin deficiency) [245]. The first representative of this class, Sitagliptin (273) was launched in 2006. In human body, Gemigliptin is metabolized to LC15-0636, which is a major active metabolite, by cytochrome P450 3A4 isozyme [246]. Inhibition of DPP-4 results in increase of incretin levels (which is normally inactivated by DPP-4), in particular glucagon-like peptide-1 (GLP-1) and gastric inhibitory peptide (GIP) [247]. Incretins inhibit glucagons release and stimulate insulin secretion, which leads to decrease in glucose blood levels. Clinical trials showed efficacy and safety of Gemigliptin administered once daily as a monotherapy, [248] as well as in addition to Metformin (274) [249] for type 2 diabetes patients.

PF-04634817 (271) is a Phizer's investigational drug, initially developed as agent for liver fibrosis - formation of excess fibrous connective tissue in liver [250]. The development of the compound was discontinued since February 2012 after Phase I trials. Recently, a Phase II study of PF-04634817 in diabetic nephropathy a progressive kidney disease caused by angiopathy of capillaries in the kidney glomeruli [251] - was registered [113]. PF-04634817 is an antagonist of chemokine receptors (i.e. CCR2 and CCR5) [252]. These chemokine receptors are important players in the trafficking of monocytes/macrophages and in the functions of other cell types relevant to pathogenesis of many diseases [253], including liver fibrosis [307] and diabetic nephropathy [254].

Gemigliptin (12) was prepared by a convergent synthesis involving key intermediates 275, 276 and 277 (Scheme 64) [255]. Compound 275 was obtained by Swern oxidation of $\beta$-amino acid derivative 278. Both $\mathbf{2 7 6}$ and $\mathbf{2 7 7}$ were prepared starting from $N$-Boc-3-piperidone 279. In particular, 279 reacted with diethylaminosulfur trifluoride (DAST) to give difluoro derivative $\mathbf{2 8 0}$. Ru-catalyzed oxidation of $\mathbf{2 8 0}$ led to the formation of amide 281, which was subjected to ring-opening with $\mathrm{NaOMe}$ and then acidic deprotection to give hydrochloride 276. To obtain 277, $\mathrm{N}$-Boc-3-piperidone was deprotonated and then acylated with ethyl trifluoroacetate to give $\beta$-diketone $\mathbf{2 8 2}$. Reaction of $\mathbf{2 8 2}$ with trifluoroacetamidine followed by deprotection afforded 277. Further step of the synthesis included reductive amination of aldehyde 275 with amine 276, which was accompanied with piperidone ring formation to give 283. Full deprotection of $\mathbf{2 8 3}$ followed by selective protection of the amino group gave carboxylic acid $\mathbf{2 8 4}$, which was coupled with amine $\mathbf{2 7 7}$ to afford Boc derivative 285. Finally, deprotection of $\mathbf{2 8 5}$ led to the formation of Gemigliptin (12).

Synthesis of optically active PF-04634817 (271) based on commercially available (-)-Vince Lactam as chirality source. Starting from (-)-Vince Lactam the chiral key 4-amino-2-cyclopentene-1-carboxylic acid derivative $\mathbf{2 8 6}$ was synthesized. The compound 286 is dimethyl pyrrole protected form of corresponding aminoacid, which was subjected to amide coupling with Boc-protected diamine 287 to give 


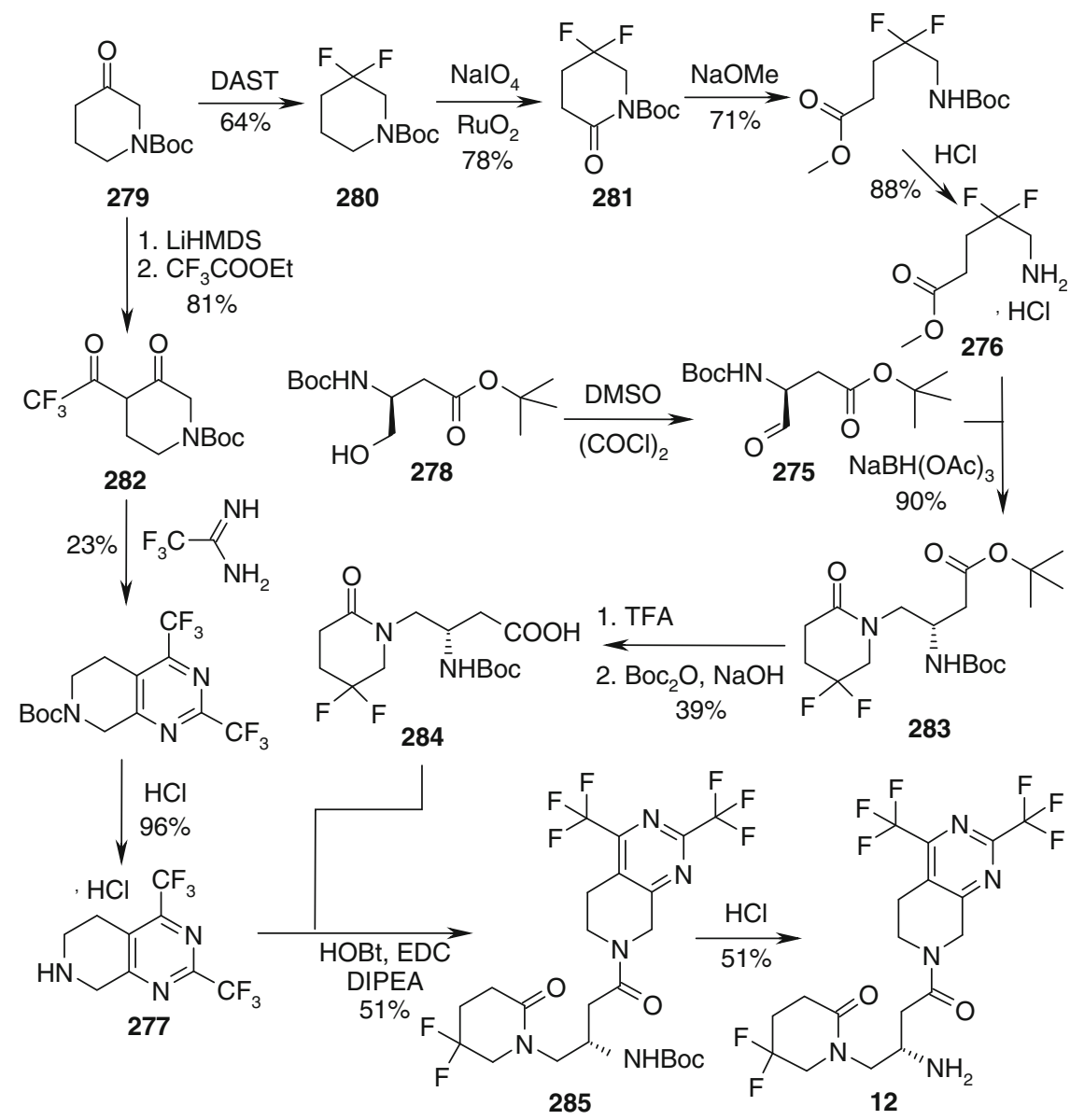

Scheme 64 Synthesis of Gemigliptin (12)

amine 288 (Scheme 65) [252]. Removing of the pyrrole function followed by catalytic hydrogenation gave amine $\mathbf{2 8 9}$, which was subjected to reductive amination of ketone 290, separation of diastereomers, deprotection and then - arylation with pyrimidine derivative 291 to afford the final product, 271.

\section{Fluorine-Containing Diazines in Agrochemistry}

Agrochemistry is one of more important field of application of the fluorinated compounds which is widely recognized [256, 257]. Eleven derivatives of fluorinecontaining diazines are agrochemicals: 8 compounds (292-299) are herbicides; 


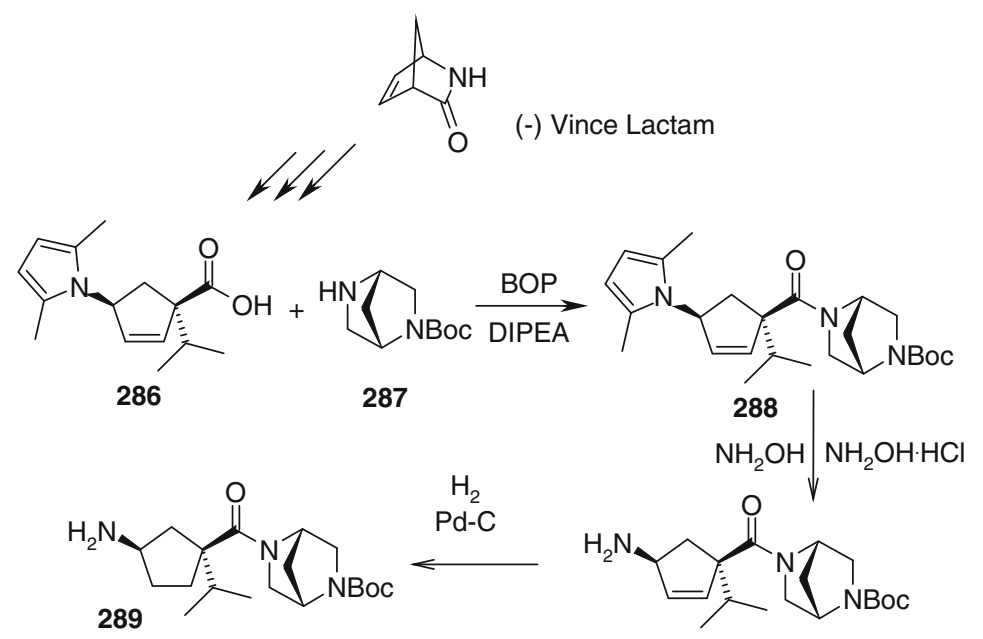<smiles>COC1COCCC1=O</smiles><smiles>COC1COCCC1NC1CCC(C(=O)N2CC3CC2C[N+]3(C)C(C)C)(C(C)C)C1</smiles><smiles>[Y]OC(=O)[C@@]1(C(C)C)CC[C@@H](N[C@H]2CCOC[C@H]2OC)C1</smiles>

Scheme 65 Synthesis of PF-04634817 (271)

Fluoxastrobin (300) is a fungicide, Fluacrypyrim (301) - an acaricide, and Flufenerim (302) is currently under development as an insecticide (Fig. 12).

\section{Herbicides}

\subsection{Protoporphyrinogen Oxidase Inhibitors}

Uracil derivatives Butafenacil (292, Inspire ${ }^{\circledR}$, Rebin $®$ ) and Benzfendizone (293) were introduced as herbicides in 1998, whereas their pyridazine-derived analogue Flufenpyr-ethyl (295) - in 2000 [258]. Butafenacil (developed by Syngenta 
<smiles>C=CCOC(=O)C(C)(C)OC(=O)c1cc(-n2c(=O)cc(C(F)(F)F)n(C)c2=O)ccc1Cl</smiles>

Butafenacil (292)<smiles>CC(C)N(C)S(=O)(=O)NC(=O)c1cc(-n2c(=O)cc(C(F)(F)F)n(C)c2=O)c(F)cc1Cl</smiles>

Suflufenacil (294)<smiles>[X]c1cccc([X])c1NS(=O)(=O)c1nc2cc(F)nc(OCC)n2n1</smiles>

Cloransulam-methyl (296), $\mathrm{X}=\mathrm{Cl}, \mathrm{Y}=\mathrm{COOMe}$ Diclosulam (297), $\mathrm{X}=\mathrm{Y}=\mathrm{Cl}$<smiles>COC(=O)c1ccccc1S(=O)(=O)NC(=O)Nc1nc(OC(F)F)cc(OC(F)F)n1</smiles>

Primisulfuron-methyl (299)<smiles>CCc1ccc(COc2ccc(-n3c(=O)cc(C(F)(F)F)n(C)c3=O)cc2)c(OC(C)C(=O)OC)c1</smiles><smiles>CCOC(=O)COc1cc(-n2ncc(C(F)(F)F)c(C)c2=O)c(F)cc1Cl</smiles>

Flufenpyr-ethyl (295)<smiles>COc1ncc(F)c2nc(S(=O)(=O)Nc3c(F)cccc3F)nn12</smiles>

Florasulam (298)<smiles>CON=C(C1=NOCCO1)c1ccccc1Oc1ncnc(Oc2ccccc2Cl)c1F</smiles>

Fluoxastrobin (300)<smiles>COC=C(C(=O)OC)c1ccccc1COc1cc(C(F)(F)F)nc(OC(C)C)n1</smiles>

Fluacrypyrim (301)<smiles>CC(F)c1ncnc(NCCc2ccc(OC(F)(F)F)cc2)c1Cl</smiles>

Flufenerim (302)

Fig. 12 Agrochemicals derived from fluorine-containing diazines

AG) is used for weed control in grapes, nut crops, pome and stone fruits and also as a cotton defoliant [259]. It was registered in Australia and approved by U. S. environmental protection agency. Benzfendizone (developed by FMC Corporation) is a post-emergence herbicide that provides good control of grass and broadleaf weeds in tree fruits and vines, as a cotton defoliant, and in total vegetation control [256]. Flufenpyr-ethyl (developed by Sumitomo Chemical 
Company) was registered in USA for use on corn, soybeans and sugarcane [259]. The most recent example is Saflufenacil (294, Kixor $\left.{ }^{\circledR}\right)$, introduced by BASF in 2009 for preplant burndown and selective PRE dicot weed control in multiple crops, including corn. [260].

Compounds 292-295 act as inhibitors of protoporphyrinogen oxidase (Protox) - an enzyme in the chloroplasts of the plant cells that oxidizes protoporphyrinogen IX (303) to produce protoporphyrin IX (304) (Scheme 66) [261]. In turn, 304 is a precursor molecule for both chlorophyll and heme. When protoporphyrinogen oxidase is inhibited, protoporphyrinogen IX is accumulated and transferred from chloroplasts into the cytoplasm, where non-enzymatic conversion of 303 to 304 occurs. When present in cytoplasm, $\mathbf{3 0 4}$ is cytotoxic due to interaction with oxygen upon action of light, which results in formation of singlet $\mathrm{O}_{2}$ molecules. ${ }^{1} \mathrm{O}_{2}$ causes lipid peroxidation, membrane disruption and plant cell death.

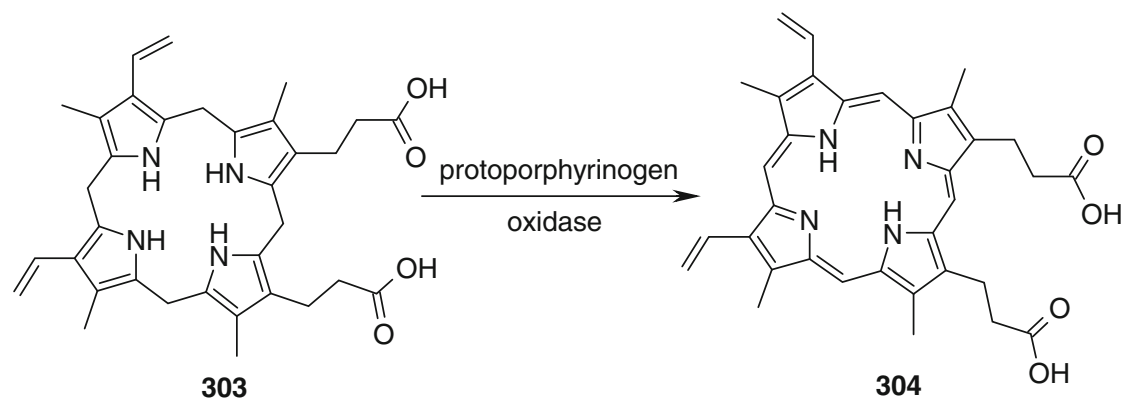

Scheme 66 Biological role of protoporphyrinogen oxidase

Butafenacil is known to be eye, skin and respiratory tract irritant in humans [262]. It also demonstrated very high toxic effect to algae, and moderate toxicity to fish, aquatic invertebrates and honeybees. For Benzfendizone and Flufenpyr-ethyl, no reports on toxic effects are available. Acute mammalian toxicology studies of Saflufenacil indicate that herbicide has low toxicity for mammals after ingestion, dermal exposure or inhalation. It is not an irritant for eyes and skin and does not act as a sensitizer.

Studies of the structure-activity relationship (SAR) of uracile derivatives as protox inhibitor showed that presence of a polyfluorinated alkyl group at position 6 of the uracil ring critical. Alkyl groups such as methyl at position 6 of the uracil ring resulted in compounds with low or no biological activity [263].

Limited data are available on the synthesis of Butafenacil (292). In particular, it was prepared by esterification of carboxylic acid 305, [264] as well as by reaction of isocyanate $\mathbf{3 0 6}$ with ester $\mathbf{3 0 7}$ (Scheme 67) [265]. Preparation of neither $\mathbf{3 0 5}$ nor 306 was disclosed in the corresponding patents, although synthesis of carboxylic acid $\mathbf{3 0 5}$ was partially described elsewhere [266]. 
<smiles>Cn1c(C(F)(F)F)cc(=O)n(-c2ccc(Cl)c(C(=O)O)c2)c1=O</smiles>
305

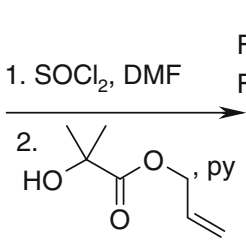<smiles>C=CCOC(=O)C(C)(C)OC(=O)c1cc(-n2c(=O)cc(C(F)(F)F)n(C)c2=O)ccc1Cl</smiles><smiles>C=CCOC(=O)C(C)(C)OC(=O)c1cc(N=C=O)ccc1Cl</smiles>

306

Scheme 67 Syntheses of Butafenacil (292)

Benzfendizone (293) was obtained from ethyl trifluoromethylaminocrotonate (308) which reacted with isocyanate 309 in the presence of $\mathrm{NaH}$ and then directly methylated to give 310 (Scheme 68) [267]. Demethylation of phenol moiety in 310 followed by alkylation with benzyl chloride $\mathbf{3 1 1}$ gave Benzfendizone.<smiles>CCOC(=O)/C=C(\N)C(F)(F)F</smiles>

308<smiles>COc1ccc([N+](=O)[O-])cc1</smiles>

309<smiles>COc1ccc(-n2c(=O)cc(C(F)(F)F)n(C)c2=O)cc1</smiles>

311<smiles>CCc1ccc(COc2ccc(-n3c(=O)cc(C(F)(F)F)n(C)c3=O)cc2)c(OC(C)C(=O)OC)c1</smiles>

Scheme 68 Synthesis of Benzfendizone (293)

The synthesis of Saflufenacil (294) is similar to Benzfendizone synthesis, but on the key step of uracile formation instead of isocyanate corresponding urethane $\mathbf{3 1 6}$ was used in basic conditions. Starting amine $\mathbf{3 1 5}$ was obtained in 3 steps from acid 
312. The final step of Saflufenacil formation is alkylation by $\mathrm{Me}_{2} \mathrm{SO}_{4}$ in phase transfer conditions (Scheme 69) [268].<smiles>CC(C)N(C)S(N)(=O)=O</smiles><smiles>CC(C)N(C)S(=O)(=O)NC(=O)c1cc(I)c(F)cc1Cl</smiles>

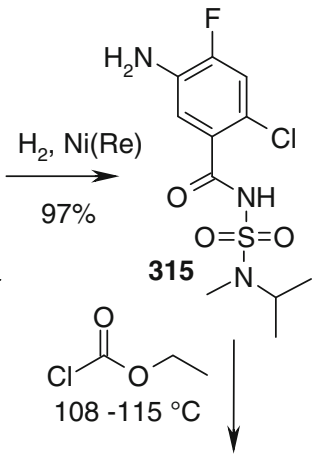<smiles>C=C(NC=CCBr)C(F)(F)F</smiles><smiles>[Y][Y]([Y])=[V]</smiles>
$\mathrm{Me}_{2} \mathrm{SO}_{4}$
$\mathrm{TBAB}, \mathrm{NaOH}$
THF $-\mathrm{H}_{2} \mathrm{O}, 84 \%$<smiles>CC(C)N(C)S(=O)(=O)NC(=O)c1cc(-n2c(=O)cc(C(F)(F)F)n(C)c2=O)c(F)cc1Cl</smiles><smiles>CCOC(=O)Nc1cc(C(=O)NS(=O)(=O)N(C)C(C)C)c(Cl)cc1F</smiles>

Scheme 69 Synthesis of Saflufenacil (294)

In the preparation of Flufenpyr-ethyl (295), hydrazones 318 or 319 were the key synthetic intermediates (Scheme 70) [269-271]. Both compounds 318 and 319 were prepared by reaction of dibromoketone $\mathbf{3 2 0}$ and the corresponding hydrazines 321 and 322, in turn obtained by reduction of diazonium salts $\mathbf{3 2 3}$ and $\mathbf{3 2 4}$. Alternatively, hydrazone 319 was prepared by reaction of $\mathbf{3 2 4}$ and ethyl trifluoroacetoacetate, followed by hydrolysis and decarboxylation.

Further transformations of $\mathbf{3 1 9}$ included reaction with (carbethoxylidene)triphenylphosphorane resulting in the formation of pyridazine derivative 327. Acidic hydrolysis of $\mathbf{3 2 7}$ led to $\mathbf{3 2 8}$, which was alkylated with ethyl bromoacetate to give 295 (Scheme 71). 
<smiles>Nc1cc(O)c(Cl)cc1F</smiles><smiles>[Y]C(C)[N+](=O)[O-]</smiles><smiles></smiles>

323, $\mathrm{R}=\mathrm{H}$

324, $\mathrm{R}=\mathbb{P} \mathrm{Pr}$

321, $\mathrm{R}=\mathrm{H}$

322, $\mathrm{R}=i \mathrm{Pr}$

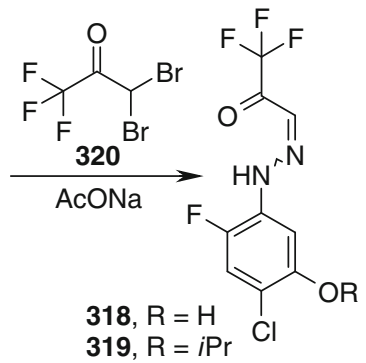<smiles>CCOC(=O)CC(=O)C(F)(F)C(=O)OCC</smiles>

319, $\mathrm{R}=i \mathrm{Pr}$

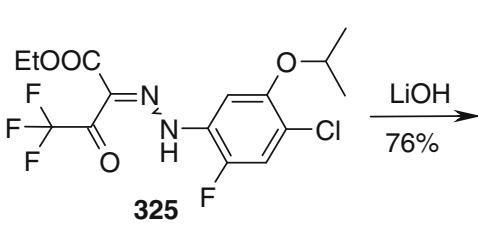<smiles>CC(C)Oc1cc(NN=C(C(=O)O)C(=O)O[Na])c(F)cc1Cl</smiles>

Scheme 70 Syntheses of key intermediates for Flufenpyr-ethyl (295)<smiles>CCOC(=O)COc1cc(-n2ncc(C(F)(F)F)c(C)c2=O)c(F)cc1Cl</smiles>

Scheme 71 Synthesis of Saflufenacil via Wittig approach (295)

Alternatively, either 318 or 319 reacted with methylmalonic acid to give adducts 329 or 330, which underwent cyclization upon heating with carboxylic acid and a base to give $\mathbf{3 3 1}$ and 327, respectively. Both $\mathbf{3 3 1}$ and $\mathbf{3 2 7}$ were transformed to Flufenpyr-ethyl (295) as described above (Scheme 72). 


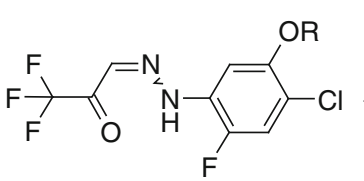

318, $\mathrm{R}=\mathrm{H}$ 319, $\mathrm{R}=i \mathrm{Pr}$
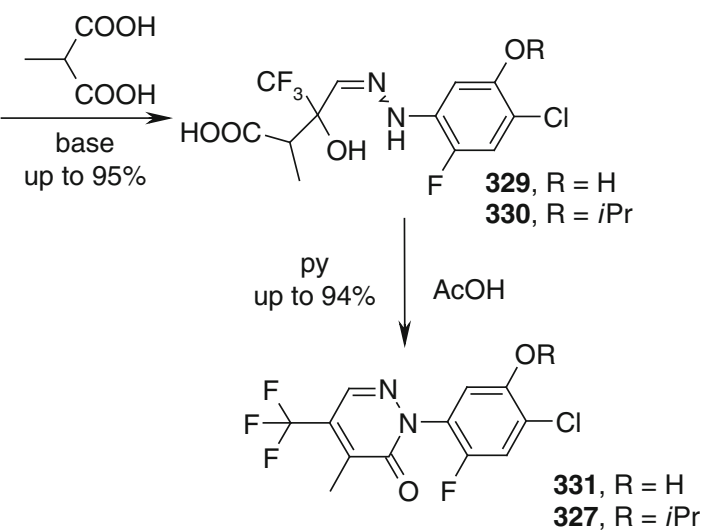

Scheme 72 Synthesis of Saflufenacil via malonate addition (295)

\subsection{Acetohydroxy Acid Synthase Inhibitors}

Compounds discussed in this section are derivatives or analogues of sulfonylurea herbicides - agrochemicals which began the present low-dose era of herbicide chemistry in 1970s [257]. Primisulfuron-methyl (299) (from Ciba-Geigy Corporation and Syngenta AG) is a sulfonylurea derivative introduced in 1990 [262]. It is used for post-emergence control of actively growing weeds in corn and in non-cropland areas [272]. Cloransulam-methyl (296), Florasulam (298), and Diclosulam (297), all developed by Dow AgroSciences, are examples of the triazolopyrimidine sulfonanilide herbicides; they were introduced in 1998, 1999, and 2000, respectively. Cloransulam-methyl is used for soil-applied and post-emergence control of broadleaf weeds in soybeans [273]. Florasulam is a highly-selective broadleaf herbicide which is registered for use in cereals in many countries around the world. Diclosulam-based products are registered for use to control annual and certain perennial broadleaf weeds; they can be can be applied as soil, foliar, or burndown treatments in crops such as sugar cane, peanuts and soybeans and in forestry applications.

Compounds 296-299 inhibit acetohydroxy acid synthase (AHAS), formerly known as acetolactate synthase. Its activity is not present in animals, but it has been found in all plants where measurements have been attempted. Acetohydroxy acid synthase catalyses the first step in production of branched amino acids (leucine, valine and isoleucine) (Scheme 73), which are obviously needed for the protein synthesis and cell growth. The compounds 296-299 seem to bind within the substrate-access channel of the enzyme, thus blocking $\alpha$-ketocarboxylate access to the active site. While these herbicides are undoubtedly highly successful, resistance developed due to mutations within AHAS is becoming a serious problem [274, 275]. 


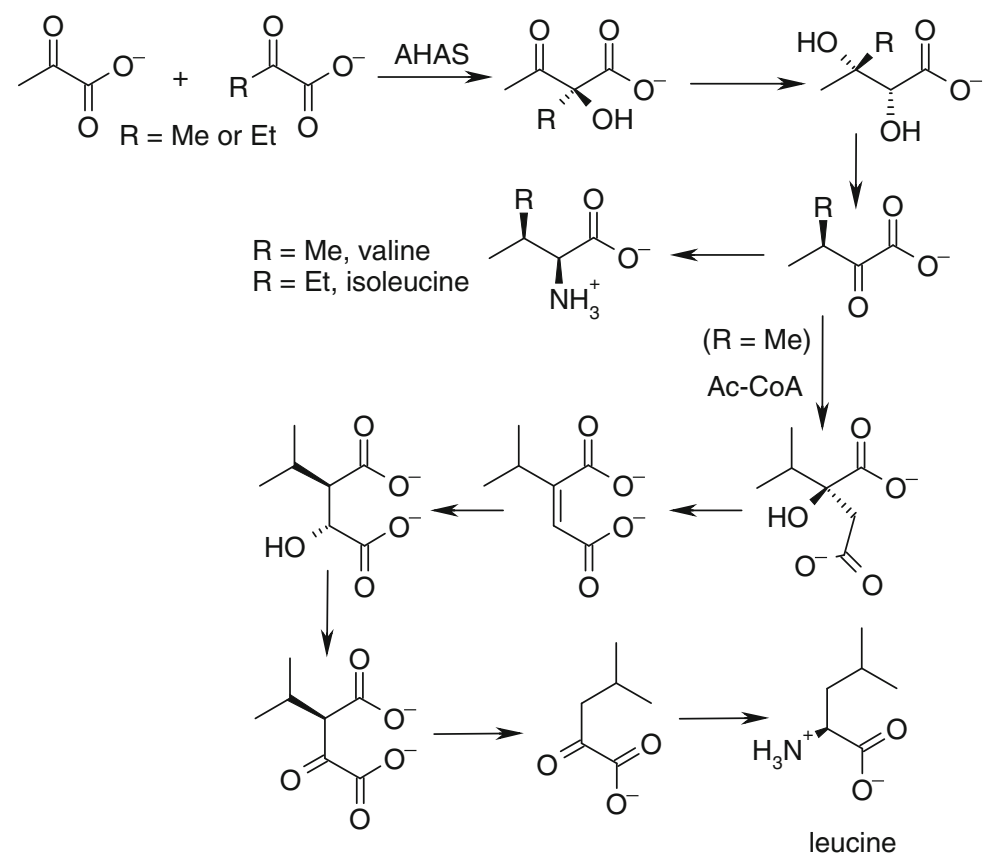

Scheme 73 Biological role of acetohydroxy acid synthase (AHAS)

Primisulfuron-methyl is a slightly toxic for skin, inhalation and eye exposure, with little metabolic activity in mammalian. It is slightly toxic to freshwater fish, aquatic organisms and to marine shrimp and has no toxic effect on birds and honeybees [276]. Cloransulam-methyl can be highly toxic to certain aquatic plants and algae on an acute basis; it is practically nontoxic to other non-plant organisms. Florasulam is highly toxic to aquatic organisms and slightly toxic to birds, and Diclosulam is very highly toxic to aquatic organisms [272].

In contrast to uracile herbecides in which $\mathrm{CF}_{3}$-group is critical for activity in fluorinated triazolopyrimidine series fluorine atom responsible for the methabolitic transformation of the herbecides. The different metabolic pathway of the triazolopyrimidine herbicide diclosulam and Cloransulam-methyl are guided by the fluorine atom at the 7-position on the triazolopyrimidine ring system (Scheme 74). The predominance of one pathway is very crop specific. In cotton, 296 and 297 are metabolized by the displacement of the 7-flouro substituent on the triazolopyrimidine ring by a hydroxy group, forming 332. Its soybean selectivity is attributed to facile conjugation with homo-glutathion (homoGSH), which displaces the 7-fluoro substituent (333). This mechanism was found to only occur in soybeans for these herbecides. In maize and wheat, 296 and 297 are detoxified by hydroxylation at the 4-th position on the aniline moiety (334) followed by subsequent glycosidation [277]. 


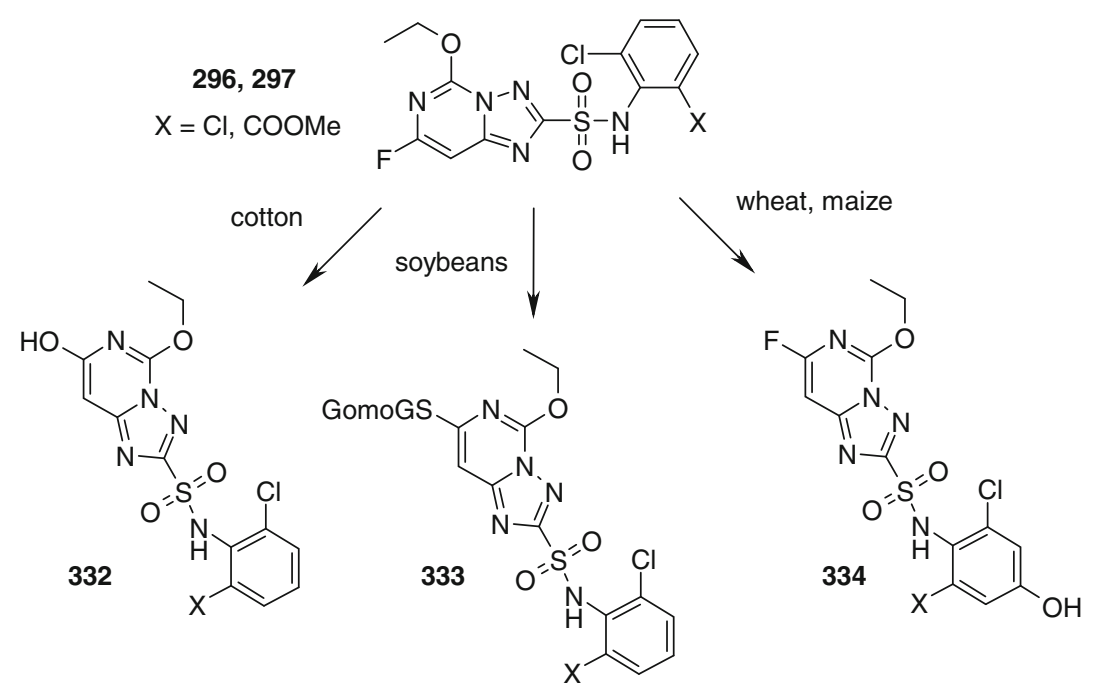

Scheme 74 Metabolism of Cloransulam-methyl (296) and Diclosulam (297) in crops

Cloransulam-methyl (296) and Diclosulam (297) were obtained by reaction of sulfonyl chloride 340 with the corresponding aniline derivatives (Scheme 75). Synthesis of $\mathbf{3 4 0}$ commenced from dichloropyrimidine 335 [278], which reacted with $\mathrm{KF}$ and then - hydrazine hydrate to give 337 . Reaction of 337 with $\mathrm{CS}_{2} / \mathrm{Et}_{3} \mathrm{~N}$ and then - benzyl chloride was accompanied by Dimroth rearrangement and gave

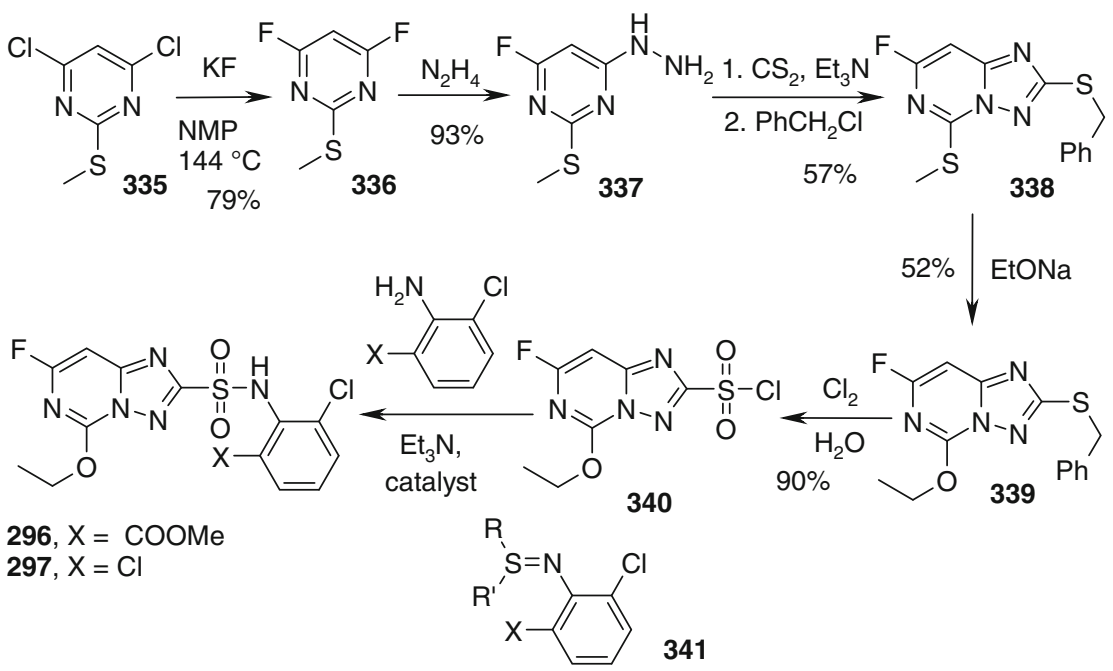

Scheme 75 Synthesis of Cloransulam-methyl (296) and Diclosulam (297) 
$[1,2,4]$ triazolo[1,5-c]pyrimidine derivative $\mathbf{3 3 8}$, which was transformed to $\mathbf{3 3 9}$ by treatment with EtONa. Finally, chlorination of 339 in $\mathrm{H}_{2} \mathrm{O}-\mathrm{CHCl}_{3}$ led to the formation of 340. Reaction of $\mathbf{3 4 0}$ with the corresponding aniline derivatives was performed in the presence of $\mathrm{Me}_{3} \mathrm{SiCl}-\mathrm{NaI}$ [278], as well as of $\mathrm{N}$-arylsulfilimine compounds 341 [279] or 1,2-diols (e.g. 1,2-propanediol) [280].

Florasulam (298) was synthesised starting from dichloropyrimidine 93, which was converted to dimethoxy derivative $\mathbf{3 4 2}$. The reaction of $\mathbf{3 4 2}$ with hydrazine hydrate in $\mathrm{MeOH}$ regioselectively leads to hydrazine 343 , which was cyclized with $\mathrm{CS}_{2}$ into $[1,2,4]$ triazolo[4,3-c]pyrimidine-3-thion $\mathbf{3 4 4}$. The based catalysed Dimroth rearrangement of $\mathbf{3 4 4}$ gave $[1,2,4]$ triazolo[1,5-c]pyrimidine2 -thione 345. Oxidation of $\mathbf{3 4 5}$ followed by chlorination and sulfamide coupling afforded target Florasulam (298) in high preparative yield (Scheme 76) [281-283].

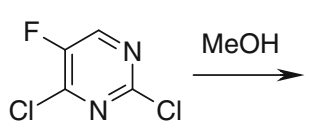

93<smiles>COc1ncc(F)c(NN)n1</smiles>

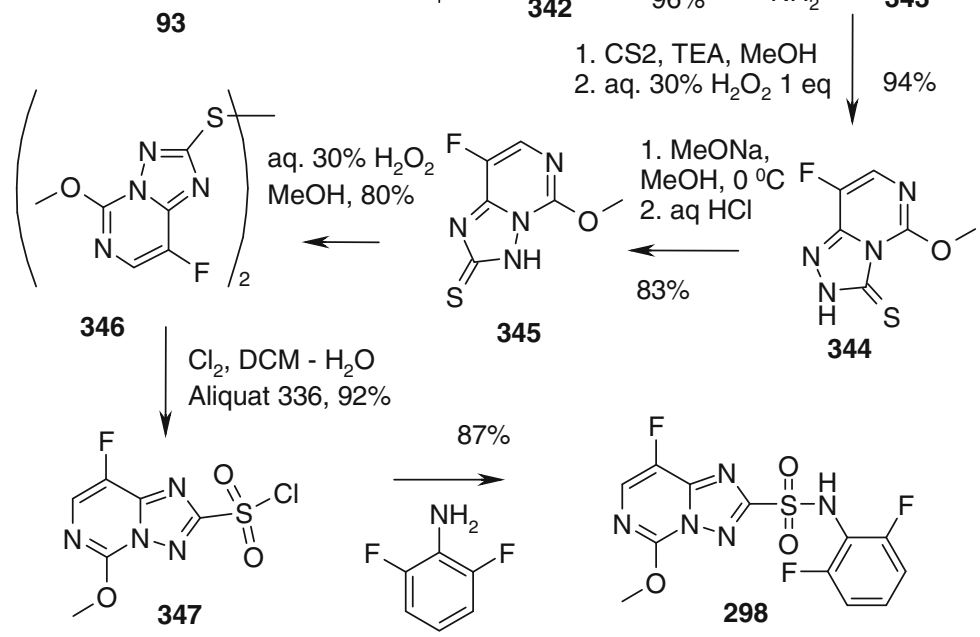

Scheme 76 Synthesis of Florasulam (298)

The synthesis of Primisulfuron-methyl (299) started from reaction of diethyl malonate and thiourea (Scheme 77) [284]. The resulting pyrimidine derivative 348 was methylated, difluoromethylated and then oxidized to give sulfone 351 . Reaction of $\mathbf{3 5 1}$ with aqueous ammonia gave heteroaromatic amine 352, which was transformed to Primisulfuron-methyl (299) upon treatment with isocyanate $\mathbf{3 5 3}$. 


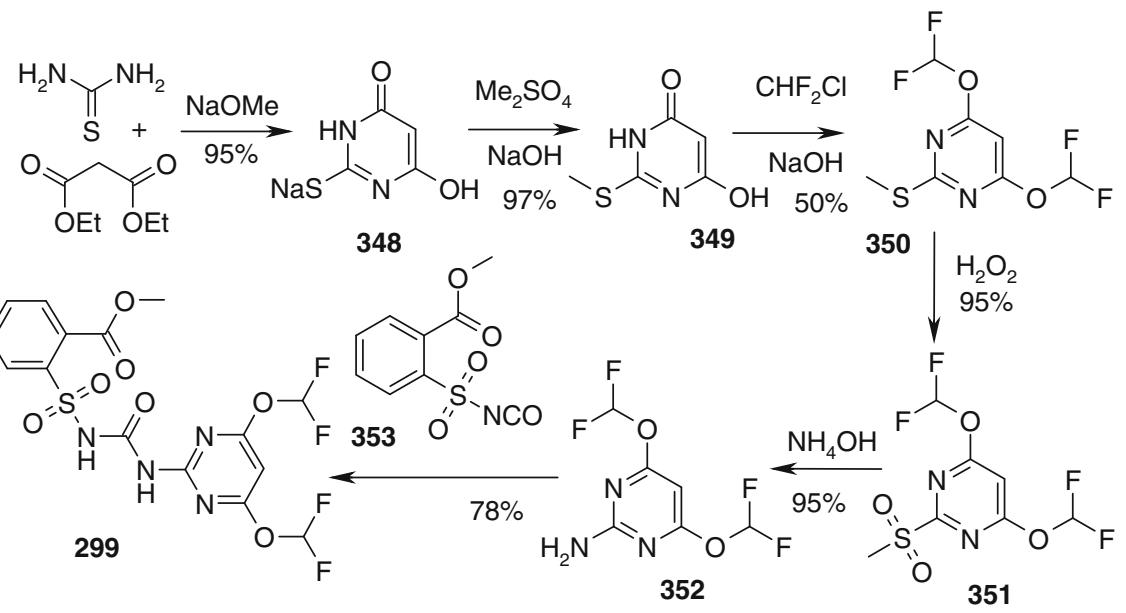

Scheme 77 Synthesis of Primisulfuron-methyl (299)

\section{Mitochondrial Respiratory Chain Inhibitors}

Fluoxastrobin (300) is a pesticide from Bayer CropScience for the control of fungal diseases, which was registered by U. S. environmental protection agency (EPA) in 2005 [276]. Fluoxastrobin is used on peanuts, tuberous and corm vegetables, leaf petiole vegetables, fruiting vegetables and turf. Fluacrypyrim (301) was discovered by BASF AG and introduced in 2002 by Nippon Soda Co., shows acaricidal effect against all stages of tetranychid [285]. Both 299 and $\mathbf{3 0 0}$ are representative of strobilurin family with parent compound Strobilurin A (354) (Fig. 13), discovered in late 1970s [286]. Interestingly, Fluacrypyrim (301) is the first representative of strobilurin family which is not used as a fungicide.

Strobilurins are the part of the larger group of the so-called quinone outside inhibitors (QoI) -compounds which act at the quinol outer binding site of the cytochrome $b c_{l}$ complex. This enzyme, also referred to as ubiquinol: ferricytochrome $c$ reductase, or complex III, is the third complex in the electron transport chain - a cascade of enzymes which couples electron transfer between NADH and $\mathrm{O}_{2}$ with the transfer of $\mathrm{H}^{+}$ions across a membrane to generate chemical energy in the form of adenosine triphosphate (ATP) [287]. The overall result of the reaction catalyzed by cytochrome $b c_{l}$ complex is reduction of ferricytochrome $c$ by oxidation of ubiquinol (355) and the concomitant pumping of 4 protons from the mitochondrial matrix to the intermembrane space. The mechanism of this process is too sophisticated to be discussed herein. It is important that the enzyme has two binding sites for the substrate 355 or its oxidized form 356 (Fig. 14), i.e. outer $\left(Q_{0}\right)$ and inner $\left(\mathrm{Q}_{1}\right)$, and the quinone outside inhibitors bind to the outer site. This leads to inhibition of mitochondrial respiration - a process which is essential to all living organisms. The selective biological effect of quinone outside inhibitors on certain organisms (i.e. fungi or mites) is achieved by differential penetration and 


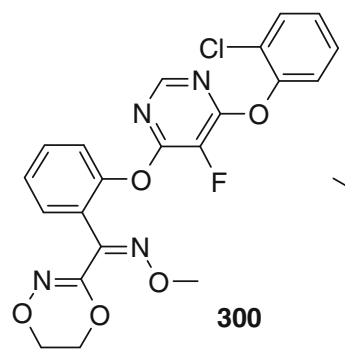<smiles>CO/C=C(/C(=O)OC)c1ccccc1COc1cc(C(F)(F)F)nc(OC(C)C)n1</smiles>

301<smiles>COC=C(C(=O)OC)/C(C)=C\C=C\c1ccccc1</smiles>

Fig. 13 Representatives of strobilurin family

Fig. 14 The structures of ubiquinol (355) and ubiquinone (356)<smiles>COc1c(O)c(C)c(CCC=C(C)C)c(O)c1OC</smiles><smiles>COC1=C(OC)C(=O)C(CCC=C(C)C)=C(C)C1=O</smiles>

degradation between various species, leading to a combination of high fungicidal (or acaricidal, in the case of 301) potency and good crop safety [288]. Unfortunately, resistance has already evolved to this class of pesticides in some plant pathogens in certain geographical areas [289].

Although the in vitro fungicidal activity of the natural strobilurin A was discovered soon, its agrobiological testing in vivo was difficult because of its volatility and the inherent lability of the $(E, Z, E)$-triene system, which resulted in rapid photolytic or metabolic degradation. The unusual structural simplicity of this natural product soon made it a target for chemical derivatization. Below a set of isosterical replacement in a course of lead optimization of natural strobirulin A leading to commercial synthetic products shown on the Fig. 15.

The first sequence leads to first commercialized strobilurin azoxystrobin (1996, Amistar®, Syngenta) and than to fluoxastrobin (300), which structure combines a methoximino 5,6-dihydro-1,4,2-dioxazin-2-yl toxophore (Bayer toxofore) with an optimally adjusted side-chain bearing a 6-(2-chlorophenoxy)-5-fluoro-pyrimidin-4yl-oxy moiety as an essential element. Fluoxastrobin (300) has an advantage as no reorientation of the toxophore is necessary for binding to the target. The SARs studies indicate that the fluorine atom has a beneficial effect on the phytotoxicity and leaf systemicity. Another sequence leads to Picoxystrobin (2002, Acanto®, Syngenta), which has a 6- $\mathrm{CF}_{3}$-pyridin-2-yl moiety in its arylalkyl ether side-chain. An indication switch from the fungicidally to acaricidally active strobilurin type with $\beta$-methoxyacrylate pharmacophore is achieved by exchange of the $6-\mathrm{CF}_{3}-$ pyridin-2-yl moiety in the arylalkyl ether side-chain of Picoxystrobin with a 2-iPrO6- $\mathrm{CF}_{3}$-pyrimidin-4-yl moiety to give fluacrypyrim (301).

Fluoxastrobin (300) was obtained by reaction of compounds 359 and $\mathbf{3 6 0}$ in the presence of $\mathrm{K}_{2} \mathrm{CO}_{3}$ (Scheme 78) [290]. Compound 359 was prepared by reaction of 4,5,6-trifluoropyrimidine (358) with potassium $o$-chlorophenolate. In turn, 358 was obtained from 5-chloro-4,6-difluoropyrimidine (357) by reaction with KF. 


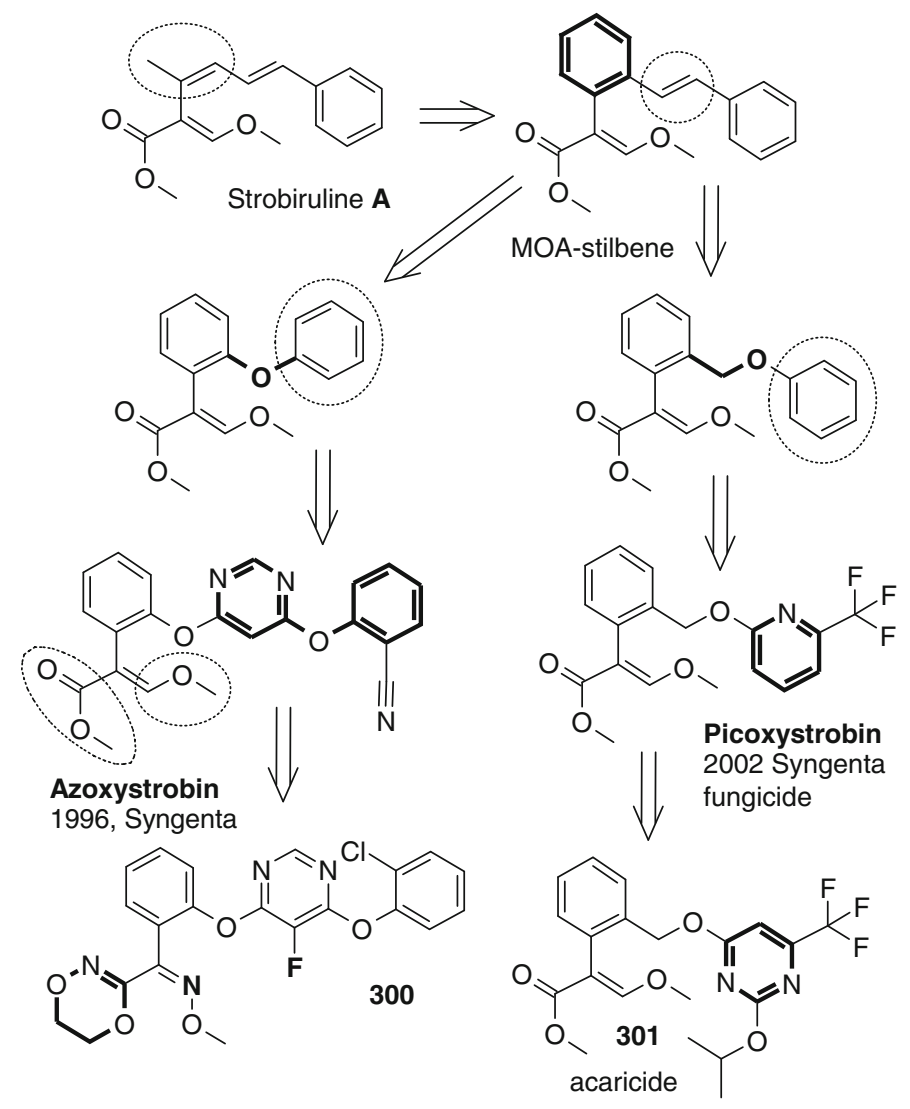

Fig. 15 Map of isosterical replacement for lead optimization of natural strobirulin A

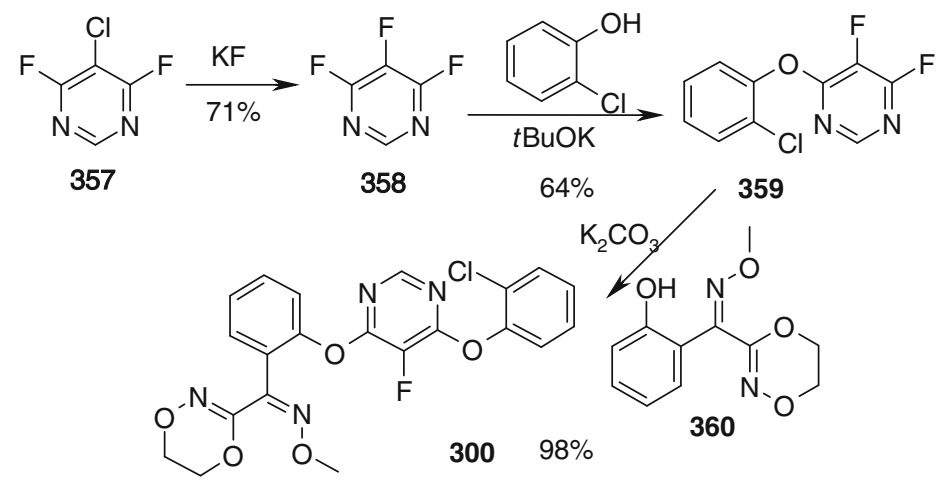

Scheme 78 Synthesis of Fluoxastrobin (300)

The synthesis of key intermediate $\mathbf{3 6 0}$ bearing unusual fragment of 5,6-dihydro-1,4,2-dioxazin was developed by Bayer in 2002. Synthesis started from 
benzofuran-3-one which was converted to oxime $\mathbf{3 6 2}$. Nitrozation of 363 with followed alkylation with bromoethanole leads to bisoxime 364, with under acidic treatment gave target dioxazin $\mathbf{3 6 0}$ (Scheme 79) [291].

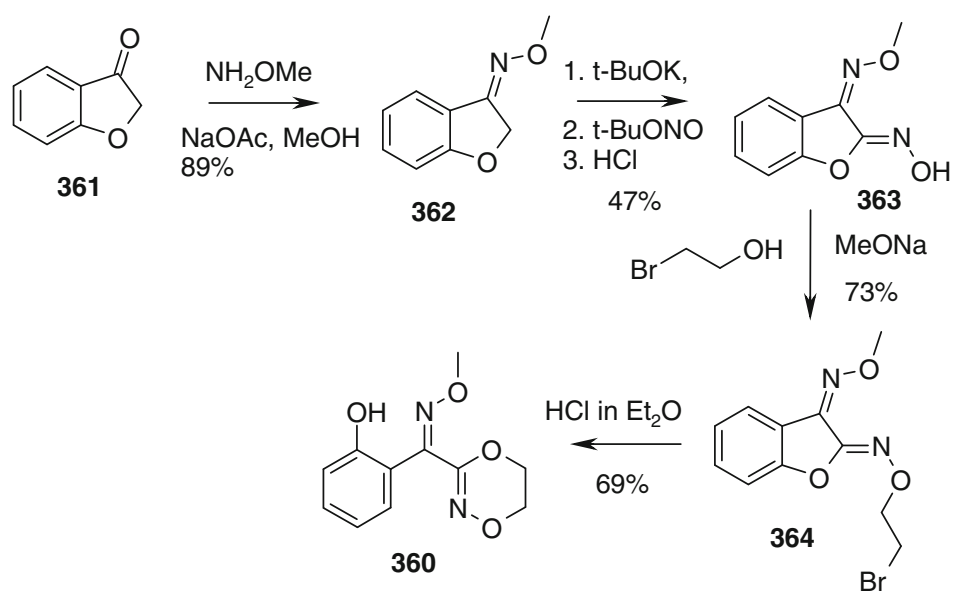

Scheme 79 Synthesis of key intermediate $\mathbf{3 6 0}$

Preparation of Fluacrypyrim (301) started with reaction of $O$-isopropylisourea hydrochloride and ethyl trifluoroacetoacetate to give pyrimidine $\mathbf{3 6 1}$ (Scheme 80) [292]. Alkylation of $\mathbf{3 6 1}$ with bromide $\mathbf{3 6 2}$ (or the corresponding chloride $\mathbf{3 6 3}$ [293,

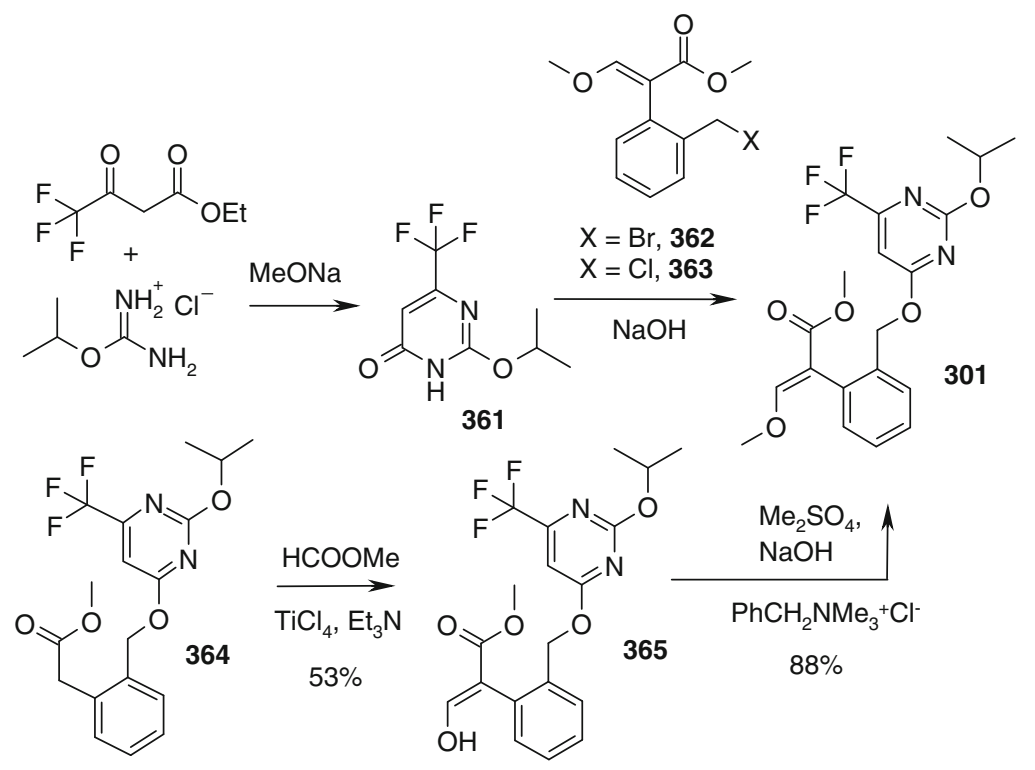

Scheme 80 Syntheses of Fluacrypyrim (301) 
294]) in the presence of alkali or $\mathrm{K}_{2} \mathrm{CO}_{3}$ gave Fluacrypyrim. $\mathrm{Cu}_{2} \mathrm{O}$-catalyzed alkylation of $\mathbf{3 6 1}$ was also developed for the synthesis of $\mathbf{3 0 0}$ [295]. Compounds 362 and $\mathbf{3 6 3}$ were obtained using several closely related methods. In particular, $\mathrm{TiCl}_{4}$-mediated reaction of chloride 366 and methyl orthoformate was used to obtain 363 (Scheme 81) [293, 294]. Alternatively, 366 reacted with methyl formate in the presence of $\mathrm{TiCl}_{4}-$ $\mathrm{Et}_{3} \mathrm{~N}$ to give 367, which was treated with $p$-toluenesulfonic acid in methanol to give 363. Yet another method included reaction of $\mathbf{3 6 7}$ with methyl orthoformate to give 368, which was transformed to $\mathbf{3 6 3}$ upon treatment with methanesulfonic acid.

Another approach to Fluacrypyrim (301) commenced from pyrimidine derivative 364, which reacted with methyl formate in the presence of $\mathrm{TiCl}_{4}-\mathrm{Et}_{3} \mathrm{~N}$ to give $\mathbf{3 6 5}$
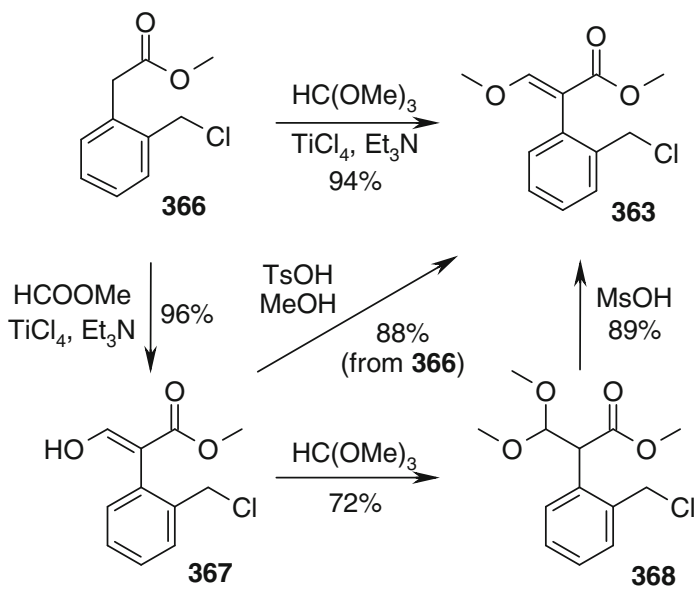

Scheme 81 Synthesis of key intermediate $\mathbf{3 6 3}$

(Scheme 80) [293, 294]. Methylation of $\mathbf{3 6 5}$ using methyl orthoformate or dimethyl sulphate and alkali led to the formation of $\mathbf{3 0 1}$.

The last pesticide from this section is Flufenerim (Flumfen ${ }^{\circledR}$ 302), which is under development by Ube Industries as an insecticide. It is reported to control aphids, whiteflies, and cotton leafworm, but has no activity against thrips [296]. Since Flufenerim is chemically related to Pyrimidifen (Miteclean® 369) (Fig. 16), it was initially believed to have similar mechanism of action, i.e. inhibition of the mitochondrial electron transport of NADH dehydrogenase (NADH: ubiquinone oxidoreductase, complex I) - an enzyme which transfers electrons from NADH to ubiquinone and hence opens the electron transport chain cascade. Nevertheless, it was shown that $\mathbf{3 0 2}$ reduced activity of acetylcholinesterase - an effect which possibly can be addressed to interaction with other systems [297].

Flufenerim (302) was prepared from 4,5-dichloro-6-ethylpyrimidine (347) (Scheme 82) [298]. Compound 370 was chlorinated with chlorine gas; the product 371 thus obtained was subjected to nucleophilic substitution with AcOK to give acetate 372, which upon hydrolysis and subsequent reaction with diethylaminosulphur trifluoride (DAST) gave fluoride 374. Finally, reaction of $\mathbf{3 7 4}$ with amine $\mathbf{3 7 5}$ led to the formation of Flufenerim (302). 
<smiles>CC(F)c1ncnc(NCCc2ccc(OC(F)(F)F)cc2)c1Cl</smiles>

302<smiles>CCOCCc1ccc(OCCNc2ncnc(CC)c2Cl)c(C)c1C</smiles>

Fig. 16 Flufenerim (302) and Pyrimidifen (369)<smiles>CCc1ncnc(Cl)c1Cl</smiles>

370<smiles>CC(Cl)c1ncnc(Cl)c1Cl</smiles>

371<smiles>CC(=O)OC(C)c1ncnc(Cl)c1Cl</smiles>

372<smiles>O=[N+]([O-])CCC(O)c1ncnc(Cl)c1Cl</smiles>

373 DAST<smiles>CC(F)c1ncnc(NCCc2ccc(CC(F)(F)F)cc2)c1Cl</smiles>

Scheme 82 Synthesis of Flufenerim (301)

\section{Conclusions and Outlook}

Since discovery of the first fluorinated diazine - antineoplastic agent 5-fluorouracil more than 20 compounds from the class were introduced into the market. Undoubtedly the success was achieved due to joint progress of medicinal chemistry, agrochemistry as well as synthetic methods of heterocyclic and fluoroorganic chemistry. The continued progresses in these fields of science allow us to predict that the number of fluorine containing diazines as drugs or agrochemicals on the market will be increased. Recent trends in using of perfluorinated diazines as core scaffold for the synthesis of a diverse array of polysubstituted fluorinated diazines for HTS increases probability of these compounds as potential hits and leads. Also the new methodologies of direct introduction of fluorinated substituent, like Baran approach, continue to appear facilitating further investigation. Moreover in the chemical space covered by fluorinated diazines remains "white spots". Thus diazine scaffold decorated by important in med and agrochem fluorinated fragments such as $-\mathrm{CHF}_{2}$, $-\mathrm{CH}_{2} \mathrm{CF}_{3},-\mathrm{OCF}_{3},-\mathrm{SCF}_{3},-\mathrm{SF}_{5}$ not investigated because the synthetic chemistry of these compounds on development phase or not developed at all. Therefore the comprehensive investigations in the field of fluorinated diazines still are interesting both for academic and industrial scientists. 


\section{References}

1. Purser S, Moore PR, Swallow S, Gouverneur V (2008) Fluorine in medicinal chemistry. Chem Soc Rev 37:320-330

2. Filler R, Saha R (2009) Fluorine in medicinal chemistry: a century of progress and a 60-year retrospective of selected highlights. Future Med Chem 1:777-791

3. MDL Drug Data Report (MDDR), Elsevier MDL, version 2012.1. Accessed May 2012

4. Heidelberger C, Chaudhuri NK, Danneberg P, Mooren D, Griesbach L, Duschinsky R, Schnitzer RJ, Pleven E, Scheiner J (1957) Fluorinated pyrimidines, a new class of tumourinhibitory compounds. Nature 179:663-666

5. United States food and drug administration www.fda.gov. Accessed October 2012

6. Rutman RJ, Cantarow A, Paschkis KE (1954) Studies in 2-acetylaminofluorene carcinogenesis. 3. The utilization of uracil-2-C-14 by preneoplastic rat liver and rat hepatoma. Cancer Res 14:119-223

7. Longley DB, Harkin DP, Johnston PG (2003) 5-fluorouracil: mechanisms of action and clinical strategies. Nat Rev Cancer 3:330-338

8. Grem JL (2000) 5-fluorouracil: forty-plus and still ticking. A review of its preclinical and clinical development. Investig New Drugs 18:299-313

9. Avendaño C, Menéndez JC (2008) Medicinal chemistry of anticancer drugs. Elsevier, Amsterdam

10. O'Connor OA (2004) Cancer drug discovery and development: combination cancer therapy: modulators and potentiators. In: Schwartz GK (ed) Combination cancer therapy: modulators and potentiators. Humana Press Inc., Totowa

11. Pinedo HM, Peters GFJ (1988) Fluorouracil: biochemistry and pharmacology. J Clin Oncol 6:1653-1664

12. Carreras CW, Santi DV (1995) The catalytic mechanism and structure of thymidylate synthase. Annu Rev Biochem 64:721-762

13. Heidelberger C, Duschinsky R (1957) 5-Fluorouracil US 2802005

14. Duschinsky R, Pleven E, Heidelberger C (1957) The synthesis of 5-fluoropyrimidines. J Am Chem Soc 79:4559-4560

15. Schuman PD, Tarrant P, Warner DA, Westmoreland G (1976) Process for fluorinating uracil and derivatives thereof. US 3954758

16. Misaki S, Ishii S, Suzuki N, Wakabayashi M, Sowa T (1978) Process for production of 5-fluorouracil and its derivatives. US 4122251

17. Yamazaki A, Morisawa H, Oda Y, Uchida K (1980) Process for producing 5-fluorouracil. US 4186266

18. Hoffer M (1960) Preparation of thymidine and deoxyfluorouridine, and intermediates therefor. US 2949451

19. Von CD, Meinert H (1973) Über die Reaktion von Uracil und seinen Nucleosiden mit elementarem Fluor. J Prakt Chem 315:149-154

20. Visser GWM, Herder RE, Noordhuis P, Zwaagstra O, Herscheid JDM (1988) Reaction of acetyl hypofluorite with pyrimidines. Part 3. Synthesis, stereochemistry, and properties of 5-fluoro-5,6-dihydropyrimidine nucleosides. J Chem Soc Perkin Trans 1:2547-2554

21. Robins MJ, MacCoss M, Naik SR, Ramanis G (1976) Nucleic acid related compounds. 21. Direct fluorination of uracil and cytosine bases and nucleosides using trifluoromethyl hypofluorite. Mechanism, stereochemistry, and synthetic applications. J Am Chem Soc 98:7381

22. Robins MJ, Naik SR (1971) Nucleic acid related compounds. III. Facile synthesis of 5-fluorouracil bases and nucleosides by direct fluorination. J Am Chem Soc 92:5277-5278

23. Chu E (2007) Clinical colorectal cancer: ode to 5-fluorouracil. Clin Colorectal Cancer 6:609-616

24. Álvarez P, Marchal JA, Boulaiz H, Carrillo E, Vélez C, Rodríguez-Serrano F, Melguizo C, Prados J, Madeddu R, Aranega A (2012) 5-fluorouracil derivatives: a patent review. Expert Opin Ther Pat 22:107-123 
25. Giller S, Lidak M, Zhuk R (1967) Verfahren zur Herstellung von N1-(2'Tetrahydrofuryl)undN1-(2'Tetrahydropyranyl)-Derivaten 5-substituierter Urazile und derenAlkalimetallsalzen USSR 2218

26. Giller SA, Zhuk R, Lidak MY, Zidermane AA (1972) N1-(2'-furanidyl)-derivatives of 5-substituted uracils. US 3635946

27. Komastsu T, Yamazaki H, Shimada N (2000) Involvement of microsomal cytochrome P450 and cytosolic thymidine phosphorylase in 5-fluorouracil formation from tegafur in human liver. Drug Metab Dispos 28:1457-1463

28. Yamamiya I, Yoshisue K, Matsushima E, Nagayama S (2010) Formation pathways of $\gamma$-butyrolactone from the furan ring of tegafur during its conversion to 5-fluorouracil. Drug Metab Dispos 38:1267-1276

29. Chugai Pharmaceutical Co. official site http://www.chugai-pharm.co.jp. Accessed 12 Nov 2012

30. Imamura I, Yabumoto M, Fukui H, Wada H, Takechi T, Takeda S, Yamada Y (1993) Comparison of gastrointestinal toxicity of 5-FU derivatives. Jpn J Cancer Chemother 20:1231-1236

31. Mok TSK, Leung TWT, Brown G, Moyses C, Chan ATC, Yeo W, Wong H, Chak K, Johnson P (2004) A phase I safety and pharmacokinetic study of OGT 719 in patients with liver cancerю. Acta Oncol 43:245-251

32. Rohlff C, Watson SA, Morris TM, Skelton L, Jackman AL, Page MJ (1999) A novel, orally administered nucleoside analogue, OGT 719, inhibits the liver invasive growth of a human colorectal tumor, C170HM2. Cancer Res 59:1268-1272

33. Nakajima Y, Iigo M, Hoshi A (1992) Antitumor effect and tumor level of 5-fluoro-2'deoxyuridylate following oral administration of tetradecyl 2'-deoxy-5-fluoro-5'-uridylate. Anticancer Drugs 3:289-292

34. Kuroki Y, Yamashita I, Okamoto M, Ochiai H, Kurokawa M, Tazawa K, Fujimaki M (1991) Antitumor activity of T-506, a novel synthetic FUDR derivative, on murine colon cancer and its hepatic metastasis. Jpn J Cancer Chemother 18:1297-1302

35. Ozaki S (1996) Synthesis and antitumor activity of 5-fluorouracil derivatives. Med Res Rev 16:51-86

36. Maehara Y, Kusumoto H, Anai H, Kusumoto T, Hiramoto Y, Sugimachi K (1987) Sensitivity to six antitumor drugs differs between primary and metastatic liver cancers. Eur J Cancer Clin Oncol 23:1511-1513

37. Kobari T, Iguro Y, Ujiie A, Namekawa H (1981) Metabolism of 1-hexylcarbamoyl-5fluorouracil (HCFU), a new antitumour agent, in rats, rabbits and dogs. Xenobiotica 11:57-62

38. Takenaka K, Kanematsu T, Shimada M, Sugimachi K (1989) Low dose 1-hyxylcarbamoyl-5fluorouracil (HCFU) recommended for cirrhotic patients with hepatocellular carcinoma. Eur J Cancer Clin Oncol 25:1191-1192

39. Li Q, Feng FY, Han J, Sui GJ, Zhu YG, Zhang Y, Zhang ZH, Li L, Wang PH, Zhou MZ, Zhang YC (2002) Phase III clinical study of a new anticancer drug atofluding. Ai Zheng 21:1350-1353

40. Xu W, Zhang Z, Castaner J (2001) Atofluding. Oncolytic. Drugs Future 26:935-938

41. Zhang X, Zhong JL, Liu W, Gao Z, Xue X, Yue P, Wang L, Zhao C, Xu W, Qu X (2010) N(3)o-toluyl-fluorouracil inhibits human hepatocellular carcinoma cell growth via sustained release of 5-FU. Cancer Chemother Pharmacol 66:5836-5846

42. Sugimachi K, Maehara Y (2000) A phase II trial of a new 5-fluorouracil derivative, BOF-A2 (Emitefur), for patients with advanced gastric cancer. Surg Today 30:1067-1072

43. Nakai Y, Furuse K, Ohta M, Yamaguchi Y, Fujii M, Asakawa M, Fukuoka M, Yoshida K, Niitani H (1994) Efficacy of a new 5-fluorouracil derivative, BOF-A2, in advanced non-small cell lung cancer. A multi-center phase II study. Acta Oncol 33:523-526

44. Nemunaitis J, Eager R, Twaddell T, Corey A, Sekar K, Tkaczuk K, Thompson J, Hoff PM, Pazdur RJ (2000) Phase I assessment of the pharmacokinetics, metabolism, and safety of emitefur in patients with refractory solid tumors. Clin Oncol 18:3423-3434 
45. LoRusso PM, Prakash S, Wozniak A, Flaherty L, Zalupski M, Shields A, Sands H, Parchment R, Jasti B (2002) Phase I clinical trial of 5-fluoro-pyrimidinone (5FP), an oral prodrug of 5-fluorouracil (5FU). Investig New Drugs 20:63-71

46. Guo X, Lerner-Tung M, Chen HX, Chang CN, Zhu JL, Chang CP, Pizzorno G, Lin TS, Cheng YC (1995) 5-fluoro-2-pyrimidinone, a liver aldehyde oxidase-activated prodrug of 5-fluorouracil. Biochem Pharmacol 49:1111-1116

47. Ishitsuka H, Smimma N (2008) Capecitabine preclinical studies: from discovery to translational research. In: Herdewijn P (ed) Modified nucleosides in biochemistry biotechnology and medicine. Wiley $\mathrm{VCH}$, Weinheim, pp 585-600

48. Desmoulin F, Gilard V, Malet-Martino M, Martino R (2002) Metabolism of capecitabine, an oral fluorouracil prodrug: ${ }^{19} \mathrm{~F}$ NMR studies in animal models and human urine. Drug Metab Dispos 30:1221-1229

49. Nakamura T, Hoshide Y, Hashimoto Y, Suzuki K, Yoshida Y (1978) Process for producing 5-fluorouracil derivative with a calcium chloride catalyst. US 4121037

50. Kojima A, Kohno Y, Ike Y, Yokoyama T, Odate M (1981) Process for the preparation of 1-(2-tetrahydrofuryl)-5-fluorouracil. US 4256885

51. Ishibashi K, Ishiguro S, Komaki R (1979) Method for the preparation of derivatives of uracil. US 4159378

52. Schonberger E, Sasson Z, Michael U (1979) Process for the preparation of N.sup.1-(2'furanidyl)-5-fluoro-uracil. US 4174446

53. Nomura H, Yoshioka Y, Minami I (1979) Synthesis of tetrahydro-2-furyl derivatives of 5-substituted uracils. Chem Pharm Bull 27:899-906

54. Lukevits E, Trushule M, Zarinya D, Ignatovich LM, Liepin'sh E (1981) Nitrogen-containing organosilicon compounds C. Reaction of 5-fluoro-2,4-bis-O-(Trimethylsilyl)uracil with 2,3-dihydrofuran. J Gen Chem USSR (Engl Transl) 51:827-834

55. Giller SA, Zhuk RA, Likak MY (1967) Analogs of pyrimidine nucleosides I. N,(atetrahydrofuryl) derivatives of natural pyrimidine bases and their antimetabolites. Dokl Chem 176:798-801

56. Earl RA, Townsend LB (1972) The synthesis of 1 (tetrahydro-2-furanyl)-5-fluorouracil (ftorafur) via direct fluorination. J Heterocycl Chem 9:1141-1143

57. Kametani T, Kigasawa K, Hiiragi M, Wakisaka K, Kusama O, Kawasaki K, Sugi H (1977) Synthetic studies on chemotherapeutics. II. Synthesis of phenyl-substituted 1,4-dihydro-4oxonicotinic acid derivatives. [Studies on the syntheses of heterocyclic compounds. Part 704. J Heterocycl Chem 14:473-482

58. Zhuk RA, Berzinya AÉ, Sherin' LA, Kaulinya LT, Giller SA (1977) Analogs of pyrimidine nucleosides. Chem Heterocycl Compd 13:1015-1016

59. Lee CH, Kim JY, Kim WJ, Kim YH (1990) Facile synthesis of tetrahydro-2-furylated pyrimidines and purines using a new catalyst of cesium chloride. Heterocycles 31:211-214

60. Iwasaki T, Nishitani T, Horikawa H, Inoue I (1981) A novel synthesis of 5-fluorouracil derivatives having oxacycloalkane moieties. Tetrahedron Lett 22:1029-1032

61. Townsend LB, Earl RA (1976) Synthesis of 1-(tetrahydro-2-furanyl)-5-fluorouracil (Ftorafur) via direct fluorination. US 3948897

62. Miyashita O, Matsumura K, Shimadzu H, Hashimoto N (1981) Studies on fluorinated pyrimidines. I. A new method of synthesizing 5-fluorouracil and its derivatives. Chem Pharm Bull 29:3181-3190

63. Hřebabecký H, Beránek J (1978) 5'-halogeno-2',3'-cyclic sulphite isomers in the preparation of 5'-halogeno nucleosides. Synthesis of 5'-deoxyuridine and 5'-deoxy-5-fluorouridine. Nucleic Acids Res 5:1029-1040

64. Hřebabecký H, Beránek J (1978) 5'-halogeno-2',3'-sulphites in the synthesis of 2',5'-dideoxy5-fluorouridine and related analogues. Collect Czechoslov Chem Commun 43:3268-3278

65. Cook AF, Holman MJ, Kramer MJ, Trown PW (1979) Fluorinated pyrimidine nucleosides. 3. Synthesis and antitumor activity of a series of 5'-deoxy-5-fluoropyrimidine nucleosides. J Med Chem 22:1330-1335 
66. D'Souza R, Kiss J (1982) 5'-deoxy-5-fluorouridine. US 4340729

67. Kiss J, D'Souza R, Koeveringe JA, van Arnold W (1982) 149. stereospezifische synthese des cancerostatikums 5'-desoxy-5-fluor-uridin (5-DFUR) und seiner 5'-deuterierten derivate. Helv Chim Acta 65:1522-1537

68. Shen B, Jamison TF (2012) Rapid continuous synthesis of 5-deoxyribonucleosides in flow via Brønsted acid catalyzed glycosylation. Org Lett 14:3348-3351

69. Schwarz B, Cech D, Holy A, Skoda J (1980) Preparation, antibacterial effects and enzymatic degradation of 5-fluorouracil nucleosides. Collect Czechoslov Chem Commun 45:3217-3230

70. Visser GWM, Herder RE, Noordhuis P, Zwaagstra O, Herscheid JDM, Kanter FJJ (1988) Reaction of acetylhypofluorite with pyrimidines. Part 3. Synthesis, stereochemistry and properties of 5-fluor-5,6-dihydropyrimidine-nucleosides. J Chem Soc Perkin Trans 1:2547-2554

71. Hoffman-La Roche and Co (1965) GB 080491 Chem Abstr. 1968, 68, 96109v

72. Bukhman VM, Brusentsov NA, Kikot' BS, Volodin YY, Chertkova AI, Preobrazhenskaya MN (1981) Synthesis and antitumor activity of phagocytic conjugates of 5-fluorouracil with albumin. Pharm Chem J 15:575-580

73. Haeckel R, Weber K, Germann C, Haberkorn U, Zeisler S, Eisenbarth J, Wiessler M, Oberdorfer F (1996) Synthesis of F-18 labeled nucleoside analogues. J Label Compd Radiopharm 38:1061-1070

74. Courtney SM (1999) Therapeutic compounds with pyrimidine base. US 5945406

75. Watanabe K, Saito M, Kato Y, Oba T, Fukushima H, Hara T (1983) 5-fluoro-2'-deoxyuridine derivatives and a process for the preparation thereof. EP $0081386 \mathrm{~A} 1$

76. Takako H, Isao M, Shinji M (1987) Novel 5-fluoro-2-deoxyuridine derivatives and salts thereof, process for producing the same, and antitumor agents containing the same. US 4684631

77. Ozaki S, Ike Y, Mizuno H, Ishikawa K, Mori H (1977) 5-fluorouracil derivatives. I. The synthesis of 1-carbamoyl-5-fluorouracils. Bull Chem Soc Jpn 50:2406-2412

78. Ozaki S, Mori H (1978) 1-carbamoyl-5-fluorouracil derivatives. US 4071519

79. Kametani T, Kigasawa K, Hiiragi M, Wakisaka K, Haga S, Nagamatsu Y, Sugi H, Fukawa K, Irino O, Yamamoto T, Nishimura N, Taguchi A, Okada T, Nakayama M (1980) Studies on the syntheses of heterocyclic compounds. 845. Studies on the synthesis of chemotherapeutics. 10. Synthesis and antitumor activity of $N$-acyl- and $N$-(alkoxycarbonyl)-5-fluorouracil derivatives. J Med Chem 23:1324

80. Hirohashi M, Kido M, Yamamoto Y, Kojima Y, Jitsukawa K, Fujii S (1993) Synthesis of 5-fluorouracil derivatives containing an inhibitor of 5-fluorouracil degradation. Chem Pharm Bull 41:1498

81. Fujii S (1991) 5-fluorouracil derivatives. US 4983609

82. Fujii S (1989) 5-fluorouracil derivatives. US 4864021

83. Beaman AG, Duschinsky R (1967) Derivatives of pyrimidine. US 3317532

84. Undheim K, Gacek M (1969) Some derivatives of 5-fluoropyrimidine. Acta Chem Scand 23:294-299

85. Driscoll JS, Marquez VE, Plowman J, Liu PS, Kelley JA, Barchi JJ (1991) Antitumor properties of $2(1 H)$-pyrimidinone riboside (zebularine) and its fluorinated analogs. J Med Chem 34:3280-3284

86. Budesinsky Z, Prikryl J, Jelinek V (1968) 2-hydroxy-5-fluoropyrimidines. CS122776

87. Reichardt C, Halbritter K (1975) Synthesen mit substituierten Malondialdehyden, XIX. Darstellung fluorsubstituierter Carbo- und Heterocyclen. Lieb Ann Chem 1975:470-483

88. Beerbaum H, Cech D, Holý A (1978) Verfahren zur herstellung von 5-fluorpyrimidin-2-on und seinen $N$-1-substituierten derivaten. DD 128123

89. Cech D, Beerbaum H, Holý A (1977) A simple synthesis of 5-fluoro-2-pyrimidinone and its $\mathrm{N}^{1}$-substituted derivatives. Collect Czechoslov Chem Commun 42:2694-2700 
90. Arasaki M, Ishitsuka H, Kuruma I, Miwa M, Murasaki C, Shimma N, Umeda I (1995) N4-(substituted-oxycarbonyl)-5'-deoxy-5-fluorocytidine compounds, compositions and methods of using same. US 5472949

91. Shimma N, Umeda I, Arasaki M, Murasaki C, Masubuchi K, Kohchi Y, Miwa M, Ura M, Sawada N, Tahara H, Kuruma I, Horiid I, Ishitsuka H (2000) The design and synthesis of a new tumor-selective fluoropyrimidine carbamate, capecitabine. Bioorg Med Chem 8:1697-1706

92. Ettema GJB (2008) Processes related to making capecitabine. US 2008300399

93. MacDonald PL, Rossetto P, Gallina M (2009) Process for the preparation of capecitabine. US 2009209754

94. Estok TM, Zaknoen SL, Mansfield RK, Lawhon T (2009) Combination therapy for the treatment of cancer using cox-2 inhibitors and dual inhibitors of EGFR [ErbB1] and HER-2 [ErbB2]. WO 2009042613

95. Jhansi Rani V, RaghavendraA, Kishore P, Nanda KumarY, Hema Kumar K, Jagadeeswarareddy K (2012) Synthesis and biological activity evaluation of cytidine-5'-deoxy-5-fluoro-N[(alkoxy/aryloxy)] carbonyl-cyclic 2',3'-carbonates. Eur J Med Chem 54:690-696

96. Palle RV, Marathe AM, Aluru S, Bochha R, Kadaboina R, Nariyam SM, Patni A (2008) Process for preparing capecitabine. WO 2008131062

97. Lee J, Park G-S, Yang WK, Kim JH, Park CH, An Y-H, Lee YJ, Chang Y-K, Lee GS (2009) Methods for preparing capecitabine and beta-anomer-rich trialkyl carbonate compound used therein. WO 2009066892

98. Fujiu M, Ishitsuka H, Miwa M, Umeda I, Yokose K (1990) Fluorocytidine derivatives. US 4966891

99. ClinicalTrials.gov: a service of the U.S. National Institutes of Health http://clinicaltrials.gov. Accessed 19 Dec 2012

100. Emura T, Suzuki N, Yamaguchi M, Ohshimo H, Fukushima M (2004) A novel combination antimetabolite, TAS-102, exhibits antitumor activity in FU-resistant human cancer cells through a mechanism involving FTD incorporation in DNA. Int J Oncol 25:571-578

101. Suzuki N, Nakagawa F, Nukatsuka M, Fukushima M (2011) Trifluorothymidine exhibits potent antitumor activity via the induction of DNA double-strand breaks. Exp Ther Med 2:393-397

102. Nakayama C, Wataya Y, Meyer RB, Santi DV (1980) Thymidine phosphorylase. Substrate specificity for 5-substituted 2'-deoxyuridines. J Med Chem 23:962-964

103. Emura T, Suzuki N, Fujioka A, Ohshimo H, Fukushima M (2005) Potentiation of the antitumor activity of $\alpha, \alpha, \alpha$-trifluorothymidine by the co-administration of an inhibitor of thymidine phosphorylase at a suitable molar ratio in vivo. Int J Oncol 27:449-456

104. Takeda S, Yamashita J, Saito H, Uchida J, Satake H, Yamada Y, Unemi N, Wataya Y, Hayatsu H (1991) Antitumor activity of FTC-092, a masked 5-trifluoromethyl-2'-deoxyuridine derivative. Cancer Chemother Pharmacol 29:122-126

105. Heidelberger C, Parsons D, Remy DC (1962) Syntheses of 5-trifluoromethyluracil and 5-trifluoromethyl-2'-deoxyuridine. J Am Chem Soc 84:3597-3598

106. Ryan KJ, Acton EM, Goodman L (1970) Alternative synthesis of 2'-deoxy-5-(trifluoromethyl)uridine and the $\alpha$-anomer thereof. US 3531464

107. Kawakami H, Ebata T, Koseki K, Matsushita H, Naoi Y, Mizutani N (1990) The synthesis of 2'-deoxy-5-trifluoromethyluridine utilizing a coupling reaction. Heterocycles 31:569-574

108. Tanabe Y, Matsuo N, Ohno N (1988) Direct perfluoroalkylation including trifluoromethylation of aromatics with perfluoro carboxylic acids mediated by xenon difluoride. J Org Chem 53:4582-4585

109. Kobayashi Y, Yamamoto K, Asai T, Nakano M, Kumadaki I (1980) Studies on organic fluorine compounds. Part 35. Trifluoromethylation of pyrimidine and purine nucleosides with trifluoromethyl-copper complex. J Chem Soc Perkin Trans 1:2755-2761

110. Yamashita J, Takeda S, Matsumoto H, Unemi N, Yasumoto M (1989) Studies on antitumor agents. 8. Antitumor activities of $O$-alkyl derivatives of $2^{\prime}$-deoxy-5-(trifluoromethyl)uridine and 2'-deoxy-5-fluorouridine. J Med Chem 32:136-139 
111. Yamashita J, Matsumoto H, Kobayashi K, Noguchi K, Yasumoto M, Ueda T (1989) Studies on antitumor agents. IX. Synthesis of 3'-O-benzyl-2'-deoxy-5-trifluoromethyluridine. Chem Pharm Bull 37:2287-2292

112. Ollmann JE, Depasquale RJ (1990) 2-deoxyuridines and riboside precursors. US 4898936

113. ClinicalTrials.gov: a service of the U.S. National Institutes of Health http://clinicaltrials.gov. Accessed Jan 2013

114. Sanchez Martinez C, Gelbert LM, Shannon H, de Dios A, Staton BA, Ajamie RT, Sawada G, Wishart GN, Raub TJ (2011) Abstract B234: LY2835219, a potent oral inhibitor of the cyclindependent kinases 4 and 6 (CDK4/6) that crosses the blood-brain barrier and demonstrates in vivo activity against intracranial human brain tumor xenografts. Mol Cancer Ther 10:B234

115. Shapiro GI (2006) Cyclin-dependent kinase pathways as targets for cancer treatment. J Clin Oncol 24:1770-1783

116. Sweeny DJ, Li W, Clough J, Bhamidipati S, Singh R, Park G, Baluom M, Grossbard E, Lau DT (2010) Metabolism of fostamatinib, the oral methylene phosphate prodrug of the spleen tyrosine kinase inhibitor R406 in humans: contribution of hepatic and gut bacterial processes to the overall biotransformation. Drug Metab Dispos 38:1166-1176

117. Robak T, Robak E (2012) Tyrosine kinase inhibitors as potential drugs for B-cell lymphoid malignancies and autoimmune disorders. Expert Opin Investig Drugs 21:921-947

118. McLaughlin J, Markovtsov V, Li H, Wong S, Gelman M, Zhu Y, Franci C, Lang D, Pali E, Lasaga J, Low C, Zhao F, Chang B, Gururaja TL, Xu W, Baluom M, Sweeny D, Carroll D, Sran A, Thota S, Parmer M, Romane A, Clemens G, Grossbard E, Qu K, Jenkins Y, Kinoshita T, Taylor V, Holland SJ, Argade A, Singh R, Pine P, Payan DG, Hitoshi Y (2010) Preclinical characterization of Aurora kinase inhibitor R763/AS703569 identified through an imagebased phenotypic screen. J Cancer Res Clin Oncol 136:99-113

119. Schöffski P, Jones SF, Dumez H, Infante JR, Van Mieghem E, Fowst C, Gerletti P, Xu H, Jakubczak JL, English PA, Pierce KJ, Burris HA (2011) Phase I, open-label, multicentre, dose-escalation, pharmacokinetic and pharmacodynamic trial of the oral aurora kinase inhibitor PF-03814735 in advanced solid tumours. Eur J Cancer 47:2256-2264

120. Jani JP, Arcari J, Bernardo V, Bhattacharya SK, Briere D, Cohen BD, Coleman K, Christensen JG, Emerson EO, Jakowski A, Hook K, Los G, Moyer JD, Pruimboom-Brees I, Pustilnik L, Rossi AM, Steyn SJ, Su C, Tsaparikos K, Wishka D, Yoon K, Jakubczak JL (2010) PF-03814735, an orally bioavailable small molecule aurora kinase inhibitor for cancer therapy. Mol Cancer Ther 9:883-894

121. Hedvat M, Huszar D, Herrmann A, Gozgit JM, Schroeder A, Sheehy A, Buettner R, Proia D, Kowolik CM, Xin H, Armstrong B, Bebernitz G, Weng S, Wang L, Ye M, McEachern K, Chen H, Morosini D, Bell K, Alimzhanov M, Ioannidis S, McCoon P, Cao ZA, Yu H, Jove R, Zinda M (2009) The JAK2 inhibitor AZD1480 potently blocks Stat3 signaling and oncogenesis in solid tumors. Cancer Cell 16:487-497

122. Ioannidis S, Lamb ML, Wang T, Almeida L, Block MH, Davies AM, Peng B, Su M, Zhang HJ, Hoffmann E, Rivard C, Green I, Howard T, Pollard H, Read J, Alimzhanov M, Bebernitz G, Bell K, Ye M, Huszar D, Zinda M (2011) Discovery of 5-chloro-N2-[(1S)-1-(5fluoropyrimidin-2-yl)ethyl]- $N 4$-(5-methyl-1 $H$-pyrazol-3-yl)pyrimidine-2,4-diamine (AZD1480) as a novel inhibitor of the Jak/Stat pathway. J Med Chem 54:262-276

123. Coates DA, Gelbert L, Knobeloch JM, De Dioz Magana A, de Prado Gonzalez A, Filadelfa del Prado Catalina M, Garcia Paredes M, Martin de la Nava EM, Martin Ortega Finger M, Martinez Perez JA, Mateo Herranz AI, Perez Martinez C, Sanchez Martinez C (2010) Protein kinase inhibitors. US 2010160340

124. Rajinder S, Ankush A, Li H, Bhamidipati S, Carroll D, Sylvain C, Clough J, Keim H (2005) Pyrimidinediamine compounds for use in the treatment or prevention of autoimmune diseases. WO 2005012294

125. Felfer U, Giselbrecht K-H, Wolberg M (2011) Synthesis of 2,4-pyrimidinediamines. US 2011003986

126. Li H, Argade A, Singh R, Thota S, Carroll D, Tso K, Taylor V, Mclaughlin J, Markovstov V (2005) Cycloalkyl substituted pyrimidinediamine compounds and their uses. WO 2005118544 
127. Feng X, Guan H, Kan Y, Ioannidis S, Peng B, Su M, Wang B, Wang T, Zhang H-J (2007) 4-(3-Aminopyrazole)pyrimidine derivatives for use as tyrosine kinase inhibitors in the treatment of cancer. WO 2007049041

128. De Clercq E (2009) Anti-HIV drugs: 25 compounds approved within 25 years after the discovery of HIV. Int J Antimicrob Agents 33:307-320

129. Saag MS (2006) Emtricitabine, a new antiretroviral agent with activity against HIV and hepatitis B virus. Clin Infect Dis 42:126-131

130. Mirochnick M, Capparelli E (2004) Pharmacokinetics of antiretrovirals in pregnant women. Clin Pharmacokinet 43:1071-1087

131. Wilson JE, Martin JL, Borroto-Esoda K, Hopkins S, Painter G, Liotta DC, Furman PA (1993) The 5'-triphosphates of the (-) and (+) enantiomers of cis-5-fluoro-1-[2-(hydroxymethyl)1,3-oxathiolane-5-yl]cytosine equally inhibit human immunodeficiency virus type 1 reverse transcriptase. Antimicrob Agents Chemother 37:1720-1722

132. Furman PA, Davis M, Liotta DC, Paff M, Frick LW, Nelson DJ, Dornsife R, Wurster JA, Wilson JJ, Fyfe JA, Tuttle JV, Condreay L, Averett D, Schinazi R, Painter G (1992) The antihepatitis B virus activities, cytotoxicities, and anabolic profiles of the (-) and (+) enantiomers of cis-5-fluoro-1-[2-(hydroxymethyl)-1,3-oxathiolan-5-yl]cytosine. Antimicrob Agents Chemother 36:2686-2692

133. Otto MJ (2004) New nucleoside reverse transcriptase inhibitors for the treatment of HIV infections. Curr Opin Pharmacol 4:431-436

134. Achillion Pharmaceuticals official site http://www.achillioncom/elvucitabine_program_ overview. Accessed 5 Jan 2013

135. Hoffmann C (2011) Overview of antiretroviral agents. In: Hoffmann C, Rockstroh JK (eds) HIV book 2011. Medizin Fokus Verlag, Hamburg, pp 64-109

136. Corbett JW, Ko SS, Rodgers JD, Jeffrey S, Bacheler LT, Klabe RM, Diamond S, Lai CM, Rabel SR, Saye JA, Adams SP, Trainor GL, Anderson PS, Erickson-Viitanen SK (1999) Expanded-spectrum nonnucleoside reverse transcriptase inhibitors inhibit clinically relevant mutant variants of human immunodeficiency virus type 1. Antimicrob Agents Chemother 43:2893-2897

137. Corbett JW, Ko SS, Rodgers JD, Gearhart LA, Magnus NA, Bacheler LT, Diamond S, Jeffrey S, Klabe RM, Cordova BC, Garber S, Logue K, Trainor GL, Anderson PS, Erickson-Viitanen SK (2000) Inhibition of clinically relevant mutant variants of HIV-1 by quinazolinone nonnucleoside reverse transcriptase inhibitors. J Med Chem 43:2019-2030

138. Ren J, Milton J, Weaver KL, Short SA, Stuart DI, Stammers DK (2000) Structural basis for the resilience of efavirenz (DMP-266) to drug resistance mutations in HIV-1 reverse transcriptase. Structure 8:1089-1094

139. Mutlib A, Chen H, Shockcor J, Espina R, Chen S, Cao K, Du A, Nemeth G, Prakash S, Gan LS (2000) Characterization of novel glutathione adducts of a non-nucleoside reverse transcriptase inhibitor, (S)-6-chloro-4-(cyclopropylethynyl)-4-(trifluoromethyl)-3,4-dihydro2(1H)-quinazolinone (DPC 961), in rats. Possible formation of an oxirene metabolic intermediate from a disubstituted alkyne. Chem Res Toxicol 13:775-784

140. Jeong LS, Schinazi RF, Beach JW, Kim HO, Nampalli S, Shanmuganathan K, Alves AJ, McMillan A, Chu CK, Mathis R (1993) Asymmetric synthesis and biological evaluation of $\beta$-L-(2R,5S)- and $\alpha-\mathrm{L}-(2 R, 5 R)-1,3$-oxathiolane-pyrimidine and -purine nucleosides as potential anti-HIV agents. J Med Chem 36:181-195

141. Jeong LS, Schinazi RF, Beach JW, Kim HO, Shanmuganathan K, Nampalli S, Chun MW, Chung WK, Choi BG, Chu CK (1993) Structure-activity relationships of $\beta$-D-(2S,5R)and $\alpha$-D-(2S,5S)-1,3-oxathiolanyl nucleosides as potential anti-HIV agents. J Med Chem 36:2627

142. Liotta DC, Schinazi RF, Choi W-B (1997) Method for the synthesis, compositions and use of 2'-deoxy-5-fluoro-3'-thiacytidine and related compounds. US 5700937

143. Liotta DC, Schinazi RF, Choi W-B (2002) Intermediates in the synthesis of 1,3-oxathiolane nucleoside enantiomers. US 6346627 
144. Mansour T, Jin H, Tse AHL, Siddiqui MA (1997) Processes for the diastereoselective synthesis of nucleoside analogues. US 5696254

145. Kshirsagar PB, Bhoge SM, Richhariya S, Singh K (2011) Novel process for the preparation of $c i s$-nucleoside derivative. WO 2011107920

146. Samano MC, Samano V (2000) 4-ethoxy-pyrimidines. US 6066733

147. Lin TS, Luo MZ, Liu MC, Zhu YL, Gullen E, Dutschman GE, Cheng YC (1996) Design and synthesis of $2^{\prime}, 3^{\prime}$-dideoxy-2', $3^{\prime}$-didehydro-beta-L-cytidine (beta-L-d4C) and 2',3'-dideoxy $2^{\prime}, 3^{\prime}$-didehydro-beta-L-5-fluorocytidine (beta-L-Fd4C), two exceptionally potent inhibitors of human hepatitis B virus (HBV) and potent inhibitors of human immunodeficiency virus (HIV) in vitro. J Med Chem 39:1757-1759

148. Chen S-H, Li X, Li J, Niu C, Carmichael E, Doyle TW (1997) Stereoselective syntheses of $\beta$-L-FD4C and $\beta$-L-FddC. J Org Chem 62:3449

149. Shi J, McAtee JJ, Wirtz SS, Tharnish P, Juodawlkis A, Liotta DC, Schinazi RF (1999) Synthesis and biological evaluation of $2^{\prime}, 3^{\prime}$-didehydro-2',3'-dideoxy-5-fluorocytidine (D4FC) analogues: discovery of carbocyclic nucleoside triphosphates with potent inhibitory activity against HIV-1 reverse transcriptase. J Med Chem 42:859-867

150. Chen S-H, Lin S, King I, Spinka T, Dutschman GE, Gullen EA, Cheng Y-C, Doyle TW (1998) Synthesis and comparative evaluation of two antiviral agents: $\beta$-L-Fd4C and $\beta-D-$ Fd4C. Bioorg Med Chem Lett 8:3245-3250

151. Kowalczyk B, Zhao L, Schure RM, Dunkle L (2003) Method for synthesizing beta-l-fluoro$2^{\prime}, 3^{\prime}$ didehydcytidine ( $\beta$-L-Fd4C). WO 2003087119

152. Jin F, Confalone PN (2002) Method for the synthesis of $2^{\prime}, 3^{\prime}$-dideoxy-2', $3^{\prime}$ didehydronucleosides. WO 2002070533

153. Choudhury A, Pierce ME, Nguyen D, Storace L, Confalone PN (2005) Synthesis of D-D4FC, a biologically active nucleoside via an unprecedented palladium mediated Ferrier rearrangement-type glycosidation with an aromatization prone xylo-furanoid glycal. Tetrahedron Lett 46:8099-8102

154. Magnus NA, Confalone PN, Storace L (2000) A new asymmetric 1,4-addition method: application to the synthesis of the HIV non-nucleoside reverse transcriptase inhibitor DPC 961. Tetrahedron Lett 41:3015-3019

155. Magnus NA, Confalone PN, Storace L, Patel M, Wood CC, Davis WP, Parsons RL (2003) General scope of 1,4-diastereoselective additions to a $2(3 \mathrm{H})$-quinazolinone: practical preparation of HIV therapeutics. J Org Chem 68:754-761

156. Kauffman GS, Harris GD, Dorow RL, Stone BRP, Parsons RL, Pesti JA, Magnus NA, Fortunak JM, Confalone PN, Nugent WA (2000) An efficient chiral moderator prepared from inexpensive (+)-3-carene: synthesis of the HIV-1 non-nucleoside reverse transcriptase inhibitor DPC 963. Org Lett 2:3119-3121

157. Parsons RL, Fortunak JM, Dorow RL, Harris GD, Kauffman GS, Nugent WA, Winemiller MD, Briggs TF, Xiang B, Collum DBJ (2001) NMR spectroscopic investigations of mixed aggregates underlying highly enantioselective 1,2-additions of lithium cyclopropylacetylide to quinazolinones. Am Chem Soc 123:9135-9143

158. Jiang B, Si Y-G (2004) Highly enantioselective construction of a chiral tertiary carbon center by alkynylation of a cyclic N-acyl ketimine: an efficient preparation of HIV therapeutics. Angew Chem Int Ed 43:216-218

159. Jiang B, Jia JD, Yu GS, Xiao LZ, Zuo GH, Xu M (2008) Highly enantioselective construction of a quaternary carbon center of dihydroquinazoline by asymmetric mannich reaction and chiral recognition. Adv Synth Catal 350:1360-1366

160. Carmine AA, Brogden RN, Heel RC, Speight TM, Avery GS (1982) Trifluridine: a review of its antiviral activity and therapeutic use in the topical treatment of viral eye infections. Drugs 23:329-353

161. Prusoff WH, Mancini WR, Lin TS, Lee JJ, Siegel SA, Otto MJ (1984) Physical and biological consequences of incorporation of antiviral agents into virus DNA. Antivir Res 4:303-315

162. Japan Pharmaceutical Information Center (JAPIC) clinical trials information http://www. clinicaltrials.jp. Accessed 16 Jan 2013 
163. Furuta Y, Takahashi K, Shiraki K, Sakamoto K, Smee DF, Barnard DL, Gowen BB, Julander JG, Morrey JD (2009) T-705 (favipiravir) and related compounds: novel broad-spectrum inhibitors of RNA viral infections. Antivir Res 82:95-102

164. Furuta Y, Takahashi K, Kuno-Maekawa M, Sangawa H, Uehara S, Kozaki K, Nomura N, Egawa H, Shiraki K (2005) Mechanism of action of T-705 against influenza virus. Antimicrob Agents Chemother 49:981-986

165. Furuta Y, Egawa H, Nomura N (2002) Nitrogen-containing heterocyclic carboxamide derivatives or salts thereof and antiviral agents comprising the same. US 2002013316

166. Egawa H, Furuta Y, Sugita J, Uehara S, Hamamoto S, Yonezawa K (2003) Novel pyrazine derivatives or salts thereof, pharmaceutical composition containing the same, and production intermediates thereof. US 2003130213

167. Takamatsu T, Yonezawa K (2010) Organic amine salt of 6-fluoro-3-hydroxy-2pyrazinecarbonitrile and method for producing the same. EP 2192117

168. Hara T, Norimatsu N, Kurushima H, Kano T (2011) Method for producing dichloropyrazine derivative. US 2011275817

169. News in brief. Antibiotic R\&D gets a dose of funding (2012) Nat Rev Drug Discov 11:507

170. Aubart K, Zalacain M (2006) Method for producing dichloropyrazine derivative. Prog Med Chem 44:110-143

171. Clements JM, Beckett RP, Brown A, Gr C, Lobell M, Palan S, Thomas W, Whittaker M, Wood S, Salama S, Baker PJ, Rodgers HF, Barynin V, Rice DW, Hunter MG (2001) Antibiotic activity and characterization of BB-3497, a novel peptide deformylase inhibitor. Antimicrob Agents Chemother 45:563-570

172. Qin D, Norton B, Liao X, Knox AN, Fang Y, Lee J, Dreabit JC, Christensen SB, Benowitz AB, Aubart KM (2009) Peptide deformylase inhibitors. WO 2009061879

173. Vermes A, Guchelaar HJ, Dankert J (2000) Flucytosine: a review of its pharmacology, clinical indications, pharmacokinetics, toxicity and drug interactions. J Antimicrob Chemother 46:171-179

174. Thompson GR, Lewis JS (2010) II pharmacology and clinical use of voriconazole. Expert Opin Drug Metab Toxicol 6:83-94

175. Johnson LB, Kauffman CA (2003) Voriconazole: a new triazole antifungal agent. Rev Anti Infect Agents 36:630-637

176. Walsh T, Pappas P, Winston D, Lazarus H, Petersen F, Raffalli J, Yanovich S, Stiff P, Greenberg R, Donowitz G, Schuster M, Reboli A, Wingard J, Arndt C, Reinhardt J, Hadley S, Finberg R, Laverdière M, Perfect J, Garber G, Fioritoni G, Anaissie E, Lee J (2002) Voriconazole compared with liposomal amphotericin B for empirical antifungal therapy in patients with neutropenia and persistent fever. N Engl J Med 346:225-234

177. Verweij PE, Mellado E, Melchers WJ (2007) Multiple-triazole-resistant aspergillosis. N Engl J Med 356:1481-1483

178. Baasner B, Klauke E (1987) Process for the preparation of 5-fluorocytosine. US 4703121

179. Robins MJ, MacCoss M, Naik SR, Ramani GJ (1976) Nucleic acid related compounds. 21. Direct fluorination of uracil and cytosine bases and nucleosides using trifluoromethyl hypofluorite. Mechanism, stereochemistry, and synthetic applications. Am Chem Soc 98:7381-7389

180. Robins MJ, Naik SR (1972) A direct synthesis of 5-fluorocytosine and its nucleosides using trifluoromethyl hypofluorite. J Chem Soc Chem Commun 1:18-19

181. Meinert H, Groß U, Rüdiger S (1984) Über synthesen von difluoraminopyrimidinen. J Fluor Chem 24:355-362

182. Takahara T (1984) Process for preparing 5-fluorocytosine salt. US 4473691

183. Ray SJ, Richardson K (1994) Triazole antifungal agents. US 5278175

184. Dickinson RP, Bell AS, Hitchcock CA, Narayanaswami S, Ray SJ, Richardson K, Troke PF (1996) Novel antifungal 2-aryl-1-(1H-1,2,4-triazol-1-yl)butan-2-ol derivatives with high activity against. Bioorg Med Chem Lett 6:2031-2036

185. D'Souza FP, Yadav PR, Sanganabhatla S, Khan MA (2011) Process for the preparation of voriconazole. US 2011312977 
186. Sundaram V, Uppala VBR, Akundi SP, Muvva V, Chitta V, Donthula A, Kharkar MR, Devarakonda SN, Peddireddy SR (2006) Process for preparing voriconazole. WO 2006065726

187. Satyanarayana RM, Nagaraju C, Kodanda Ramprasad A (2007) Improved process for the preparation of $(2 R, 3 S)$-2-(2,4-difluorophenyl)-3-(5-fluoropyrimidin-4-yl)-1-(1H-1,2,4triazol-1-yl)butan-2-ol (Voriconazole). WO 2007013096

188. Ramakrishnan A, Bhingolikar V, Naidu N (2009) Improved process for the preparation of (2R,3S)-2-(2,4-difluorophenyl)-3-(5-fluoropyrimidin-4-yl)-1-(1H-1,2,4-triazol-1-yl)butan2-ol. WO 2009084029

189. D’Souza FP, Premkumar RY, Shankar S, Mubeen AK (2010) Process for the preparation of voriconazole. WO 2010095145

190. Synthron BV, Overeem A, Zhu J (2011) A process for making voriconazole. WO 2011110198

191. Butters M, Pettman AJ, Harrison JA (2003) Preparation of triazoles by organometallic addition to ketones and intermediates therefor. US 6586594

192. Maheshwari N, Medhane RR, Prasad M, Arora SK (2011) An improved process for the preparation of voriconazole and intermediates thereof. WO 2012114273

193. Heggelund A, Undheim K (2009) Process for the production of voriconazole. WO 2009024214

194. Moon YH, Lee MS, Yoo JH, Kim JS, Kim HK, Choi CJ, Chang YK, Lee GS (2009) For preparing voriconazole. WO 2009020323

195. Choi OK, Park Y, Lee JK, Kim JH, Tan HK (2012) Intermediates of voriconazole and preparation method of voriconazole using the same. EP 2444398

196. Kwon HC, Rho MD, Cha KH (2011) Process for preparing voriconazole by using new intermediates. WO 2011096697

197. Ramakrishnan A, Kapkoti GS, Dehury SK (2011) A novel process to manufacture (2R,3S)-2(2,4-difluorophenyl)-3-(5-fluoropyrimidin-4-yl)-1-(1H-1,2,4-triazol-1-yl)butan-2-ol. WO 2011045807

198. Allen RC (1983) Section VII. Worldwide market introductions. In: Bailey DM (ed) Annual reports in medicinal chemistry, vol 19. Academic Press Inc., New York

199. Miller RL (2002) The encyclopedia of addictive drugs. Greenwood Press, Westport

200. Ochiai T, Ishida R (1981) Pharmacological studies on 6-amino-2-fluoromethyl-3-(o-tolyl)4(3H)-quinazolinone (afloqualone), a new centrally acting muscle relaxant (I). Jpn J Pharmacol 31:491-501

201. Tani J, Yamada Y, Oine T, Ochiai T, Ishida R, Inoue I (1979) Studies on biologically active halogenated compounds. 1. Synthesis and central nervous system depressant activity of 2-(fluoromethyl)-3-aryl-4(3H)-quinazolinone derivatives. J Med Chem 22:95-99

202. Inoue I, Oine T, Yamada Y, Tani J, Ishida R, Ochiai T (1976) 2-fluoromethyl-3-o-tolyl-6amino-4(3H)-quinazolinone. US 3966731

203. Vanecek SA, Essman WD, Taylor DP, Woods JH (1998) Discriminative stimulus characteristics of BMY 14802 in the pigeon. J Pharmacol Exp Ther 284:1-9

204. Taylor DP, Eison MS, Moon SL, Schlemmer RF Jr, Shukla UA, VanderMaelen CP, Yocca FD, Gallant DJ, Behling SH, Boissard CG, Braselton JP, Davis HH Jr, Duquette MN, Lamy RC, Libera JM, Ryan E, Wright RN (1993) A role for sigma binding in the antipsychotic profile of BMY 14802. NIDA Res Monogr 133:125-157

205. Weiner I, Traub A, Rawlins JN, Smith AD, Feldon J (1995) The sigma ligand BMY-14802 as a potential antipsychotic: evidence from the latent inhibition model in rats. Behav Pharmacol 6:46-54

206. Gewirtz GR, Gorman JM, Volavka J, Macaluso J (1994) BMY 14802, a sigma receptor ligand for the treatment of schizophrenia. Neuropsychopharmacology 10:37-40

207. Paquette MA, Foley K, Brudney EG, Meshul CK, Johnson SW, Berger SP (2009) The sigma-1 antagonist BMY-14802 inhibits $L$-DOPA-induced abnormal involuntary movements by a WAY-100635-sensitive mechanism. Psychopharmacology 204:743-754

208. Unger L, Garcia-Ladona F, Wermet W, Sokoloff P, Gross G (2002) In vitro characterization of the selective dopamine D3 receptor antagonist A-437203. 32th annual meeting, society of neuroscience, Orlando 
209. Zhang M, Ballard ME, Kohlhaas KL, Browman KE, Jongen-Rêlo AL, Unger LV, Fox GB, Gross G, Decker MW, Drescher KU, Rueter LE (2006) Effect of dopamine D3 antagonists on PPI in DBA/2J mice or PPI deficit induced by neonatal ventral hippocampal lesions in rats. Neuropsychopharmacology 31:1382-1392

210. Redden L, Rendenbach-Mueller B, Abi-Saab WM, Katz DA, Goenjian A, Robieson WZ, Wang Y, Goss SL, Greco N 4th, Saltarelli MD (2011) A double-blind, randomized, placebocontrolled study of the dopamine D3 receptor antagonist ABT-925 in patients with acute schizophrenia. J Clin Psychopharmacol 31:221-225

211. Gross G, Wicke K, Drescher KU (2013) Dopamine D3 receptor antagonism - still a therapeutic option for the treatment of schizophrenia. Naunyn-Schmiedeberg's Arch Pharmacol 13:155

212. Mailman RB, Murthy V (2010) Third generation antipsychotic drugs: partial agonism or receptor functional selectivity. Curr Pharm Des 16:488-501

213. Langlois X, Megens A, Lavreysen H, Atack J, Cik M, te Riele P, Peeters L, Wouters R, Vermeire J, Hendrickx H, Macdonald G, De Bruyn M (2012) Pharmacology of JNJ37822681, a specific and fast-dissociating D2 antagonist for the treatment of schizophrenia. J Pharmacol Exp Ther 342:91-105

214. Schmidt ME, Kent JM, Daly E, Janssens L, Van Osselaer N, Hüsken G, Anghelescu IG, Van Nueten L (2012) A double-blind, randomized, placebo-controlled study with JNJ37822681 , a novel, highly selective, fast dissociating D2 receptor antagonist in the treatment of acute exacerbation of schizophrenia. Eur Neuropsychopharmacol 22:721-733

215. Dextraze P, Yevich JP (1991) Agents for treatment of brain ischemia. US 4994460

216. Yevich J, Lobeck WG Jr (1986) Antipsychotic 1-fluorophenylbutyl-4-(2-pyrimidinyl)piperazine derivatives. US 4605655

217. Yevich JP, New JS, Lobeck WG, Dextraze P, Bernstein E, Taylor DP, Yocca FD, Eison MS, Temple DL Jr (1992) Synthesis and biological characterization of $\alpha$-(4-fluorophenyl)-4-(5fluoro-2-pyrimidinyl)-1-piperazinebutanol and analogues as potential atypical antipsychotic agents. J Med Chem 35:4516-4525

218. Hanson RL, Banerjee A, Comezoglu FT, Mirfakhrae KD, Patel RN, Szarka LJ (1994) Resolution of $\alpha$-(4-fluorophenyl)-4-(5-fluoro-2-pyrimidinyl)-1-piperazinebutanol (BMS 181100) and $\alpha$-(3-chloropropyl)-4-fluorobenzenemethanol using lipase-catalyzed acetylation or hydrolysis. Tetrahedron Asymmetry 5:1925-1934

219. Jaen JC, Caprathe BW, Pugsley TA, Wise LD, Akunne H (1993) Evaluation of the effects of the enantiomers of reduced haloperidol, azaperol, and related 4-amino-1-arylbutanols on dopamine and $\sigma$ receptors. J Med Chem 36:3929-3936

220. Ohkuma T, Ishii D, Takeno H, Noyori R (2000) Asymmetric hydrogenation of amino ketones using chiral $\mathrm{RuCl}_{2}$ (diphosphine)(1,2-diamine) complexes. J Am Chem Soc 122:6510-6511

221. Hoger T, Starck D, Treiber H-J, Schaefer B, Koser S, Thyes M, Blank S (2002) 2-\{3-[4-(2-t-Butyl-6-trifluoromethyl-4-pyrimidinyl)-1- piperazinyl] propylthio\}-4pyrimidinol fumarate. US 2002143179

222. De Bruyn MFL, Macdonald GJ, Kennis LEJ, Langlois XJM, Van den Keybus FAM, Van Roosbroeck YEM (2007) Piperidin-4-yl-pyridazin-3-ylamine derivatives as fast dissociating dopamine 2 receptor antagonists. WO 2007048779

223. Gribkoff VK, Bauman LA, VanderMaelen CP (1990) A 1-heteroaryl-4-piperidinyl-methyl pyrrolidinone, BMY 21502, delays the decay of hippocampal synaptic potentiation in vitro. Neuropharmacology 29:1001-1009

224. Fitten LJ, Perryman KM, Hanna JA, Menon MK (1990) Effect of BMY 21502 on acquisition of shape discrimination and memory retention in monkey. Pharmacol Biochem Behav 35:553-556

225. Woodruff-Pak DS, Sasse DK, Coffin JM, Haunton-Kreps M, Moon SL (1991) Effect of BMY 21502 on classical conditioning of the eyeblink response in young and older rabbits. Ann N Y Acad Sci 640:284-289

226. Means LW, Comer TR, Moore R (1991) BMY 21502 and piracetam facilitate performance of two-choice win-stay water-escape in normal rats. J Neural Transm Gen Sect 85:109-116 
227. Lindner MD, Gribkoff VK (1992) Effects of oral BMY 21502 on Morris water task performance in 16-18 month old F-344 rats. Psychopharmacology 107:485-488

228. Amano M, Goto A, Takahashi N, Hasegawa T, Nabeshima T (1993) Effects of BMY-21502 on anoxia in mice. Jpn J Pharmacol 61:157-163

229. Shrotriya RC, Cutler NR, Sramek JJ, Veroff AE, Hironaka DY (1996) Efficacy and safety of BMY 21502 in Alzheimer disease. Ann Pharmacother 30:1376-1380

230. Cutler NR, Shrotriya RC, Sramek JJ, Veroff AE, Seifert RD, Reich LA, Hironaka DY (1993) The use of the computerized neuropsychological test battery (CNTB) in an efficacy and safety trial of BMY 21,502 in Alzheimer's disease. Ann N Y Acad Sci 695:332-336

231. Madding GD, Minielli JL, Mattson RJ (1990) Process for large-scale production of BMY 21502. US 4963678

232. Mattson RJ, Yevich JP, Eison MS (1989) Cerebral function enhancing diazinylpiperidine derivatives. US Patent 4826843

233. Gonzãles JE, Termin AP, Wilson DM (2006) Small molecule blockers of voltage-gates sodium channels. In: Triggle DJ, Gopalakrishnan M, Rampe D, Zheng W (eds) Voltage-gated ion channels as drug targets. Wiley-WCH Verlag, Weinheim

234. Yarov-Yarovoy V, Brown J, Sharp EM, Clare JJ, Scheuer T, Catterall WA (2001) Molecular determinants of voltage-dependent gating and binding of pore-blocking drugs in transmembrane segment IIIS6 of the $\mathrm{Na}^{+}$channel $\alpha$ subunit. J Biol Chem 276:20-27

235. Wallace MS, Rowbotham M, Bennett GJ, Jensen TS, Pladna R, Quessy S (2002) A multicenter, double-blind, randomized, placebo-controlled crossover evaluation of a short course of BW-4030W92 in patients with chronic neuropathic pain. J Pain 3:227-233

236. Giblin GM, O’Shaughnessy CT, Naylor A, Mitchell WL, Eatherton AJ, Slingsby BP, Rawlings DA, Goldsmith P, Brown AJ, Haslam CP, Clayton NM, Wilson AW, Chessell IP, Wittington AR, Green R (2007) Discovery of 2-[(2,4-dichlorophenyl)amino]- $N$-[(tetrahydro2H-pyran-4-yl)methyl]-4-(trifluoromethyl)-5-pyrimidinecarboxamide, a selective CB2 receptor agonist for the treatment of inflammatory pain. J Med Chem 50:2597-2600

237. Ostenfeld T, Price J, Albanese M, Bullman J, Guillard F, Meyer I, Leeson R, Costantin C, Ziviani L, Nocini PF, Milleri S (2011) A randomized, controlled study to investigate the analgesic efficacy of single doses of the cannabinoid receptor-2 agonist GW842166, ibuprofen or placebo in patients with acute pain following third molar tooth extraction. Clin J Pain 27:668-676

238. Nobbs MS, Rodgers SJ (2000) Optically active phenyl pyrimidine derivatives as analgesic agents. US 6124308

239. Eatherton AJ, Giblin GMP, Green RH, Mitchell WL, Naylor A, Rawlings DA, Slingsby BP, Whittington AR (2004) Pyrimidine derivatives and their use as CB2 modulators. WO 2004018433

240. Brown AJ, Connor HE, Eatherton AJ, Giblin GMP, Green RH, Jandu KS, Knowles RG, Mitchell WL, Naylor A, O’Shaughnessy CT, Palombi G, Rawlings DA, Slingsby BP, Tralau-Stewart CJ, Whittington AR, Williamson RA (2005) Combination of CB2 modulators and PDE4 inhibitors for use in medicine. WO 2005074939

241. Scott DL (2011) Role of spleen tyrosine kinase inhibitors in the management of rheumatoid arthritis. Drugs 71:1121-1132

242. Podolanczuk A, Lazarus AH, Crow AR, Grossbard E, Bussel JB (2009) Of mice and men: an open-label pilot study for treatment of immune thrombocytopenic purpura by an inhibitor of Syk. Blood 113:3154-3160

243. Bajpai M (2009) Fostamatinib, a Syk inhibitor prodrug for the treatment of inflammatory diseases. Drugs 12:174-185

244. Morales-Torres $\mathbf{J}$ (2012) The status of fostamatinib in the treatment of rheumatoid arthritis. Expert Rev Clin Immunol 8:609-615

245. Liu Y, Hu Y, Liu T (2012) Recent advances in non-peptidomimetic dipeptidyl peptidase 4 inhibitors: medicinal chemistry and preclinical aspects. Curr Med Chem 19:3982-3999

246. Noh YH, Lim HS, Jin SJ, Kim MJ, Kim YH, Sung HR, Choi HY, Bae KS (2012) Effects of ketoconazole and rifampicin on the pharmacokinetics of gemigliptin, a dipeptidyl peptidase- 
IV inhibitor: a crossover drug-drug interaction study in healthy male Korean volunteers. Clin Ther 34:1182-1194

247. Irons BK, Weis JM, Stapleton MR, Edwards KL (2012) An update in incretin-based therapy: a focus on dipeptidyl peptidase 4 inhibitors. Curr Diabetes Rev 8:169-182

248. Yang SJ, Min KW, Gupta SK, Park JY, Shivane VK, Pitale SU, Agarwal PK, Sosale A, Gandhi P, Dharmalingam M, Mohan V, Mahesh U, Kim DM, Kim YS, Kim JA, Kim PK, Baik SH (2012) A multicentre, multinational, randomized, placebo-controlled, double-blind, phase 3 trial to evaluate the efficacy and safety of gemigliptin (LC15-0444) in patients with type 2 diabetes. Diabetes Obes Metab 15:410-416. doi:10.1111/dom.12042

249. Rhee E, Lee W, Min K, Shivane VK, Sosale AR, Jang H, Chung C, Nam-Goong I, Kim J, Kim S (2013) Efficacy and safety of the dipeptidyl peptidase-4 inhibitor gemigliptin compared with sitagliptin added to ongoing metformin therapy in patients with type 2 diabetes inadequately controlled with metformin alone. Diabetes Obes Metab 15:523-530. doi:10.1111/dom.12060

250. Bataller R, Brenner DA (2005) Liver fibrosis. J Clin Invest 115:209-218

251. Wada J, Makino H (2013) Inflammation and the pathogenesis of diabetic nephropathy. Clin Sci 124:139-152

252. Devraj RV, Huang W, Hughes RO, Rogier DJ Jr, Trujillo JI, Turner SR (2010) 3-aminocyclopentanecarboxamides as chemokine receptor modulators. WO 2010061329

253. Zhao Q (2010) Dual targeting of CCR2 and CCR5: therapeutic potential for immunologic and cardiovascular diseases. J Leukoc Biol 88:41-55

254. Nakajima K, Tanaka Y, Nomiyama T, Ogihara T, Piao L, Sakai K, Onuma T, Kawamori R (2002) Chemokine receptor genotype is associated with diabetic nephropathy in Japanese with type 2 diabetes. Diabetes 51:238-242

255. Lee C-S, Koh JS, Koo KD, Kim GT, Kim K-H, Hong SY, Kim S, Kim M-J, Yim HJ, Lim D, Kim HJ, Han HO, Bu SC, Kwon OH, Kim SH, Hur G-C, Kim JY, Yeom Z-H, Yeo D-J (2006) Dipeptidyl peptidase-IV inhibiting compounds, methods of preparing the same, and pharmaceutical compositions containing the same as an active agent. WO 2006104356

256. Theororidis G (2006) Fluorine-containing agrochemicals: an overview of recent developments. In: Tressaud A (ed) Fluorine and the environment: agrochemicals, archaeology, green chemistry \& water. Elsevier BV, Amsterdam/Boston

257. Hong W (2009) Agricultural products based on fluorinated heterocyclic compounds. In: Petrov VA (ed) Fluorinated heterocyclic compounds: synthesis, chemistry, and applications. Wiley, Hoboken

258. Appleby AP (2005) A history of weed control in the United States and Canada - a sequel. Weed Sci 53:762-768

259. Ware GW, Whitacre DM (2004) The pesticide book, 6th edn. MeisterPro Information Resources, Willoughby

260. Grossmann K, Hutzler J, Caspar G, Kwiatkowski J, Brommer CL (2011) Advanced technologies for parasitic weed control. Weed Sci 59:290-294

261. Hao GF, Zuo Y, Yang SG, Yang GF (2011) Protoporphyrinogen oxidase inhibitor: an ideal target for herbicide discovery. Chimia 65:961-969

262. Pesticide properties database (PPDB) http://sitem.herts.ac.uk/aeru/projects/ppdb/index.htm. Accessed 20 Feb 2013

263. Konz MJ, Wendt HR, Cullen TG, Tenhuisen KL, Fryszman OM (1998) Synthesis and chemistry of agrochemicals V. In: Baker DR, Fenyes JG, Basarab GS, Hunt DA (eds) ACS symposium series 686, Washington, DC

264. Suchy M, Winternitz P, Zeller M (1993) Herbicidal 3-aryluracils. US 5183492

265. Sting AR (2001) Process for the production of 3-aryl-uracils. US 6207830

266. Wenger J, Winternitz P, Zeller M (1990) Heterocyclic compounds. US 4941909

267. Theodoridis G, Bahr JT, Crawford S, Dugan B, Hotzman FW, Maravetz LL, Sehgel S, Suarez DP (2002) Synthesis and chemistry of agrochemicals VI. In: Baker DR, Fenyes JG, Lahm GP, Selby TP, Stevenson TM (eds). ACS symposium series 800, Washington, DC 
268. Pleschke A, Schmidt T, Gebhardt J, Loehr S, Keil M, Wevers JH (2010) Method for producing sulfonic acid diamides. US2010/222586

269. Katayama T, Kawamura S, Sanemitsu Y, Mine Y (2000) Pyridazin-3-one derivatives, their use, and intermediates for their production. US 6090753

270. Furukawa T (2000) Production of pyridazine herbicides. US 6156891

271. Mito N (2001) Herbicidal composition. US 6218338

272. Syngenta official website http://www.syngenta.com. Accessed 21 Feb 2013

273. Dow AgroSciences official website http://www.dowagro.com. Accessed 21 Feb 2013

274. Duggleby RG, McCourt JA, Guddat LW (2008) Structure and mechanism of inhibition of plant acetohydroxyacid synthase. Plant Physiol Biochem 46:309-324

275. McCourt JA, Duggleby RG (2006) Acetohydroxyacid synthase and its role in the biosynthetic pathway for branched-chain amino acids. Amino Acids 31:173-210

276. U. S. environmental protection agency official site www.epa.gov. Accessed 21 Feb 2013

277. Bailey WA, Wilcut JW, Jordan DL, Swann CW, Langston VB (1999) Weed management in peanut (Arachis hypogaea) with diclosulam preemergence. Weed Technol 13:450-456

278. Van Heertum JC, Gerwick IBC, Kleschick WA, Johnson TC (1992) Herbicidal alkoxy-1,2,4triazolo[1,5-c]pyrimidine-2-sulfonamides. US 5163995

279. Ringer JW, Pearson DL, Scott CA, Wallin AP (1998) $N$-arylsulfilimine compounds and their use as catalysts in the preparation of $N$-arylarylsulfonamide compounds. WO 9821178

280. Pearson DL, Adaway TJ (1999) Preparation of $N$-arylarylsulfonamide compounds. WO 9937650

281. Orvik JA, Shiang D (1995) 2-alkoxy-4-hydrazinopyrimidine compounds. US5461153

282. Pearson DL, Tai JJ, Adaway TJ (2000) Process for heterocyclic sulfonyl chloride compounds. US6162915

283. Pearson DL, Adaway TJ (2001) Preparation of N-arylarylsulfonamide compounds. EP1066289

284. Wang J-L, Liu D-C, Yin Y-P (2009) Synthesis of 2-((((4,6-bis(difluoromethoxy)-2pyrimidinyl)amino)carbonyl)amino)sulfonyl)benzoic acid methyl ester (Primisulfuron). Yingyong Huaxue 26:486

285. Marčić D, Perić P, Milenković S (2011) Acaricides - biological profiles, effects and uses in modern crop protection. In: Stoytcheva M (ed) Pesticides - formulations, effects, fate. InTech, Rijeka

286. Balba H (2007) Review of strobilurin fungicide chemicals. J Environ Sci Health B 42:441-451

287. Nelson DL, Cox MM (2008) Lehninger principles of biochemistry. W.H. Freeman and Co., New York

288. Leroux P (1996) Recent developments in the mode of action of fungicides. Pestic Sci 47:191-197

289. Fernández-Ortuño D, Torés JA, de Vicente A, Pérez-García A (2008) Mechanisms of resistance to QoI fungicides in phytopathogenic fungi. Int Microbiol 11:1-9

290. Heinemann U, Gayer H, Gerdes P, Krueger B-W, Gallenkamp B, Stelzer U, Marhold A, Tiemann R, Dutzmann S, Haenssler G, Stenzel K (2000) Halogen pyrimidines and its use thereof as parasite abatement means. US 6103717

291. Gayer H, Gallenkamp B, Gerdes P, Heinemann U, Krueger B-W, Lantzsch R, Seitz T, Stelzer $\mathrm{U}$ (2002) Intermediates in the preparation of 3-(1-hydroxyphenyl-1-alkoximinomethyl)dioxazines. EP 1188753

292. Kirstgen R, Oberdorf K, Schuetz F, Theobald H, Harries V (1999) 2-[(2-Alkoxy-6trifluoromethylpyrimidin-4-yl)oxymethylene]phenylacetic acid derivatives, their preparation and intermediate therefor, and use thereof. US 5935965

293. Miyazawa Y, Sagae T, Ishii H, Yazaki H, Funabora M, Takase M, Iiyoshi Y, Yamazaki S, Kawahara N (2001) Processes for producing acrylic acid derivative. EP 1142857 
294. Miyazawa Y, Sagae T, Ishii H, Yazaki H, Funabora M, Takase M, Iiyoshi Y, Yamazaki S, Kawahara N (2004) Processes for producing acrylic acid derivative. US 2004152894

295. Takase M, Miyazawa Y, Tsubokura S (2002) Methods for highly selectively $o$-alkylating amide compounds with the use of copper salts. US 6462195

296. Ghanim M, Lebedev G, Kontsedalov S, Ishaaya I (2011) Flufenerim, a novel insecticide acting on diverse insect pests: biological mode of action and biochemical aspects. J Agric Food Chem 59:2839-2844

297. Sparks TC, DeAmicis CV (2012) Inhibitors of mitochondrial electron transport: acaricides and insecticides. In: Schirmer U, Jeschke P, Witschel M (eds) Modern crop protection compounds, 2nd edn. Wiley-WCH Verlag GmbH \& Co. KGaA, Weinheim

298. Obata T, Fujii K, Ooka A, Yamanaka Y (1996) 4-phenethylaminopyrimidine derivative, and agricultural and horticultural chemical for controlling noxious organisms containing the same. US 5498612

299. Sommadossi JP, Aubert C, Cano JP, Gouveia J, Ribaud P, Mathé G (1983) Kinetics and metabolism of a new fluoropyrimidine, 5'-deoxy-5-fluorouridine. Humansю Cancer Res 43:930-933

300. Yamashita J-I, Yasumoto M, Hashimoto S (1983) Studies on tetrahydrofuryl-5-fluorouracils. IV. Mode of reaction of 5-fluorouracil with 2-acetoxytetrahydrofuran. Chem Pharm Bull 31:3872-3877

301. Uchytilova V, Holy A, Cech D, Gut J (1975) Preparation of 2-pyrimidinone and derivatives. Collect Czechoslov Chem Commun 40:2347-2352

302. Arcari JT, Bhattacharya SK, Brosius AD, Luzzio MJ, Nelson KL, Pan G, Southers JA Jr, Wishka DG, Xiao J (2007) Pyrimidine derivatives for the treatment of abnormal cell growth. WO 2007072158

303. Kudo Y, Ishida R (1989) Effects of afloqualone on vestibular nystagmus and the lateral vestibular nucleus. Jpn J Pharmacol 50:515-519

304. Furuuchi S, Otsuka M, Miura Y, Harigaya S (1983) Identification and measurement of urinary metabolites of afloqualone in man. Drug Metab Dispos 11:371-376

305. Patel RN, Hanson RL, Banerjee A, Szarka LJ (1997) Biocatalytic synthesis of some chiral drug intermediates by oxidoreductases. J Am Oil Chem Soc 74:1345-1360

306. Pierce JE, Smith DH, Eison MS, McIntosh TK (1993) The nootropic compound BMY-21502 improves spatial learning ability in brain injured rats. Brain Res 624:199-208

307. Zimmermann HW, Tacke F (2011) Modification of chemokine pathways and immune cell infiltration as a novel therapeutic approach in liver inflammation and fibrosis. Inflamm Allergy Drug Targets 10:509-536 